\title{
Ni-Based Complexes in Selective Ethylene Oligomerization Processes
}

\author{
Giyjaz E. Bekmukhamedov ${ }^{1,2, *}$, Aleksandr V. Sukhov ${ }^{1,2}$, Aidar M. Kuchkaev ${ }^{1,2}$ and \\ Dmitry G. Yakhvarov 1,2,*(D) \\ 1 Alexander Butlerov Institute of Chemistry, Kazan Federal University, 18 Kremlevskaya st., \\ 420008 Kazan, Russia; alex.suhoff@rambler.ru (A.V.S.); kuchkaev95@mail.ru (A.M.K.) \\ 2 Arbuzov Institute of Organic and Physical Chemistry, FRC Kazan Scientific Center of the Russian \\ Academy of Sciences, 8 Arbuzov st., 420088 Kazan, Russia \\ * Correspondence: gbekmouk@kpfu.ru (G.E.B.); yakhvar@iopc.ru (D.G.Y.); Tel.: +7-843-2337416 (G.E.B.); \\ Fax: +7-843-2732253 (D.G.Y.)
}

Received: 10 April 2020; Accepted: 30 April 2020; Published: 1 May 2020

\begin{abstract}
Linear alpha-olefins are widely used in the petrochemical industry and the world demand for these compounds increases annually. At present, the main method for producing linear alpha-olefins is the homogeneous catalytic ethylene oligomerization. This review presents modern nickel catalysts for this process, mainly systems for obtaining of one of the most demanded oligomer-1-butene-which is used for the production of linear low density polyethylene (LLDPE) and high density polyethylene (HDPE). The dependence of the catalytic performance on the composition and the structure of the used activated complexes, the electronic and coordination states of the nickel center was considered.
\end{abstract}

Keywords: homogeneous catalysis; ethylene oligomerization; nickel complexes; catalytic activity; selectivity; imine ligands; organophosphorus ligands; carbene ligands

\section{Introduction}

Homogeneous catalytic ethylene oligomerization is the main method for obtaining linear alpha-olefins (LAO), which are used for the production of ethylene co-polymers, synthetic fuels, lubricants, detergents, plasticizers, solvents, etc. [1].

Nickel complexes proved to be effective pre-catalysts (substances that acquire catalytic properties after activation, usually chemical) in ethylene oligomerization processes. Work in this area was initiated by the discovery in the 1950s of the "nickel effect", consisting in the fact that small amounts of nickel salts in combination with $\mathrm{AlEt}_{3}$ lead to the dimerization of ethylene [2]. Then W. Keim and co-workers developed in the late 1960s the nickel(0) complexes with P,O-ligands, which are currently industrially used in the "SHOP" ethylene oligomerization process (Shell, USA), with the total productivity of more than 1 million tons of alpha-olefins per year [3-5]. Nickel complexes are also used in other industrial processes of ethylene oligomerization ("Gulfene"/CPChem, "Linear-1"/UOP), and in dimerization of propylene and butenes ("Dimersol" and "Difasol"/IFP Energies Nouvelles; the process of Sumitomo corporation) [6-8].

In most of the listed industrial oligomerization processes, a wide fraction of alpha-olefins $\left(C_{4}-C_{20} \ldots 30\right)$ is obtained [5-7]. At the same time, 1-butene, 1-hexene, and 1-octene are the most demanded oligomers due to their use as co-monomers in ethylene polymerization [9]. Therefore, over the past two decades, there has been an increase in the number of scientific works devoted to the selective ethylene oligomerization, mainly di- and trimerization [10,11]. In addition, the largest number of works in the field of ethylene dimerization is devoted to the catalytic systems based on nickel complexes, 
which exhibit the highest activity compared to other metal complex catalysts (Pd-, Fe-, $\mathrm{Co}-$, $\mathrm{Ru}-, \mathrm{V}-$ and Ti-based) [5,7,11].

In the present work, an overview of the recent scientific literature concerning nickel-based homogeneous catalytic systems for the selective dimerization of ethylene into butenes, predominantly 1-butene, and some other demanded olefins is reported. The main attention has been paid to the dependence of the catalytic properties of activated nickel complexes on the chemical nature of ligands, the electronic and coordination state of the metal center, and oligomerization conditions.

\section{The Mechanism of Ethylene Oligomerization at the Ni-Sites}

Ethylene oligomerization at the Ni-sites is described by the mechanism (Figure 1), consisting of coordination/insertion of ethylene molecules (chain propagation), which is followed by $\beta$-H elimination of alpha-olefin (chain transfer) [12-16].

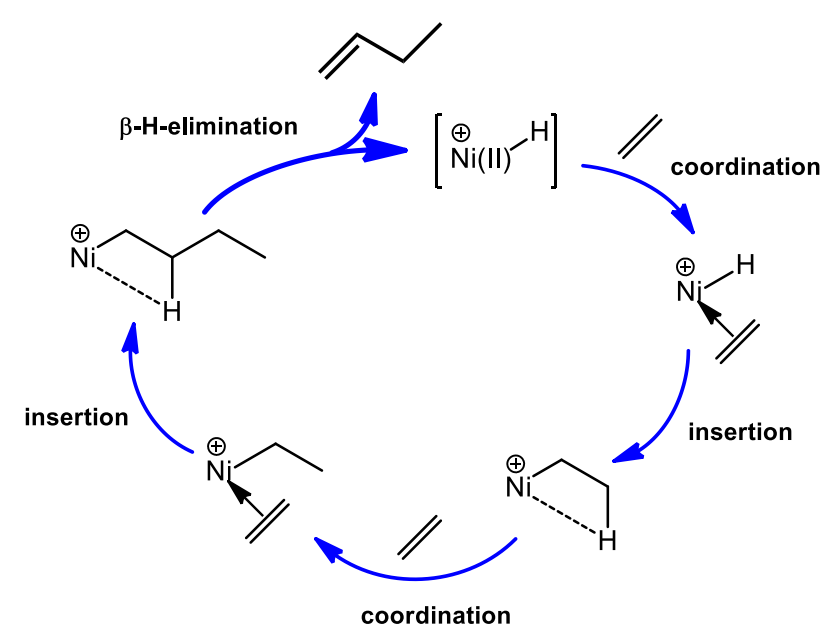

Figure 1. Mechanism of ethylene oligomerization on Ni(II) centers.

Depending on the ratio of the chain propagation rate constant $\left(\mathrm{k}_{\mathrm{P}}\right)$ and chain transfer rate constant $\left(\mathrm{k}_{\mathrm{T}}\right)$, various products are obtained: $\mathrm{k}_{\mathrm{P}}>>\mathrm{k}_{\mathrm{T}}$ - polymers, $\mathrm{k}_{\mathrm{P}} \approx \mathrm{k}_{\mathrm{T}}$-oligomers; $\mathrm{k}_{\mathrm{P}}<<\mathrm{k}_{\mathrm{T}}$-dimers [12].

\section{Nickel Complexes Bearing Imine Ligands}

Symmetric diimine nickel complexes, which were developed in the mid-1990s by M. Brookhart and co-workers, are effective pre-catalysts for ethylene oligomerization and polymerization [17]. In these complexes, bulky substituents at nitrogen atoms retard $\beta$-elimination process by blocking axial coordination centers and thus contribute to the formation of high molecular weight polymers [18]. Over the past 20 years, a large number of imine-type iron, cobalt, nickel pre-catalysts for ethylene oligomerization were developed [19-28]. The ethylene dimerization pre-catalysts are predominantly nickel complexes without bulky substituents at both nitrogen atoms (1,10-phenanthroline complexes), or at one of the nitrogen atoms [29-31]. The latter are asymmetric complexes in which the imino group is bonded to a nitrogen-containing heterocycle (imidazole, pyridine, quinoline). Typically, in these complexes in the alpha position of the $\mathrm{N}$-atom of the heterocycle there is a bulky substituent, which creates a steric hindrance at the metal center and thereby leads to a high selectivity for butenes and, in particular, for 1-butene.

\subsection{Nickel Complexes Bearing Bidentate Ligands}

\subsubsection{Nickel Complexes Bearing N,N-Ligands}

Group of W.-H. Sun developed a wide variety of imine nickel(II) complexes with five- and six-membered chelate rings, which are the analogs of Brookhart-type systems [32] and efficient 
pre-catalysts for ethylene dimerization. The developed complexes contain ligands that are derivatives of 1,10-phenanthroline, pyridine, and quinoline (Figure 2).

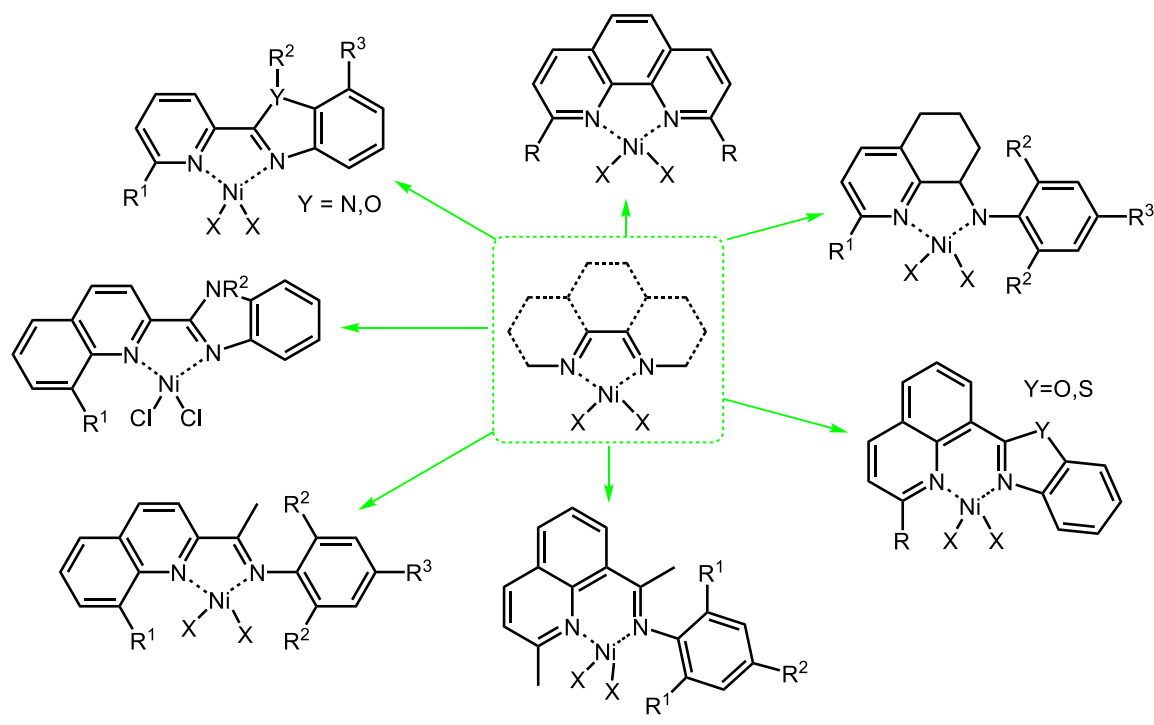

Figure 2. Nickel(II) complexes bearing N,N-ligand.

This research group studied the effect of the steric and electronic configuration of the imine ligand on the ethylene oligomerization performance of activated complexes. For the majority of these complexes, the following pattern was observed: bromide complexes are more active than chloride counterparts, due to the greater solubility of the first $[33,34]$.

Nickel(II) complexes bearing 2,9-disubstituted 1,10-phenanthroline were presented in [35] (Figure 3). The coordination geometry around the nickel atom is a distorted tetrahedron. Replacement of $\mathrm{Me}$ substituents at positions 2 and 9 of 1,10-phenanthroline by Ph ones increases oligomerization activity by a factor 1.2-2.7, while the yield of hexenes increases from 1 to $24 \%$ (please see Appendix A). Probably, in this case the same effect of bulky substituents near the metal center as for polymerization catalysts is observed: these substituents suppress $\beta$-H-elimination of 1-butene, thus favoring 1-hexene formation.
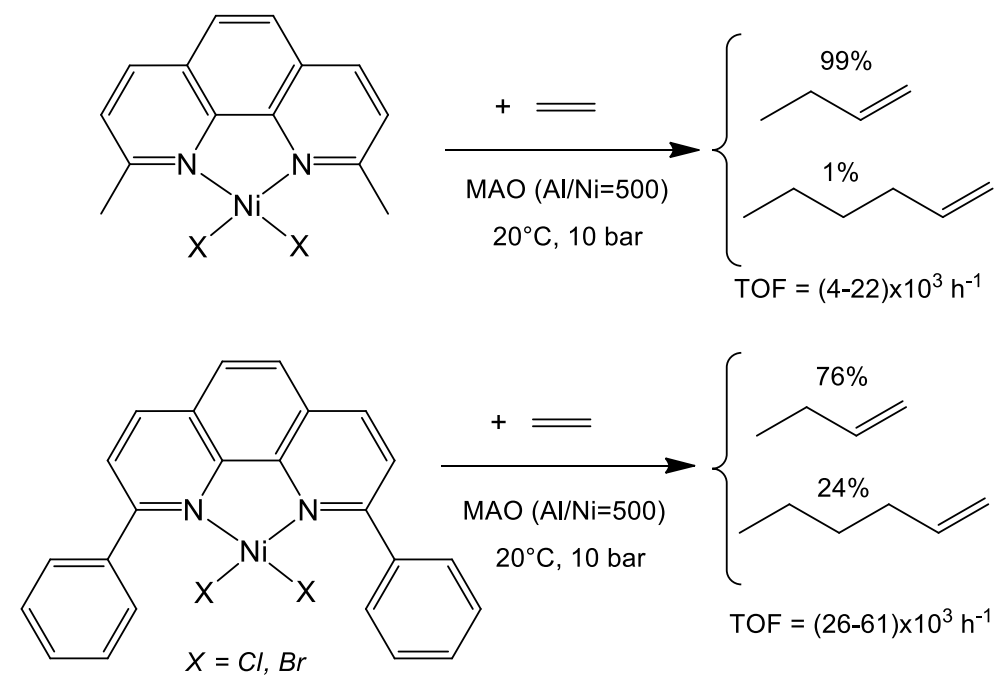

1

Figure 3. Nickel complexes with 2,9-disubstituted 1,10-phenanthroline ligands. (Please see Appendix A about presentation of the activity and selectivity data). 
Nickel complexes with benzoxazolylpyridine ligands were also used as pre-catalysts for ethylene dimerization (2a, Figure 4) [36].<smiles></smiles>

2 2a: $\mathrm{Y}=\mathrm{O} ; \mathrm{R}^{1}=\mathrm{H}, \mathrm{Me},{ }^{t} \mathrm{Bu} ; \mathrm{R}^{3}=\mathrm{H}, \mathrm{Me} ; \mathrm{X}=\mathrm{Cl}, \mathrm{Br}$;

$\mathrm{TOF}=(10-144) \times 10^{3} \mathrm{~h}^{-1} ; \mathrm{S}\left(\Sigma \mathrm{C}_{4} \mathrm{H}_{8}\right)=98-100 \%$

$\left(\mathrm{Et}_{2} \mathrm{AlCl}, \mathrm{Al} / \mathrm{Ni}=200 ; 20^{\circ} \mathrm{C}, 10\right.$ bar $)[36]$

2b: $\mathrm{Y}=\mathrm{N} ; \mathrm{R}^{1}=\mathrm{H}, \mathrm{R}^{2}=\mathrm{H}, \mathrm{Me} ; \mathrm{R}^{3}=\mathrm{Me} ; \mathrm{X}=\mathrm{Cl}$;

$\mathrm{TOF}=(6-23) \times 10^{3} \mathrm{~h}^{-1} ; \mathrm{S}\left(\Sigma \mathrm{C}_{4} \mathrm{H}_{8}\right)=89-96 \%$

$\left(\mathrm{Et}_{2} \mathrm{AlCl}, \mathrm{Al} / \mathrm{Ni}=200 ; 20^{\circ} \mathrm{C}, 20\right.$ bar) [37]

$\left(\mathrm{S}\left(\Sigma \mathrm{C}_{4} \mathrm{H}_{8}\right)\right.$ - is selectivity for butenes)

Figure 4. Ni(II) complexes ligated by benzoxazolylpyridine and benzimidazolylpyridine derivatives.

The presence of bulky substituents at benzoxazole and pyridine fragments causes high oligomerization activity. With an increase in the size of $R^{1}$ substituents at the position 5 of benzoxazole-upon transition from $\mathrm{H}$ to ${ }^{t} \mathrm{Bu}$-the activity increases from $(50-75) \times 10^{3}$ to $(99-144) \times 10^{3} \mathrm{~h}^{-1}$. It indicates that bulky substituents protect active sites [36].

As a result of the replacement of benzoxazole by benzimidazole (2b, Figure 4 ), the activity decreases from $144 \times 10^{3}$ to $23 \times 10^{3} \mathrm{~h}^{-1}$ [36,37]. Complexes with an unsubstituted benzimidazole fragment possess high activity, which may be due to the deprotonation of the $\mathrm{N}-\mathrm{H}$ group with the formation of anionic amide ligands and subsequently $\mathrm{N}-\mathrm{Al}$ particles during activation. A similar pattern is observed for the complexes with a benzimidazole fragment considered below [38].

The quinoline analog of complex 2 (3, Figure 5) after activation by $\mathrm{Et}_{2} \mathrm{AlCl}$ also catalyze the ethylene dimerization [39].<smiles>[R]C1=CC=CC2=C3C=Cc4cccc([R])c4N3[N+](Cl)(Cl)N12</smiles>

$\mathrm{R}^{1}, \mathrm{R}^{2}=\mathrm{H}, \mathrm{Me}, \mathrm{Et},{ }^{i} \mathrm{Pr}$
$\mathrm{TOF}=(55-116) \times 10^{3} \mathrm{~h}^{-1}$;

$\mathrm{S}\left(\Sigma \mathrm{C}_{4} \mathrm{H}_{8}\right)=93-94 \% ; \mathrm{S}\left(1-\mathrm{C}_{4} \mathrm{H}_{8}\right)=76-88 \%$

$\left(\mathrm{Et}_{2} \mathrm{AlCl}, \mathrm{Al} / \mathrm{Ni}=250 ; 30^{\circ} \mathrm{C} ; 10\right.$ bar $)$

$\left(\mathrm{S}\left(1-\mathrm{C}_{4} \mathrm{H}_{8}\right)\right.$ - is selectivity for 1-butene)

3

Figure 5. Ni(II) complexes bearing 2-benzoimidazol-8-alkylquinoline ligands.

A substitution of pyridine by quinoline increases the activity of the catalytic system. For example, in the case of complexes with $R^{1}=R^{2}=H, R^{3}=M e(2 \mathbf{b}$, Figure 4$)$ and with $R^{1}=M e, R^{2}=H(3$, Figure 5), the activity increases from $23 \times 10^{3}$ to $79 \times 10^{3} \mathrm{~h}^{-1}$. With a successive increase in the steric size of $\mathrm{R}^{2}$ substituent at the nitrogen atom of benzimidazole from Me to Et and ${ }^{i} \mathrm{Pr}$, the activity decreases. This is probably due to an increase in the electron-donor effect of the alkyl substituents, as they are far enough from the Ni-center to cause steric hindrances for the ethylene coordination [39].

$\mathrm{Ni}$ (II) complexes bearing derivatives of 2-(1-aryliminoethylidene)quinoline were studied (4, Figure 6a) [40]. The geometry around the Ni-center is distorted tetrahedral. The most active complex $\left(86 \times 10^{3} \mathrm{~h}^{-1}\right)$ contains Me at position of 8 of quinoline and ${ }^{i} \mathrm{Pr}$ at ortho positions of the $\mathrm{N}$-aryl ring. The nickel(II) complexes bearing hydroquinoline ligands were synthesized (5, Figure 6b) [41]. 
Replacement of Me substituent at the position 2 of the hydroquinoline fragment $\left(\mathrm{R}^{1}\right)$ by ${ }^{i} \operatorname{Pr}$ results in the reduction of activity, due to its steric and electronic influence on the Ni-center.<smiles>[R]c1cc([R])c(N2C(C)=C3C=Cc4cccc([R])c4N3[N+]2(Br)Br)c([R])c1</smiles>

$\mathrm{R}=\mathrm{Me}, \mathrm{Et}, \mathrm{i}^{\mathrm{Pr}} ; \mathrm{R}^{1}=\mathrm{Me}, \mathrm{Et}, \mathrm{iPr}, \mathrm{CH}(\mathrm{Ph})_{2}$; $\mathrm{R}^{2}=\mathrm{H}, \mathrm{Me}, \mathrm{NO}_{2}$

4

(a)

$\mathrm{TOF}=(32-86) \times 10^{3} \mathrm{~h}^{-1} ; \mathrm{S}\left(1-\mathrm{C}_{4} \mathrm{H}_{8}\right)=91-95 \%$

$\left(\mathrm{Et}_{2} \mathrm{AlCl}, \mathrm{Al} / \mathrm{Ni}=200 ; 20^{\circ} \mathrm{C}, 10\right.$ bar $)$<smiles>[R]C1=CC=C2CCCC(=C3C2[N+](Br)(Br)N3c2c([R])cc([R])cc2[R])N1Br</smiles>

$\mathrm{R}^{1}=\mathrm{Me},{ }^{\mathrm{i}} \mathrm{Pr} ; \mathrm{R}^{2}=\mathrm{Me}, \mathrm{Et},{ }^{\mathrm{i}} \mathrm{Pr} ; \mathrm{R}^{3}=\mathrm{H}, \mathrm{Me}$ 5

(b)

$\mathrm{TOF}=(6-39) \times 10^{3} \mathrm{~h}^{-1} ; \mathrm{S}\left(\Sigma \mathrm{C}_{4} \mathrm{H}_{8}\right)=100 \%$

$\left(\mathrm{Et}_{3} \mathrm{Al}_{2} \mathrm{Cl}_{3}, \mathrm{Al} / \mathrm{Ni}=200 ; 80^{\circ} \mathrm{C} ; 10\right.$ bar $)$

Figure 6. $\mathrm{Ni}(\mathrm{II})$ complexes with five-membered chelate ring, and bearing quinoline (a) and hydroquinoline (b) ligands.

In [42], the analogs of the above considered $\mathrm{Ni}^{\mathrm{iI}}$ complexes, but bearing 2-iminopyridine ligands, were presented (6, Figure 7).<smiles></smiles>

$\mathrm{X}=\mathrm{Cl}, \mathrm{Br} ; \mathrm{R}^{1}=\mathrm{Me}, \mathrm{Br} ; \mathrm{R}^{2}=\mathrm{H}, \mathrm{F}, \mathrm{CF}_{3} ; \mathrm{R}^{3}=\mathrm{H}, \mathrm{F}$;
$\mathrm{TOF}=(93-686) \times 10^{3} \mathrm{~h}^{-1} ;$

$\mathrm{S}\left(\Sigma \mathrm{C}_{4} \mathrm{H}_{8}\right)=90-100 \%$;

$\mathrm{S}\left(1-\mathrm{C}_{4} \mathrm{H}_{8}\right)=34-78 \%$ (in $\mathrm{C}_{4}$-fraction)

(MAO, $\mathrm{Al} / \mathrm{Ni}=500 ; 35^{\circ} \mathrm{C} ; 2$ bar)

$$
\mathrm{R}^{4}=\mathrm{H}, \mathrm{F}, \mathrm{Cl} ; \mathrm{R}^{5}=\mathrm{H}, \mathrm{F}
$$

\section{6}

Figure 7. $\mathrm{Ni}(\mathrm{II})$ complexes bearing 2-iminopyridine ligands.

Replacement of $\mathrm{F}$ by bulkier $\mathrm{CF}_{3}$ substituent at the ortho position of the aryl moiety $\left(\mathrm{R}^{2}\right)$ leads to an increase in activity (from $529 \times 10^{3}$ to $657 \times 10^{3} \mathrm{~h}^{-1}$ ) and a decrease in selectivity for butenes (from $98 \%$ to $90 \%$ ) as a result of the formation of oligomers with longer chain [42]. These complexes, immobilized on the surface of $\mathrm{SiO}_{2} / \mathrm{Al}_{2} \mathrm{O}_{3}$, have slightly less activity-(79-346) $\times 10^{3} \mathrm{~h}^{-1}$-and comparable selectivity for butenes (93-98\%).

Bidentate nickel(II) complexes bearing N,N-ligands, which form a six-membered chelate ring, were also considered as pre-catalysts for ethylene dimerization (Figure 8). 


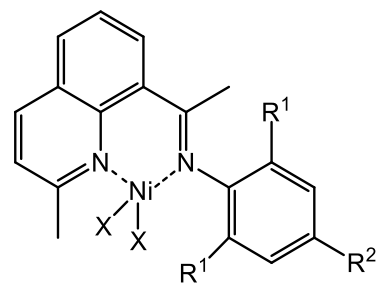

$\mathrm{R}^{1}=\mathrm{Me}, \mathrm{Et}, \mathrm{Pr} ; \mathrm{R}^{2}=\mathrm{H}, \mathrm{Me} ; \mathrm{X}=\mathrm{Cl}, \mathrm{Br}$ 7

(a)

TOF $=(4-65) \times 10^{3} \mathrm{~h}^{-1} ; \mathrm{S}\left(\Sigma \mathrm{C}_{4} \mathrm{H}_{8}\right)=87-100 \%$

$\left(\mathrm{Et}_{2} \mathrm{AlCl}, \mathrm{Al} / \mathrm{Ni}=200 ; 60{ }^{\circ} \mathrm{C} ; 10\right.$ bar $)$

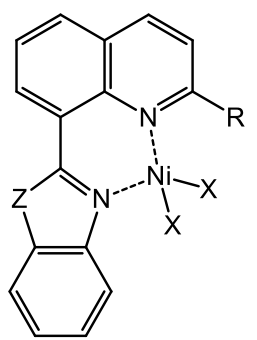

$\mathrm{R}=\mathrm{Me}, \mathrm{Et}, \mathrm{Pr} ; \mathrm{Z}=\mathrm{O}, \mathrm{S} ; \mathrm{X}=\mathrm{Cl}, \mathrm{Br}$

\section{8}

(b)

$\mathrm{TOF}=(77-139) \times 10^{3} \mathrm{~h}^{-1} ; \mathrm{S}\left(\Sigma \mathrm{C}_{4} \mathrm{H}_{8}\right)=93-99 \%$

$\left(\mathrm{Et}_{3} \mathrm{Al}_{2} \mathrm{Cl}_{3}, \mathrm{Al} / \mathrm{Ni}=600 ; 40{ }^{\circ} \mathrm{C}, 10\right.$ бар)

Figure 8. Ni(II) complexes with six-membered chelate ring, and bearing arylimino-quinoline (a), benzoxazolyl- and benzothiazolyl-quinoline (b) ligands.

In [33], nickel(II) complexes bearing arylimino-quinoline ligands were studied (7, Figure 8a). The activity increases, if the substituent at ortho positions of the arylimine fragment $\left(\mathrm{R}^{1}\right)$ is changed from Me to ${ }^{i} \mathrm{Pr}$; and the activity decreases if $\mathrm{R}^{1}$ is changed to Et. This can be explained by the rotation of the $\sigma$-bond in Et moiety, which thus reduces steric hindrances compared to Me.

Analogs of this complex with benzoxazolyl and benzothiazolyl fragment (8, Figure 8b), which exclude the possibility of rotation of the $\mathrm{Ph}$ ring at the nitrogen atom, exhibit higher activity-(138-139) $\times 10^{3} \mathrm{vs}$. $(25-57) \times 10^{3} \mathrm{~h}^{-1}$, but lower selectivity for 1-butene- $40-44 \%$ vs. $66-78 \%$. At the same time, complexes with benzothiazolyl and benzoxazolyl fragments have similar activity-129 $\times 10^{3}$ and $138 \times 10^{3} \mathrm{~h}^{-1}$, respectively [43].

Based on 1,10-phenanthroline derivatives, bis-chelate (9) and binuclear (10) nickel complexes were synthesized (Figure 9) [44].

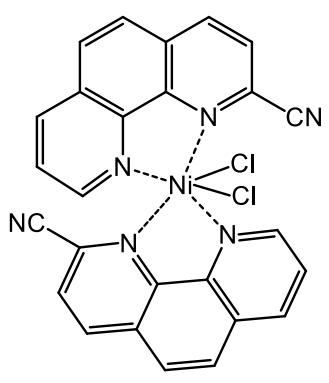

9

$\mathrm{TOF}=1.5 \times 10^{3} \mathrm{~h}^{-1}$

$\mathrm{S}\left(\Sigma_{4} \mathrm{C}_{4} \mathrm{H}_{8}\right)=89 \% ; \mathrm{S}\left(1-\mathrm{C}_{4} \mathrm{H}_{8}\right)=52 \%$

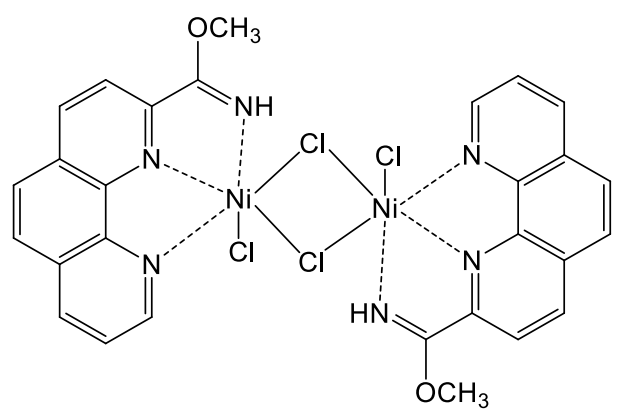

10

$\mathrm{S}\left(\Sigma \mathrm{C}_{4} \mathrm{H}_{8}\right)=83 \% ; \mathrm{S}\left(1-\mathrm{C}_{4} \mathrm{H}_{8}\right)=19 \%$

$\left(\mathrm{Et}_{2} \mathrm{AlCl}, \mathrm{Al} / \mathrm{Ni}=200 ; 25^{\circ} \mathrm{C} ; 1\right.$ bar $)$

Figure 9. Bis-chelate (9) and binuclear (10) nickel complexes ligated by 1,10-phenanthroline derivatives.

Binuclear complex $\mathbf{1 0}$ has ca. 8 times higher activity compared to bis-chelate complex $\mathbf{9}$. This may be due to the fact that two cyano-phenanthroline ligands in complex 8 occupy the space around the $\mathrm{Ni}$-center and thus hinder the coordination of ethylene [44] 


\subsubsection{Nickel Complexes Bearing N,O- and N,S-Ligands}

Casagrande and co-workers developed ether-imine-furfural nickel(II) complexes 11a-11d (Figure 10) [45].

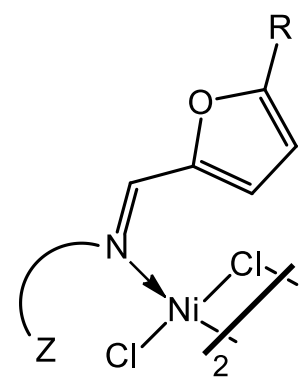

11

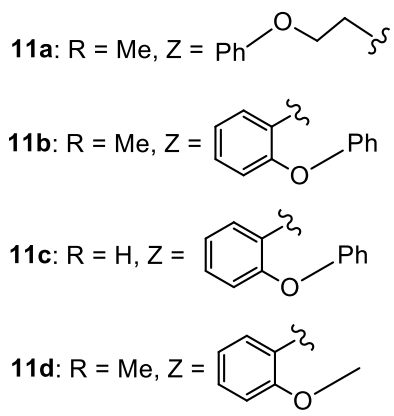

$\mathrm{TOF}=(15-22) \times 10^{3} \mathrm{~h}^{-1} ; \mathrm{S}\left(\mathrm{C}_{4} \mathrm{H}_{8}\right)=91-100 \% ; \mathrm{S}\left(1-\mathrm{C}_{4} \mathrm{H}_{8}\right)=69-90 \%$

(PMAO-IP, $\mathrm{Al} / \mathrm{Ni}=500 ; 30^{\circ} \mathrm{C} ; 20$ bar)

Figure 10. Ether-imine-furfural nickel(II) complexes.

The coordination of the oxygen-donor group to a nickel center in the activated complex promotes the formation of more stable catalytic active species. The substitution of the alkyl moiety by a more rigid Ph ring (11b) in pendant Z-group leads to an increase in activity from $22 \times 10^{3}$ to $57 \times 10^{3} \mathrm{~h}^{-1}$. A decrease in the steric hindrance of the furfural unit by changing Me at the position 5 to $\mathrm{H}$ (11c) leads to a 3-fold reduction in activity. An increase in the length of the bridge between the imine and ether donor groups by one carbon atom (11d) leads to a 4-fold decrease in activity. This phenomenon is due to the difficulty in coordination of the OMe-group to the metal center with the formation of a stable six-membered cyclic complex [45].

Depending on the co-catalyst, these complexes have different activities. Thus, after activation by polymethylaluminoxane (PMAO-IP, where IP_improved performance; $\mathrm{Al} / \mathrm{Ni}=500$ ) activity of the $11 \mathrm{~b}$ complex is $57 \times 10^{3} \mathrm{~h}^{-1}$, selectivities for butenes and 1-butene are $91 \%$ and $69 \%$, respectively. Upon transition to the methylaluminoxane (MAO) co-catalyst, the activity increases to $69 \times 10^{3} \mathrm{~h}^{-1}$, and the selectivity for butenes/1-butene almost does not change. The use of $\mathrm{Et}_{3} \mathrm{Al}_{2} \mathrm{Cl}_{3}$ is accompanied by an increase in activity to $206 \times 10^{3} \mathrm{~h}^{-1}$, while the selectivity for 1-butene decreases to $12 \%$, which is due to the heating of the reaction media (from 30 to $55-57^{\circ} \mathrm{C}$ ) because of exothermicity of oligomerization process [45]. Thus, chemical nature of the co-catalyst has a significant effect on the activity of the system due to its Lewis acidity, which is required for the dehalogenation of the complex and the formation of the metal-alkyl bond [46], as well as due to the interaction of aluminum with nickel, which prevents the decomposition of the active site as a result of $\beta$-hydride or reductive elimination $[47,48]$.

Nickel(II) complexes bearing imine-thioether ligands were tested in ethylene oligomerization (12, Figure 11) [49].<smiles>[R]N1Cc2ccccc2[SH]([R])N1Br</smiles>

$\mathrm{R}^{1}={ }^{t} \mathrm{Bu}, \mathrm{Ph} ; \mathrm{R}^{2}={ }^{\mathrm{B} u}, \mathrm{Ph},-\mathrm{C}_{6} \mathrm{H}_{4}-(p-\mathrm{OMe})$

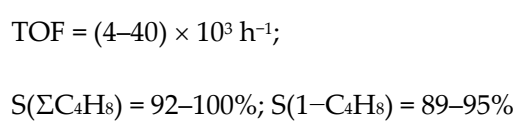

$\left(\mathrm{MAO}, \mathrm{Al} / \mathrm{Ni}=250 ; 20 \mathrm{bar}, 30^{\circ} \mathrm{C}\right)$

Figure 11. Ni(II) complexes bearing imine-thioether ligands. 
As a result of the changing of the substituent at the $\mathrm{N}$-atom from ${ }^{t} \mathrm{Bu}$ to $-\mathrm{C}_{6} \mathrm{H}_{4}-(p-\mathrm{OMe})$, the activity of complex 12 decreases from $23 \times 10^{3}$ to $4 \times 10^{3} \mathrm{~h}^{-1}$. This is due to the stabilization of the complex by this donor group, as a result of which the nitrogen atom is less labile and stronger coordinated to the metal center [49]. Substitution of $-\mathrm{C}_{6} \mathrm{H}_{4}\left(p\right.$-OMe) by Ph leads to higher activity $\left(40 \times 10^{3} \mathrm{~h}^{-1}\right)$. This may be due to the fact that the introduction of weak electron-withdrawing substituents causes greater lability of nickel-coordinated groups and, therefore, facilitates the interaction between the metal center and ethylene molecules.

In the case of the presence of ${ }^{t} \mathrm{Bu}$ at $\mathrm{N}$ - and S-atoms (Figure 11), nickel is coordinated to only one ligand and therefore has a coordination number of four (while in other cases it has two ligands and the coordination number of six). This is due to the fact that ${ }^{t} \mathrm{Bu}$ creates steric hindrances for the coordination of the second ligand, as well as suppress the $\beta$-elimination process, as can be concluded from the formation of $\alpha-C_{8}-C_{10}$-olefins (ca. $4 \%$ ). After activation, this complex has three-fold less activity compared to the analog, which contains $\mathrm{Ph}$ substituents at $\mathrm{N}$ - and $\mathrm{S}$-atoms. At the same time, the 1-butene selectivity is slightly higher ( $93 \%$ vs. $89 \%)$ [49].

\subsection{Nickel Complexes Bearing Tridentate Imine Ligands}

Group of W.-H. Sun developed a significant number of pre-catalysts for ethylene dimerization-nickel complexes bearing tridentate $\mathrm{N}, \mathrm{N}, \mathrm{N}$ - and $\mathrm{N}, \mathrm{N}, \mathrm{O}$-ligands. In these complexes, $\mathrm{N}$ - and/or O- atoms, which are coordinated to nickel, are involved in the conjugated system. Ligands can be classified as derivatives of 1,10-phenanthroline, pyridine, and quinoline (Figure 12).

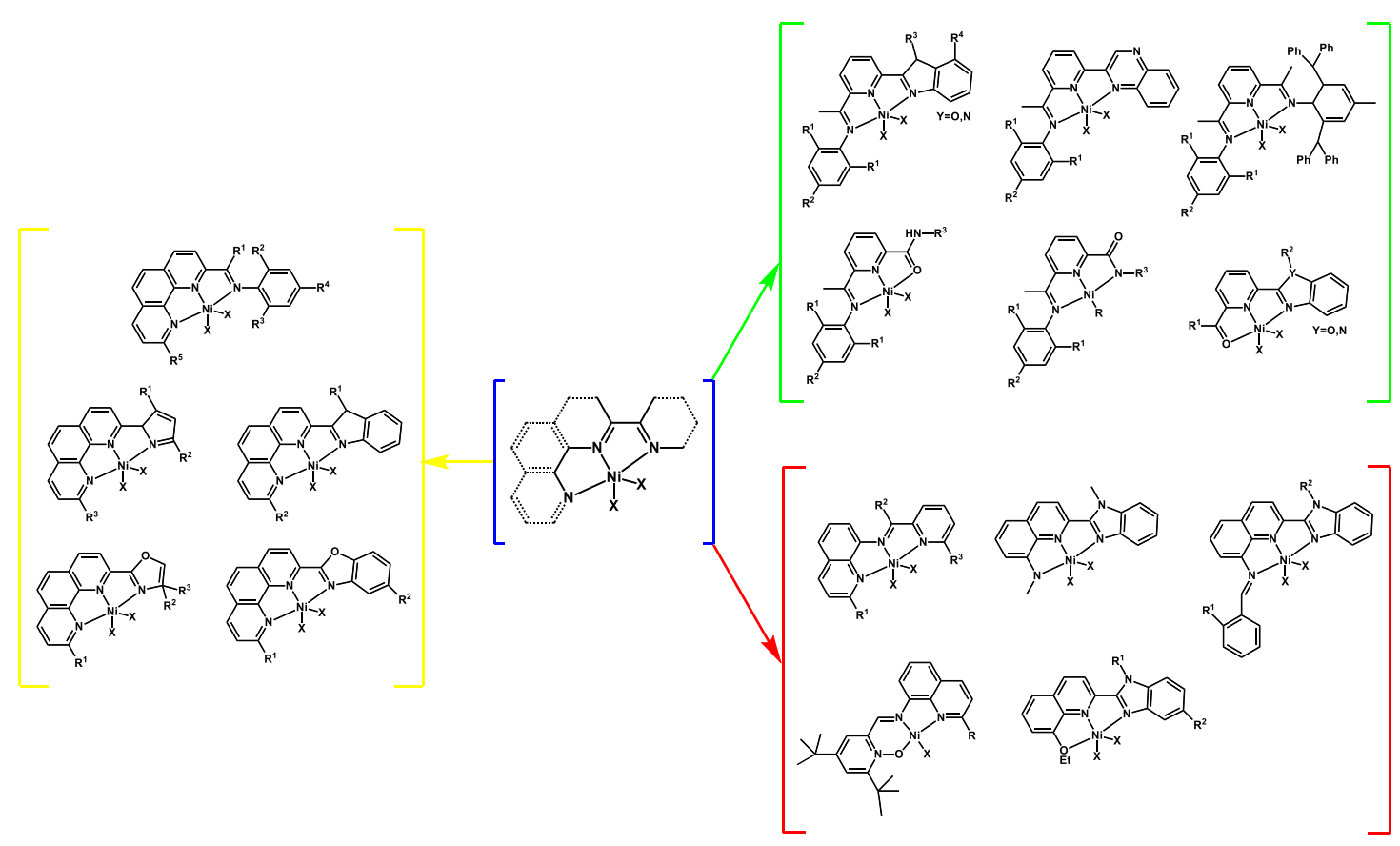

Figure 12. Nickel complexes bearing $\mathrm{N}, \mathrm{N}, \mathrm{N}$ - and $\mathrm{N}, \mathrm{N}, \mathrm{O}-$ ligands, which were developed by the group of W.-H. Sun.

\subsubsection{Nickel Complexes Bearing 1,10-Phenanthroline Ligands}

As pre-catalysts for ethylene dimerization, nickel complexes bearing tridentate $\mathrm{N}, \mathrm{N}, \mathrm{N}$-ligands based on 1,10-phenanthroline were considered, for example, complexes based on arylimino-phenanthroline ligands (13, Figure 13a) [50]. 


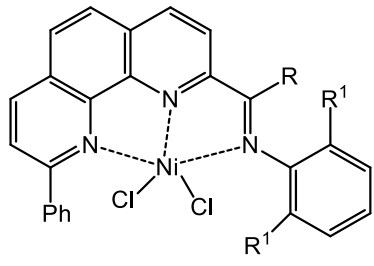

$\mathrm{R}=\mathrm{Me}, \mathrm{Ph} ; \mathrm{R}^{1}=\mathrm{Me}, \mathrm{Et}, \mathrm{Pr}$

13

(a)

$\mathrm{TOF}=(131-220) \times 10^{3} \mathrm{~h}^{-1} ; \mathrm{S}\left(\Sigma \mathrm{C}_{4} \mathrm{H}_{8}\right)=98-99 \%$

$\left(\mathrm{Et}_{2} \mathrm{AlCl}, \mathrm{Al} / \mathrm{Ni}=300 ; 30^{\circ} \mathrm{C} ; 10\right.$ bar $)$<smiles></smiles>

$\mathrm{R}^{1}=\mathrm{H}, \mathrm{Ph} ; \mathrm{R}^{2}=\mathrm{H}, \mathrm{Me},{ }^{t} \mathrm{Bu}$

15

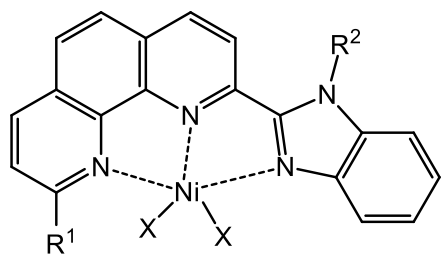

$\mathrm{R}^{1}=\mathrm{H}, \mathrm{Me} ; \mathrm{R}^{2}=\mathrm{H}, \mathrm{Me}, \mathrm{Et}, i \operatorname{Pr}, \mathrm{Bn} ; \mathrm{X}=\mathrm{Cl}, \mathrm{Br}$

\section{4}

(b)
(Et $2 \mathrm{AlCl}, \mathrm{Al} / \mathrm{Ni}=300 ; 20^{\circ} \mathrm{C} ; 30$ bar $)$

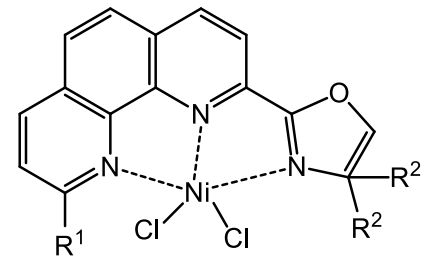

$\mathrm{R}^{1}=\mathrm{H}, \mathrm{Ph} ; \mathrm{R}^{2}=\mathrm{H}, \mathrm{Me}$

16

(c)

$$
\begin{gathered}
\mathrm{TOF}=(37-111) \times 10^{3} \mathrm{~h}^{-1} ; \mathrm{S}\left(\Sigma \mathrm{C}_{4} \mathrm{H}_{8}\right)=81-97 \% ; \mathrm{S}\left(1-\mathrm{C}_{4} \mathrm{H}_{8}\right)=44-84 \% \\
\left(\mathrm{Et}_{2} \mathrm{AlCl}, \mathrm{Al} / \mathrm{Ni}=200 ; 20{ }^{\circ} \mathrm{C} ; 10 \text { bar }\right)
\end{gathered}
$$

Figure 13. Nickel(II) complexes bearing tridentate 1,10-phenanthroline N,N,N-ligands:aryliminophenanthroline (a), benzimidazole-phenanthroline (b), oxazole- and benzoxazole-phenanthroline (c).

Phenyl-ketimine complexes are more active than methyl-ketimine counterparts (13, Figure 13a) [50]. In the case of complex 14, which contains benzimidazole fragment (Figure 13b), more rigid skeleton causes lower activity compared to complex $13-83 \times 10^{3} \mathrm{~h}^{-1}$ (30 bar) vs. $131 \times 10^{3} \mathrm{~h}^{-1}$ (10 bar), but higher selectivity for 1-butene (91\% vs. 36\%) [38].

The replacement of nitrogen in the heterocycle by oxygen (15, Figure 13c) does not significantly affect both the activity and selectivity for butenes [51]. As a result of the introduction of $\mathrm{Me}$ or ${ }^{t} \mathrm{Bu}$ substituents to the position 5 of benzoxazole or two Me to the position 4 of oxazoline, the activity decreases by 1.2-1.7 times, which is due to electron donation by alkyl groups to benzoxazole or oxazoline, followed by repulsion of the electron density to the nickel cation, accompanied by a decrease in its positive charge. Complexes with oxazoline fragment have 1.2-1.4 times higher activity compared to analogs with benzoxazole fragment, which is due to additional steric hindrances created by the benzene ring. In addition, oxazoline provides a lower electron-donor effect on the metal center than benzoxazole [51].

In the case of the complexes 8, 14, 15 and 16 (Figures $8 b$ and 13b,c) [38,51], the introduction of Me or Ph substituent $\left(\mathrm{R}^{1}\right)$ to the alpha-position relative to the $\mathrm{N}$-atom, was accompanied by a decrease in activity, which is due to steric hindrances for ethylene coordination to the metal center.

In [52], nickel(II) complexes bearing 2-pyrazolyl substituted 1,10-phenanthroline ligands were presented (17, Figure 14). 


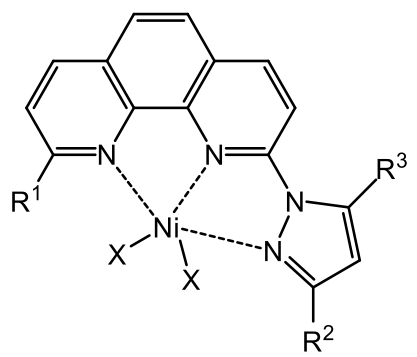

$\mathrm{X}=\mathrm{Cl}, \mathrm{Br} ; \mathrm{R}^{1}=\mathrm{H}, \mathrm{Ph}, 1$-naphthyl, Mes; $\mathrm{R}^{2}, \mathrm{R}^{3}=\mathrm{Me}, \mathrm{Ph}$

17

$\mathrm{TOF}=(1-5) \times 10^{3} \mathrm{~h}^{-1}, \mathrm{~S}\left(\Sigma \mathrm{C}_{4} \mathrm{H}_{8}\right)=89-97 \%, \mathrm{~S}\left(1-\mathrm{C}_{4} \mathrm{H}_{8}\right)=>(51-67 \%)$

$\left(\mathrm{MAO}, \mathrm{Al} / \mathrm{Ni}=1500 ; 20^{\circ} \mathrm{C} ; 1\right.$ bar)

Figure 14. Nickel(II) complexes bearing 2-pyrazolyl substituted 1,10-phenanthroline ligands.

With an increase in the size of the substituent at the position 9 of 1,10-phenanthroline fragment and substituents at the pyrazole ring, the activity increases. For example, when $\mathrm{R}^{1}$ is changed from $\mathrm{H}$ to Mes, the activity increases by 3 times, and upon changing of $\mathrm{R}^{3}$ substituent from $\mathrm{Me}$ to $\mathrm{Ph}$, the activity increases by ca. 2 times. Aryl groups as substituents can cause the conjugation effect, which stabilizes the insertion transition state and thus increases the activity. Bulkier substituents can suppress chain transfer reactions ( $\beta-\mathrm{H}$-elimination) and thus slightly increase the activity. Thus, in the presence of complexes with $\mathrm{R}^{1}=$ Mes and $\mathrm{R}^{2}=\mathrm{R}^{3}=\mathrm{Ph}$, the greatest amount of hexenes is formed. However, the increase in activity cannot be caused only by an increase in the rate of the trimerization process. It has been suggested that the reason for the increased activity is the creation of reaction channels by bulky aryl groups, which make the coordination of ethylene to the nickel-center more efficient [52].

\subsubsection{Nickel Complexes Bearing Pyridine Ligands}

As pre-catalysts for ethylene dimerization, analogs of the complexes 13-17 have been proposed, in which 1,10-phenanthroline is replaced by arylimino-pyridine (Figure 15) [53].<smiles></smiles>

$\mathrm{X}=\mathrm{Cl}, \mathrm{Br} ; \mathrm{R}^{1}=\mathrm{Me}, \mathrm{Et}, \mathrm{Pr}, \mathrm{Cl}, \mathrm{Br} ; \mathrm{R}^{2}=\mathrm{H}, \mathrm{Me}$

18

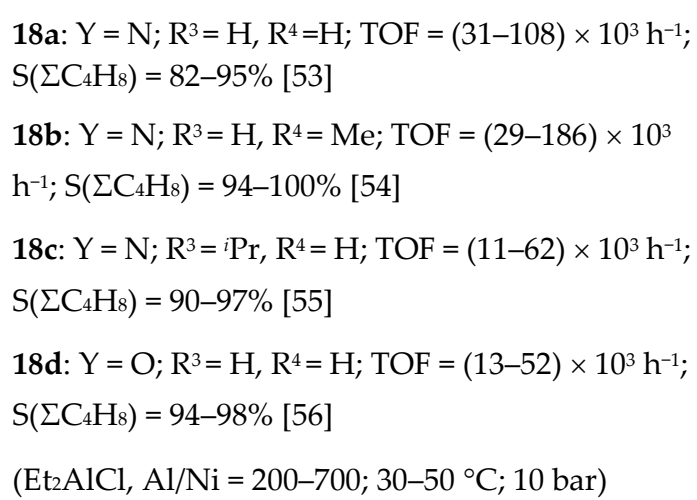

Figure 15. Nickel(II) complexes bearing arylimino-pyridine N,N,N-ligands.

These complexes have slightly lower activity and close selectivity for butenes compared to their 1,10-phenanthroline analogs 14 (Figure 13b) [38]. As a result of the introduction of Me substituent into the benzene ring of benzimidazole (18b, Figure 15), the activity increases from $57 \times 10^{3}$ to $100 \times 10^{3} \mathrm{~h}^{-1}$ [54]. This is due to an increase in the solubility of the complex with increased ligand size. The introduction of an ${ }^{i} \operatorname{Pr}$ substituent to the $\mathrm{N}$-atom of benzimidazole (18c) leads to a decrease in activity from $57 \times 10^{3}$ to $43 \times 10^{3} \mathrm{~h}^{-1}$ [55]. Upon transition from benzimidazole (18a) to benzoxazole (18d) the activity decreases from $57 \times 10^{3}$ to $13 \times 10^{3}$ with close selectivities for butenes and 1-butene- $98 \%$ and $94 \%$, respectively [56]. 
With an increase in the size of the heterocycle from five-membered to a six-membered, upon transition from benzimidazole (18, Figure 15) to quinoxaline (19, Figure 16), the activity decreases from $21 \times 10^{3}$ to $8 \times 10^{3} \mathrm{~h}^{-1}$, and the selectivity for butenes increases from $90 \%$ to $94 \%$ [57].

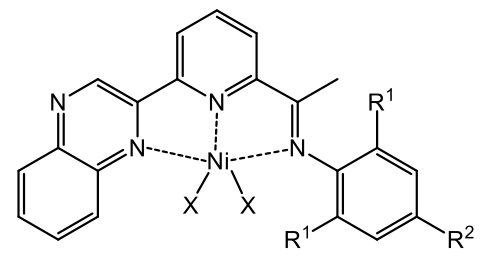

$\mathrm{X}=\mathrm{Cl}, \mathrm{Br} ; \mathrm{R}^{1}=\mathrm{Me}, \mathrm{Et},{ }^{i \mathrm{Pr}}, \mathrm{F}, \mathrm{Cl} ; \mathrm{R}^{2}=\mathrm{H}, \mathrm{Me}$
$\mathrm{TOF}=(4-25) \times 10^{3} \mathrm{~h}^{-1}, \mathrm{~S}\left(\Sigma \mathrm{C}_{4} \mathrm{H}_{8}\right)=78-99 \%$;

$\left(\mathrm{Et}_{2} \mathrm{AlCl}, \mathrm{Al} / \mathrm{Ni}=700 ; 20^{\circ} \mathrm{C} ; 10\right.$ bar $)$

19

Figure 16. Nickel(II) complexes bearing 2-quinoxalinyl-6-iminopyridine ligands.

Naphthyl complex 20, in which benzoxazole is substituted by an amide group (Figure 17a), possesses higher activity compared to the dichloride benzoxazole analog $\mathbf{1 8 d}$ (Figure 15) $-22 \times 10^{3} \mathrm{vs}$. $13 \times 10^{3} \mathrm{~h}^{-1}\left(\mathrm{Et}_{2} \mathrm{AlCl}, \mathrm{Al} / \mathrm{Ni}=200 ; 20^{\circ} \mathrm{C} ; 10 \mathrm{bar}\right)$ [58]. As a result of the changing of benzimidazole to 2,6-dibenzhydryl-4-methylphenyl (21, Figure 17b), the activity decreases, but at the same time, 1-butene selectivity remains as high [59].

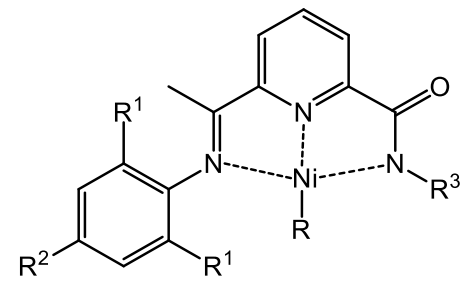

$\mathrm{R}=\mathrm{Naph} ; \mathrm{R}^{1}=\mathrm{Me} ; \mathrm{R}^{2}=\mathrm{H} ; \mathrm{R}^{3}={ }^{n} \mathrm{Bu}$

20

(a)

$\mathrm{TOF}=(0.3-2.8) \times 10^{3} \mathrm{~h}^{-1}$;

$\mathrm{S}\left(\Sigma \mathrm{C}_{4} \mathrm{H}_{8}\right)=86-96 \%$

$\left(\mathrm{Et}_{2} \mathrm{AlCl}, \mathrm{Al} / \mathrm{Ni}=200 ; 20^{\circ} \mathrm{C} ; 1\right.$ bar $)$

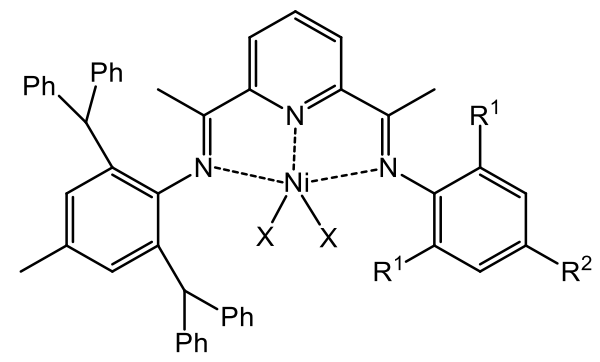

$\mathrm{X}=\mathrm{Cl}, \mathrm{Br} ; \mathrm{R}^{1}=\mathrm{Me}, \mathrm{Et}, \mathrm{Pr} ; \mathrm{R}^{2}=\mathrm{H}, \mathrm{Me}$

21

(b)

$\mathrm{TOF}=(1-15) \times 10^{3} \mathrm{~h}^{-1}$;

$\mathrm{S}\left(\Sigma \mathrm{C}_{4} \mathrm{H}_{8}\right)=93-98 \%$;

$\mathrm{C}\left(1-\mathrm{C}_{4} \mathrm{H}_{8}\right)=87-97 \%$ (in $\mathrm{C}_{4}$-fraction)

$\left(\mathrm{Et}_{3} \mathrm{Al}_{2} \mathrm{Cl}_{3}, \mathrm{Al} / \mathrm{Ni}=300 ; 40{ }^{\circ} \mathrm{C} ; 10\right.$ bar $)$

Figure 17. Nickel(II) complexes bearing arylimino-pyridine $\mathrm{N}, \mathrm{N}, \mathrm{N}$-ligands: arylimino-picolinamide (a) and bis(arylimino)-pyridine (b).

The substitution of the aryl-ethylimine fragment at the position 6 of pyridine ring by acetyl and carboethoxyl group (22, Figure 18) leads to a decrease in both activity and selectivity for butenes [37].<smiles></smiles>

22 22a: $\mathrm{R}=\mathrm{Me} ; \mathrm{TOF}=5 \times 10^{3} \mathrm{~h}^{-1} ; \mathrm{S}\left(\Sigma \mathrm{C}_{4} \mathrm{H}_{8}\right)=62 \%$

22b: $\mathrm{R}=\mathrm{EtO} ; \mathrm{TOF}=2 \times 10^{3} \mathrm{~h}^{-1} ; \mathrm{S}\left(\Sigma \mathrm{C}_{4} \mathrm{H}_{8}\right)=73 \%$

$\left(\mathrm{Et}_{2} \mathrm{AlCl}, \mathrm{Al} / \mathrm{Ni}=200 ; 20^{\circ} \mathrm{C} ; 20\right.$ bar $)$

Figure 18. Nickel(II) complexes bearing benzimidazolylpyridine N,N,O-ligands. 
The complex with the butylcarboxamide fragment (23, Figure 19) is more active in comparison with benzimidazole analog (18, Figure 15)-298 $\times 10^{3}$ vs. $57 \times 10^{3} \mathrm{~h}^{-1}$. The selectivity for butenes is $100 \%$ and selectivity for 1-butene $92 \%$ [60].

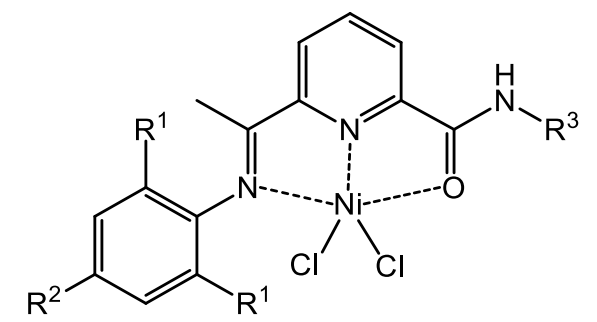

$$
\begin{gathered}
\mathrm{TOF}=(33-298) \times 10^{3} \mathrm{~h}^{-1} ; \\
\mathrm{S}\left(\Sigma \mathrm{C}_{4} \mathrm{H}_{8}\right)=100 \% ; \mathrm{S}\left(1-\mathrm{C}_{4} \mathrm{H}_{8}\right)=70-99 \% \\
\left(\mathrm{Et}_{2} \mathrm{AlCl}, \mathrm{Al} / \mathrm{Ni}=500 ; 20{ }^{\circ} \mathrm{C} ; 10 \mathrm{bar}\right)
\end{gathered}
$$

$\mathrm{R}^{1}=\mathrm{Me}, \mathrm{Et},{ }^{\mathrm{P} r} ; \mathrm{R}^{2}=\mathrm{H} ; \mathrm{R}^{3}={ }^{n} \mathrm{Bu}, \mathrm{n}-$ octyl, n-dodecyl

23

Figure 19. Nickel(II) complexes bearing alkylcarboxamide-iminopyridine ligands.

For the considered complexes 4, 5, 18-23 (Figures 6 and 15-19), there are following regularities regarding the influence of steric and electronic properties of substituents at the $\mathrm{N}$-aryl ring:

-with an increase in the size of the substituents at the ortho positions, the activity decreases due to an increase in steric hindrances near the metal center [53-55,57-60]; the exception are complexes $\mathbf{4 , 5}$ (Figure 6) and 18d (Figure 15) —in their case, the activity increases, since bulky substituents protect the active center from impurities $[40,41,56]$;

-in the case of complexes 18a, 19, 20 and 21 (Figures 15-17), as a result of the introduction Me at the para position, the activity decreases (also due to an increase in steric hindrances for coordination of ethylene to the nickel) [53,57-59]; in the case of complexes 18b-d (Figure 15), the activity increases (due to increased solubility) [54-56];

-as a result of the replacement of Me at the ortho positions by an electron-withdrawing substituent- $\mathrm{Cl}$ or $\mathrm{Br}-$ the activity increases due to an increase in the positive charge on the nickel cation, which facilitates the coordination of ethylene $[37,53,56]$.

Zhang et al. tested $\mathrm{Ni}$ (II) complexes ligated by 2,6-pyridinedicarboxamide derivatives as pre-catalysts for ethylene dimerization (24, Figure 20) [61].<smiles></smiles>

$\mathrm{R}=\mathrm{H}, \mathrm{Me}, \mathrm{Et}, \mathrm{Pr}, \mathrm{Cl}, \mathrm{F}$

$$
\begin{gathered}
\text { TOF }=(39-270) \times 10^{3} \mathrm{~h}^{-1} ; \\
\mathrm{S}\left(\Sigma \mathrm{C}_{4} \mathrm{H}_{8}\right)=97-99 \% ; \mathrm{S}\left(1-\mathrm{C}_{4} \mathrm{H}_{8}\right)=67-82 \% \\
\left(\mathrm{Et}_{2} \mathrm{AlCl}, \mathrm{Al} / \mathrm{Ni}=200 ; 20^{\circ} \mathrm{C} ; 10 \text { bar }\right)
\end{gathered}
$$

24

Figure 20. Nickel(II) complexes bearing 2,6-pyridinedicarboxamide ligands.

Complexes with $\mathrm{Cl}$ and $\mathrm{F}$ at ortho positions of $\mathrm{N}$-aryl ring possess the lowest activity (39-45) $\times 10^{3} \mathrm{~h}^{-1}$, but the highest selectivity for 1-butene-76-82\%. Bulkier substituents in these complexes promote an increase in activity and prevent isomerization. Thus, upon a sequential transition from $\mathrm{R}=\mathrm{H}$ to $\mathrm{R}={ }^{i} \mathrm{Pr}$, the activity increases from $78 \times 10^{3}$ to $270 \times 10^{3} \mathrm{~h}^{-1}$, and the selectivity for 1-butene increases from 67 to $77 \%$ [61].

Mukherjee and co-workers developed nickel(II) complexes bearing pyridine-oxime ligands (25, Figure 21), which can be obtained by a relatively simple route by condensation of commercially available pyridine-2-aldehyde and hydroxylamine $[62,63]$. 


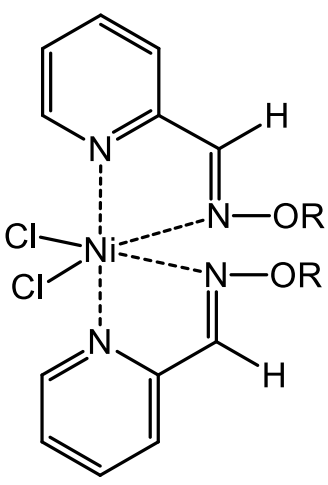

$\mathrm{R}=\mathrm{H}, \mathrm{Me}$

$$
\begin{gathered}
\text { TOF }=(127-136) \times 10^{3} \mathrm{~h}^{-1} ; \\
\mathrm{S}\left(\Sigma \mathrm{C}_{4} \mathrm{H}_{8}\right)=88-90 \% ; \mathrm{S}\left(1-\mathrm{C}_{4} \mathrm{H} 8\right)>99.5 \% \\
\left(\mathrm{Et}_{2} \mathrm{AlCl}, \mathrm{Al} / \mathrm{Ni}=100 ; 45^{\circ} \mathrm{C} ; 26 \text { bar }\right)
\end{gathered}
$$

25

Figure 21. Nickel(II) complexes bearing 2-pyridine-aldoxime ligands.

The complexes remain highly active for a long period of time. Thus, with an increase in the oligomerization time from 45 to $60 \mathrm{~min}$, activity decreases by only $6 \%$. In addition, the complex with $\mathrm{R}=$ Me has high thermal stability: the productivity almost unchanged when the reaction temperature risen from 45 to $95^{\circ} \mathrm{C}$ during the catalytic test [63].

Ojwach and co-workers presented Ni(II) complexes bearing (amino)pyridine ligands (Figure 22) [64].

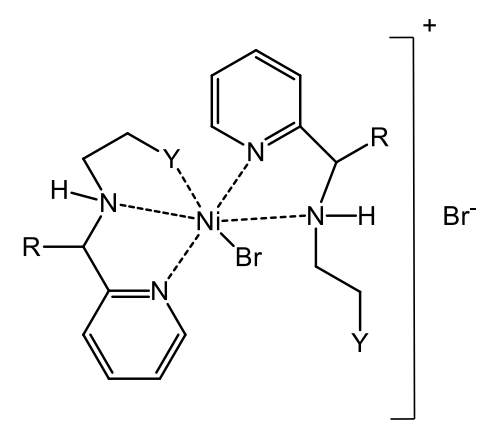

$\mathrm{R}=\mathrm{H}, \mathrm{Me} ; \mathrm{Y}=\mathrm{OMe}, \mathrm{NEt}_{2}$

26

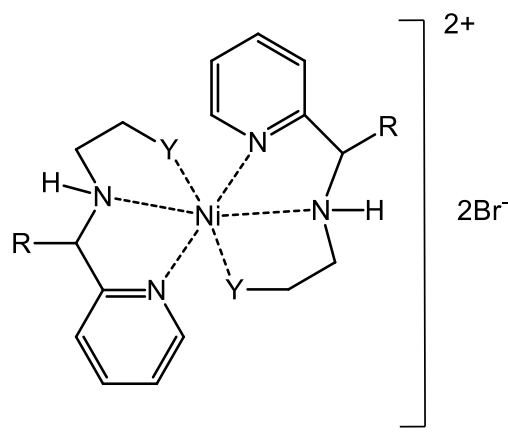

$\mathrm{R}=\mathrm{H}, \mathrm{Y}=\mathrm{OH}$

27

$$
\begin{gathered}
\mathrm{TOF}=(61-80) \times 10^{3} \mathrm{~h}^{-1}, \mathrm{~S}\left(\Sigma \mathrm{C}_{4} \mathrm{H}_{8}\right)=71-77 \%, \mathrm{C}\left(1-\mathrm{C}_{4} \mathrm{H}_{8}\right)=86-94 \% \text { (in } \mathrm{C}_{4} \text {-fraction) } \\
\left(\mathrm{MAO}, \mathrm{Al} / \mathrm{Ni}=1000 ; 30{ }^{\circ} \mathrm{C} ; 10 \mathrm{bar} ; 60 \mathrm{~min}\right)
\end{gathered}
$$

Figure 22. Nickel(II) complexes bearing (amino)pyridine ligands.

The structure of the complexes affects their catalytic properties. Thus, the substitution of OMe-group, bound to the amine $\mathrm{N}$-atom, by the amino group results in activity increase from $61 \times 10^{3}$ to $80 \times 10^{3} \mathrm{~h}^{-1}$. The reason is the stronger coordination of oxygen to the nickel, which leads to its competition with the ethylene molecule for a vacant coordination center [64].

\subsubsection{Nickel Complexes Bearing Quinoline Ligands}

Sun and co-workers proposed an analog of complexes 18, in which quinoline is used instead of pyridine (28, Figure 23a) [65,66]. 
<smiles></smiles>

28<smiles></smiles>

$\mathrm{R}^{1}=\mathrm{H}, \mathrm{R}^{2}=\mathrm{Me}$

$$
\begin{gathered}
\text { TOF }=273 \times 10^{3} \mathrm{~h}^{-1} ; \\
\mathrm{S}\left(\Sigma \mathrm{C}_{4} \mathrm{H}_{8}\right)=83 \% ; \mathrm{S}\left(1-\mathrm{C}_{4} \mathrm{H}_{8}\right)=38 \%
\end{gathered}
$$$$
29
$$

$\left(\mathrm{Et}_{2} \mathrm{AlCl}, \mathrm{Al} / \mathrm{Ni}=200 ; 20^{\circ} \mathrm{C} ; 10\right.$ bar $)$

(a)

(b)

Figure 23. Nickel(II) complexes bearing benzimidazole-quinoline ligands: benzimidazole-quinoline-amine (a) and benzimidazole-N-benzylidenequinoline-amine (b).

As a result of the replacement of Me at the $\mathrm{N}$-atom of the amino group by benzylidene (29, Figure 23b), the activity decreases by 2.5 times [66].

$\mathrm{Ni}^{\mathrm{II}}$ complexes bearing $\mathrm{N}, \mathrm{N}, \mathrm{O}-$ ligands (30, Figure 24) were presented in [67].<smiles></smiles>

$\mathrm{X}=\mathrm{Cl}, \mathrm{Br} ; \mathrm{R}^{1}=\mathrm{Me}, \mathrm{Et},{ }^{i} \mathrm{Pr} ; \mathrm{R}^{2}=\mathrm{H}, \mathrm{Cl}$

$$
\begin{gathered}
\mathrm{TOF}=(21-153) \times 10^{3} \mathrm{~h}^{-1} ; \\
\mathrm{S}\left(\Sigma \mathrm{C}_{4} \mathrm{H}_{8}\right)=91-99 \% ; \\
\mathrm{C}\left(1-\mathrm{C}_{4} \mathrm{H}_{8}\right)=51-93 \% \text { (in } \mathrm{C}_{4} \text {-fraction) } \\
\left(\mathrm{Et}_{2} \mathrm{AlCl}, \mathrm{Al} / \mathrm{Ni}=200 ; 60^{\circ} \mathrm{C} ; 10 \text { bar }\right)
\end{gathered}
$$

\section{0}

Figure 24. Nickel(II) complexes bearing 2-benzoimidazol-8-ethoxyquinoline ligands.

Complexes 30 have greater thermal stability compared to typical imine systems: when the oligomerization temperature is elevated from 20 to $60^{\circ} \mathrm{C}$, the activity increases from $5 \times 10^{3}$ to $153 \times 10^{3} \mathrm{~h}^{-1}$. With a further elevation of temperature to $80^{\circ} \mathrm{C}$ activity decreases to $2 \times 10^{3} \mathrm{~h}^{-1}$. In addition, for these systems, the activity of chloride complexes is greater than bromide counterparts. This is explained by similar solubility of chloride and bromide complexes and the determining influence on the activity of the net charge of the complex (activity increases with the increased net charge) [67].

Pyridine-quinoline-imine ligands were synthesized, which are the analogs of arylimino-phenanthroline $\mathrm{N}, \mathrm{N}, \mathrm{N}$-ligands (13, Figure 13a), also possessing a conjugated electronic system and similar coordination environment [34]. Based on these ligands, complexes 32 were obtained (Figure 25b).

These complexes are less active compared to the arylimino-phenanthroline analogs 31 (13). Electron-donors as the $\mathrm{R}^{2}$-substituent have a negative effect on catalytic properties: the most active-(147-169) $\times 10^{3} \mathrm{~h}^{-1}$-are complexes containing a hydrogen atom as $\mathrm{R}^{2}$. With an increase in the electron-donor properties of $\mathrm{R}^{2}$ (in transition from $\mathrm{H}$ to $\mathrm{Me}$ and $\mathrm{Ph}$ ), the activity decreases. The introduction of Me at $R^{1}$ and $R^{3}$ positions results in activity reduction by 2-6 times. This is due to the blocking of the active sites of the catalyst by bulky substituents. With sequential changing of $\mathrm{R}^{1}$ 
substituent from $\mathrm{Me}$ to ${ }^{i} \mathrm{Pr},{ }^{t} \mathrm{Bu}$, and $\mathrm{Cy}$, the activity increases, probably due to the protection of the active sites from decomposition by bulky substituents [34].

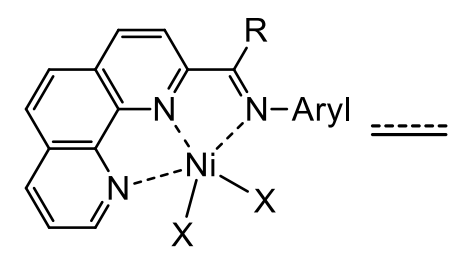

31

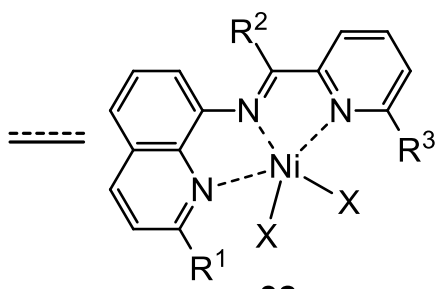

32

$\mathrm{R}^{1}=\mathrm{H}, \mathrm{Me},{ }^{i \mathrm{Pr}},{ }^{t} \mathrm{Bu}, \mathrm{Cy} ; \mathrm{R}^{2}=\mathrm{H}, \mathrm{Me}, \mathrm{Ph} ; \mathrm{R}^{3}=$

$\mathrm{H}, \mathrm{Me} ; \mathrm{X}=\mathrm{Cl}, \mathrm{Br}$

(a)

$$
\begin{gathered}
\mathrm{TOF}=(131-220) \times 10^{3} \mathrm{~h}^{-1} ; \mathrm{S}\left(\Sigma \mathrm{C}_{4} \mathrm{H}_{8}\right)=98-99 \% \\
\left(\mathrm{Et}_{2} \mathrm{AlCl}, \mathrm{Al} / \mathrm{Ni}=300 ; 30^{\circ} \mathrm{C} ; 10 \text { bar }\right)
\end{gathered}
$$

(b)

$$
\begin{gathered}
\text { TOF }=(18-169) \times 10^{3} \mathrm{~h}^{-1} ; \mathrm{S}\left(\Sigma \mathrm{C}_{4} \mathrm{H}_{8}\right)= \\
93-99 \% ; \mathrm{S}\left(1-\mathrm{C}_{4} \mathrm{H}_{8}\right)=82-95 \% \\
\left(\mathrm{Et}_{2} \mathrm{AlCl}, \mathrm{Al} / \mathrm{Ni}=500 ; 20{ }^{\circ} \mathrm{C} ; 30 \text { bar }\right)
\end{gathered}
$$

Figure 25. Nickel(II) complexes bearing arylimino-phenanthroline (a) and pyridine-quinoline-imine ligands (b).

Analogs of the above mentioned complexes 32 with a phenolate fragment instead of pyridine (33, Figure 26) are less active [68]. This is probably due to greater interaction of the metal center with oxygen compared to nitrogen.

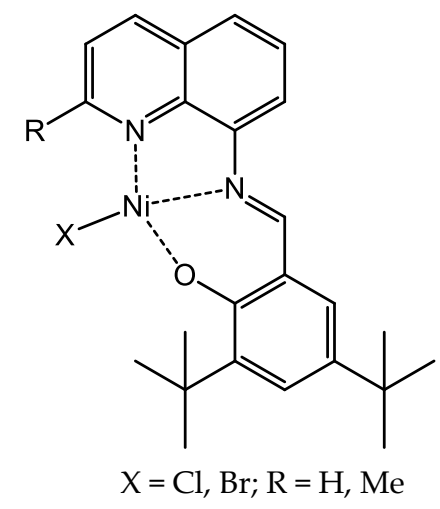

$$
\begin{gathered}
\text { TOF }=(4-11) \times 10^{3} \mathrm{~h}^{-1} ; \\
\mathrm{S}\left(\Sigma \mathrm{C}_{4} \mathrm{H}_{8}\right)=93-96 \% ; \\
\mathrm{C}\left(1-\mathrm{C}_{4} \mathrm{H}_{8}\right)=11-31 \% \text { (in } \mathrm{C}_{4} \text {-fraction) } \\
\left(\mathrm{Et}_{2} \mathrm{AlCl}, \mathrm{Al} / \mathrm{Ni}=200 ; 20^{\circ} \mathrm{C} ; 1\right. \text { bar) }
\end{gathered}
$$$$
33
$$

Figure 26. Nickel(II) complexes bearing phenolate-quinoline-imine ligands.

Me substituent at the quinoline fragment stabilizes the active sites from the impact of impurities and thereby causes an increase in activity from $4 \times 10^{3}$ to $(10-11) \times 10^{3} \mathrm{~h}^{-1}$. Another reason for the increased activity with the Me introduction is an increase in solubility of complexes [68].

\subsubsection{Nickel Complexes Bearing Pyrrole- and Imidazole-Imine Ligands}

Casagrande and co-workers developed various pre-catalysts for ethylene dimerization based on nickel complexes bearing ligands containing an imino group bonded to pyrrole [69], furan [45] or phenyl [49]. Thus, in [69] nickel complexes bearing pyrrole-imine ligands with pendant $\mathrm{O}-$ and S-donor groups were studied (34a-f, Figure 27). These groups are coordinated to nickel and thereby stabilize the active site. 
<smiles>[R]c1ccc2n1[N+]1(Cl)C=CN2CCCC1</smiles>

34<smiles></smiles><smiles></smiles>

34c: $R=H, Z=$<smiles>[3H]CCOc1ccccc1</smiles>

34f: $R=H, Z=$<smiles>[Z]c1ccccc1OC</smiles>
$\mathrm{TOF}=(6-71) \times 10^{3} \mathrm{~h}^{-1} ; \mathrm{S}\left(1-\mathrm{C}_{4} \mathrm{H}_{8}\right)=72-94 \%\left(\mathrm{MAO}, \mathrm{Al} / \mathrm{Ni}=250 ; 30^{\circ} \mathrm{C} ; 20 \mathrm{bar}\right)$

Figure 27. Nickel(II) complexes with pyrrole-imine ligands.

The most active in oligomerization $\left(71 \times 10^{3} \mathrm{~h}^{-1}\right)$ is the complex 34e with a rigid ligand skeleton and a soft donor group S-Ph [69].

Olivier-Bourbigou et al. synthesized an analog of the 34 complexes (35, Figure 28) [70].<smiles>COc1ccccc1N1C=C2N(C)C=CN2[N+](Cl)(Cl)C1(Cl)Cl</smiles>

$$
\begin{gathered}
\mathrm{TOF}=37 \times 10^{3} \mathrm{~h}^{-1} \\
\mathrm{~S}\left(\Sigma \mathrm{C}_{4} \mathrm{H}_{8}\right)=88 \% \\
\mathrm{C}\left(1-\mathrm{C}_{4} \mathrm{H}_{8}\right)=30 \% \text { (in } \mathrm{C}_{4} \text {-fraction) } \\
\left(\mathrm{MAO}, \mathrm{Al} / \mathrm{Ni}=500 ; 45^{\circ} \mathrm{C} ; 30 \text { bar; } 50 \mathrm{~min}\right)
\end{gathered}
$$

35

Figure 28. Nickel(II) complex bearing imino-imidazole ligand.

The complex 35 is more active compared to $34-37 \times 10^{3}$ vs. $6 \times 10^{3} \mathrm{~h}^{-1}$, with a longer oligomerization cycle-50 min vs. 20 min [70].

\subsection{5. $\beta$-Ketoimine Nickel(II) Complexes}

Wang and co-workers developed highly effective pre-catalysts for ethylene dimerization-nickel(II) complexes with $\beta$-ketoimine ligands (36a-o, Figure 29) [71].<smiles></smiles>

36a-k<smiles>Pc1cccc(-c2ccccc2)c1</smiles>

361

\begin{tabular}{|c|c|c|c|}
\hline $\mathbf{L}$ & $\mathrm{R}^{1}$ & $\mathrm{R}^{2}$ & $x$ \\
\hline $\mathbf{a}$ & $\mathrm{Ph}$ & $\mathrm{Ph}$ & S-Me \\
\hline b & $\mathrm{Ph}$ & $\mathrm{Ph}$ & S-iPr \\
\hline c & $\mathrm{Ph}$ & $\mathrm{Ph}$ & $\mathrm{S}-{ }^{n} \mathrm{Pr}$ \\
\hline d & $\mathrm{Ph}$ & $\mathrm{Ph}$ & $\mathrm{S}-{ }^{-} \mathrm{Bu}$ \\
\hline e & $\mathrm{Ph}$ & $\mathrm{Ph}$ & $\mathrm{S}-\mathrm{Ph}$ \\
\hline $\mathrm{f}$ & $\mathrm{Ph}$ & $\mathrm{Ph}$ & S-Cy \\
\hline $\mathrm{g}$ & $\mathrm{Ph}$ & $\mathrm{CH}_{3}$ & S- $-\mathrm{Pr}$ \\
\hline h & $\mathrm{CH}_{3}$ & $\mathrm{CF}_{3}$ & S- $-i \operatorname{Pr}$ \\
\hline $\mathbf{i}$ & $\mathrm{Ph}$ & $\mathrm{Ph}$ & $\mathrm{NMe}_{2}$ \\
\hline $\mathbf{j}$ & $\mathrm{Ph}$ & $\mathrm{Ph}$ & $\mathrm{PPh}_{2}$ \\
\hline $\mathbf{k}$ & $\mathrm{Ph}$ & $\mathrm{Ph}$ & $\mathrm{O}-\mathrm{Ph}$ \\
\hline
\end{tabular}<smiles>[R]c1cccc([R])c1Sc1ccccc1N1C(C)C=C(c2ccccc2)O[N+]1([PH])[PH2+]</smiles>

$36 \mathrm{~m} \mathrm{R}=\mathrm{Me}$ 36n $\mathrm{R}=\mathrm{H}$
$\mathrm{TOF}=(130-3339) \times 10^{3} \mathrm{~h}^{-1} ; \mathrm{S}\left(\Sigma \mathrm{C}_{4} \mathrm{H}_{8}\right)=90->99 \% ; \mathrm{S}\left(1-\mathrm{C}_{4} \mathrm{H}_{8}\right)=10-88 \%$

(MAO, $\mathrm{Al} / \mathrm{Ni}=1000 ; 0{ }^{\circ} \mathrm{C} ; 10$ bar; solvent $-\mathrm{CH}_{2} \mathrm{Cl}_{2} ; 5 \mathrm{~min}$ )

Figure 29. $\beta$-Ketoimine nickel(II) complexes. 
The highest activity (TOF $=3339 \times 10^{3} \mathrm{~h}^{-1}$ ) is observed for the complex 361 with a phenoxy substituent and $\mathrm{PPh}_{3}$, which is coordinated to nickel. However, the selectivity of this complex for 1-butene is low, 13\% [71].

With an increase in the size of the substituent at the sulfur atom, the oligomerization activity increases. Thus, replacement of $\mathrm{Me}(36 \mathrm{a})$ by ${ }^{t} \mathrm{Bu}(36 \mathrm{~d})$ leads to increase both in activity (from $657 \times 10^{3}$ to $1121 \times 10^{3} \mathrm{~h}^{-1}$ ) and selectivity for butenes (from $96 \%$ to $>99 \%$ ), but the selectivity for 1-butene almost unchanged ( $81 \%$ vs. $82 \%$, respectively). The introduction of the electron-withdrawing $\mathrm{CF}_{3}$ group (36h) as a substituent at the C-imine atom, results in the reduction of activity to $125 \times 10^{3} \mathrm{~h}^{-1}$.

As a result of the replacement of sulfur atom (36a) by the nitrogen one (36i) in substituent $X$ activity decreases to $325 \times 10^{3} \mathrm{~h}^{-1}$, selectivity for butenes rises to $>99 \%$ and selectivity for 1-butene-to $87 \%$.

As a result of the replacement of the $-\mathrm{CH}_{2}-\mathrm{CH}_{2}-$ bridge between the nitrogen and sulfur atoms by a phenylene one and, accordingly, the formation of a rigid skeleton, as well as due to the coordination of $\mathrm{PPh}_{3}$ to nitrogen, the activity of the resulting complex $36 \mathrm{~m}$ with the $-\mathrm{S}-(2,6-\mathrm{diMe}) \mathrm{C}_{6} \mathrm{H}_{3}$ moiety increases to $3014 \times 10^{3} \mathrm{~h}^{-1}$, but the selectivity for 1-butene decreases to $10 \%$. Upon the transition from (2,6-diMe) $\mathrm{C}_{6} \mathrm{H}_{3}(\mathbf{3 6 m})$ to $\mathrm{Ph}(\mathbf{3 6 n})$ at the S-atom, the activity decreases to $1671 \times 10^{3} \mathrm{~h}^{-1}$ [71].

\section{Nickel Complexes Bearing Pyrazolyl Ligands}

Due to the $\sigma$-donor ability of the nitrogen atom and the ability to fine-tune its electronic properties by selecting substituents, pyrazole is increasingly used to obtain transition metal complexes that are catalytically active in C-C bonding processes [72-74]. For example, Casagrande and co-workers developed various nickel complexes bearing pyrazolyl-based ligands. In [75] the nickel(II) complexes with bidentate phenoxy-pyrazolyl ligands were tested in the ethylene oligomerization process (37, Figure 30).

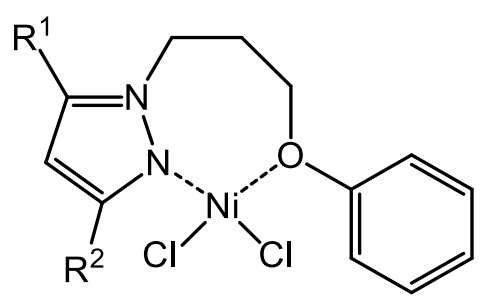

$$
\begin{gathered}
\text { TOF }=(18-46) \times 10^{3} \mathrm{~h}^{-1} \\
\mathrm{~S}\left(\Sigma \mathrm{C}_{4} \mathrm{H}_{8}\right)=91-95 \% ; \mathrm{S}\left(1-\mathrm{C}_{4} \mathrm{H}_{8}\right)=69-84 \% \\
\left(\mathrm{MAO}, \mathrm{Al} / \mathrm{Ni}=250 ; 20 \text { bar; } 30^{\circ} \mathrm{C}\right)
\end{gathered}
$$

$\mathrm{R}^{1}=\mathrm{H}, \mathrm{Me} ; \mathrm{R}^{2}=\mathrm{H}, \mathrm{Me},{ }^{t} \mathrm{Bu}, \mathrm{Ph}$

37

Figure 30. Nickel(II) complexes with phenyl ether-pyrazolyl ligands.

The complex, which has no substituents at the pyrazole ring, is the least active (TOF $=18 \times 10^{3} \mathrm{~h}^{-1}$ ) due to the least donating ability of the pyrazole fragment. The highest activity $\left(46 \times 10^{3} \mathrm{~h}^{-1}\right)$ is observed for the complex with Me at the positions 3 and 5 of pyrazole. Bulkier substituents $\left(\mathrm{Ph},{ }^{t} \mathrm{Bu}\right)$ cause less activity due to the steric hindrances for the ethylene insertion. Active sites of oligomerization have a short lifetime: in the period from 10 to $20 \mathrm{~min}$, the activity decreases by 1.7 times, while the selectivity for butenes almost unchanged-92\% vs. 91\%, respectively [75].

As the dimerization pre-catalysts, the $\mathrm{Ni}^{\mathrm{II}}$ bis-chelate complexes bearing bidentate $\mathrm{N}$,Se-ligands have also been proposed (38, Figure 31) [76].

With an increase in the size of the chelate ring from five to six, the activity decreases from $23 \times 10^{3}$ to $10 \times 10^{3} \mathrm{~h}^{-1}$, it indicates the formation of a more rigid and stable structure of the active site in the case of the five-membered chelate ring. As a result of the introduction of electron-withdrawing $(\mathrm{Cl})$ and donor $(\mathrm{OMe})$ substituent at the para position of the benzene ring, the activity decreases to $19 \times 10^{3}$ and $15 \times 10^{3} \mathrm{~h}^{-1}$, respectively. At the same time, selectivity for 1-butene remains almost unchanged $(92-94 \%)$ [76]. 


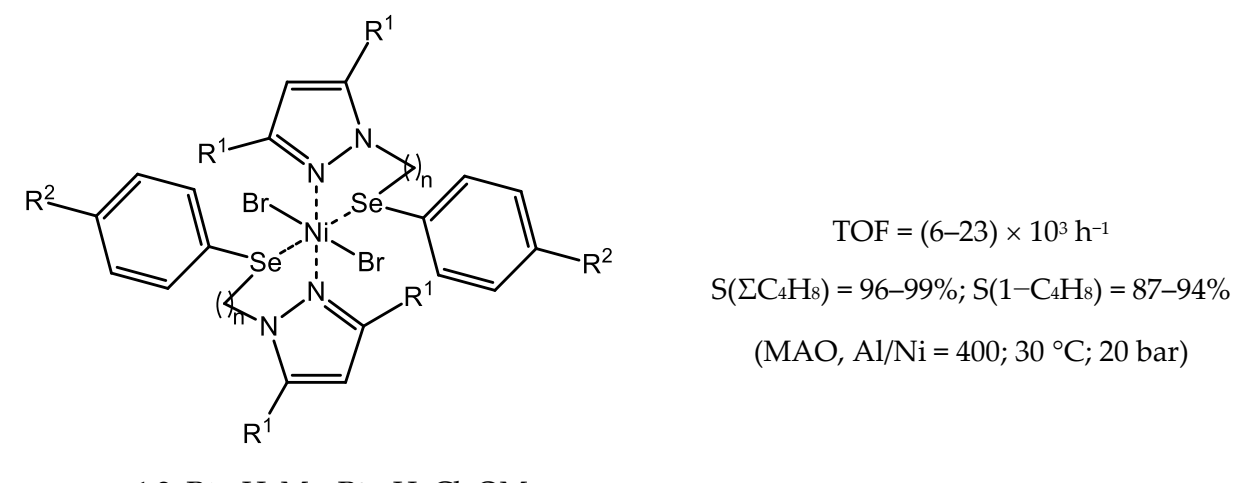

$\mathrm{n}=1,2 ; \mathrm{R}^{1}=\mathrm{H}, \mathrm{Me} ; \mathrm{R}^{2}=\mathrm{H}, \mathrm{Cl}, \mathrm{OMe}$

38

Figure 31. Nickel(II) complexes with arylselenyl-pyrazolyl ligands.

The same research group developed nickel(II) complexes with nitrogen-, oxygen-, or sulfur-bridged bis(pyrazolyl) ligands. For example, $\mathrm{Ni}^{\mathrm{II}}$ complexes with $\mathrm{N}, \mathrm{Z}, \mathrm{N}-$ ligands $(\mathrm{Z}=\mathrm{N}, \mathrm{O}$, or $\mathrm{S})$, that form two six-membered chelating rings, were studied (39, Figure 32) as pre-catalysts for ethylene oligomerization [77].<smiles></smiles>

$\mathrm{Z}=\mathrm{NH}, \mathrm{O}, \mathrm{S} ; \mathrm{R}^{1}=\mathrm{H}, \mathrm{Me} ; \mathrm{R}^{2}=\mathrm{Me},{ }^{\mathrm{t} B u}$,

$\mathrm{Ph}$

39

\author{
$\mathrm{TOF}=(7-57) \times 10^{3} \mathrm{~h}^{-1}$ \\ $\mathrm{S}\left(\Sigma \mathrm{C}_{4} \mathrm{H}_{8}\right)=99 \%$; \\ $\mathrm{C}\left(1-\mathrm{C}_{4} \mathrm{H}_{8}\right)=72-88 \%$ (in $\mathrm{C}_{4}$-fraction) \\ (MAO, $\mathrm{Al} / \mathrm{Ni}=250 ; 20 \mathrm{bar} ; 30^{\circ} \mathrm{C}$ )
}

Figure 32. Nickel(II) complexes with bridged bis(pyrazolyl) ligands.

The complex with a sulfur bridge possesses the highest activity $\left(57 \times 10^{3} \mathrm{~h}^{-1}\right)$ and the lowest selectivity for 1-butene (72\%). As a result of $\mathrm{PPh}_{3}$ addition (1 equivalent), the activity increases from $7 \times 10^{3}$ to $113 \times 10^{3} \mathrm{~h}^{-1}$, selectivity for butenes remains unchanged $(99 \%)$, and selectivity for 1-butene decreases from $88 \%$ to $16 \%$. The increased activity may be due to a stabilization of active sites by $\mathrm{PPh}_{3}$, and the decrease in selectivity for 1-butene is due to blocking of ethylene coordination and the preferred 1-butene isomerization instead of $\beta$-elimination [77,78].

In $[78,79]$ the analogs of complexes 39 with two five-membered chelate rings were presented $(\mathbf{4 0}$, Figure 33).

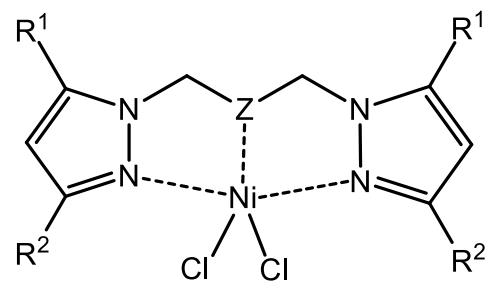

$\mathrm{Z}=\mathrm{N}-\mathrm{Bz}, \mathrm{S} ; \mathrm{R}^{1}=\mathrm{H}, \mathrm{Me} ; \mathrm{R}^{2}=\mathrm{Me}, \mathrm{Ph}$

$$
\mathrm{TOF}=(4-105) \times 10^{3} \mathrm{~h}^{-1} ;
$$$$
\mathrm{S}\left(\Sigma \mathrm{C}_{4} \mathrm{H}_{8}\right)=95-100 \% \text {; }
$$

$\mathrm{C}\left(1-\mathrm{C}_{4} \mathrm{H}_{8}\right)=72-94 \%$ (in $\mathrm{C}_{4}$-fraction)

(MAO, $\mathrm{Al} / \mathrm{Ni}=250 ; 30^{\circ} \mathrm{C} ; 20$ bar)

40

Figure 33. Bis(pyrazolyl) nickel(II) complexes with two five-membered chelate rings. 
The most active is the complex with a sulfur-bridge and Me at positions 3 and 5 of pyrazole rings: the activity is $105 \times 10^{3} \mathrm{~h}^{-1}$, the selectivity for butenes is $98 \%$, including $72 \%$-for 1-butene. Changing of Me by a bulkier Ph leads to a decrease in activity to $19 \times 10^{3} \mathrm{~h}^{-1}$. At the same time, substituents at the pyrazole ring and a bridging donor atom do not significantly affect selectivity for butenes [78,79].

Thus, complex 40 with a five-membered chelate ring (Figure 33) has ca. 2 times higher activity in ethylene dimerization compared to analog (39) with a six-membered ring (Figure 32) due to a greater stability of active sites [77-79].

The analogs of complex 40 immobilized on the surface of silica gel were synthesized by Tuskaev et al. [80]. As a result of interaction between silica gel grafted aminopropyl groups and 1-hydroxymethylpyrazole, surface bis(pyrazolyl)amine ligands were formed, to which nickel dibromide was subsequently coordinated (41, Figure 34$)$.

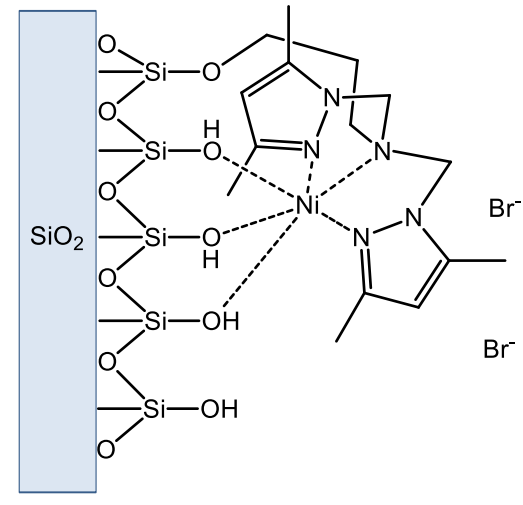

41

$\mathrm{TOF}=12 \times 10^{3} \mathrm{~h}^{-1} ;$

$$
\mathrm{S}\left(\Sigma \mathrm{C}_{4} \mathrm{H}_{8}\right)=92 \% ; \mathrm{S}\left(1-\mathrm{C}_{4} \mathrm{H}_{8}\right)=69 \%
$$

$\left(\mathrm{Et}_{2} \mathrm{AlCl}, \mathrm{Al} / \mathrm{Ni}=150 ; 3 \mathrm{bar} ; 30^{\circ} \mathrm{C}\right)$

(a)

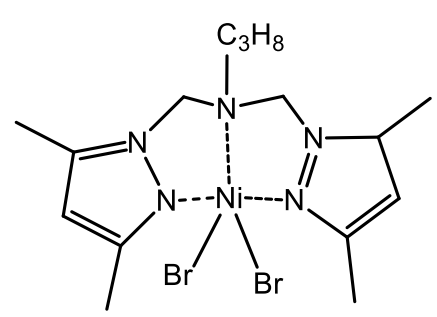

42

$\mathrm{TOF}=9 \times 10^{3} \mathrm{~h}^{-1} ;$

$\mathrm{S}\left(\Sigma \mathrm{C}_{4} \mathrm{H}_{8}\right)=91 \% ; \mathrm{S}\left(1-\mathrm{C}_{4} \mathrm{H}_{8}\right)=34 \%$

(b)

Figure 34. Nickel(II) complexes bearing bridged bis(pyrazolyl) ligands:silica-immobilized complex (a) and single complex (b).

The immobilized catalytic system possesses higher oligomerization activity in comparison with the homogeneous system (42, Figure 34b). At the same time, the selectivity for 1-butene increases from 30 to $60-70 \%$. The differences in the catalytic properties are due to the different coordination environment of the metal center. In the case of a homogeneous complex, nickel has an orthorhombic environment created by bromine atoms and three nitrogen atoms of the ligand. In the case of the immobilized complex, the coordination of the nickel atom is close to octahedral [80].

The substitution of one of the pyrazole rings by $\mathrm{O}$ - or S-donor group leads to an increase in activity. Thus, complex 43 (Figure 35a) with a phenoxy group is more active as compared to bis(pyrazolyl) complex $39\left(\mathrm{Z}=\mathrm{O}, \mathrm{R}^{1}=\mathrm{R}^{2}=\mathrm{Me}\right.$; Figure 32$)-36 \times 10^{3}$ vs. $7 \times 10^{3}$ [77]. The introduction of ${ }^{i} \mathrm{Pr}$ at the ortho position of Z-aryl ring leads to a decrease in activity (44, Figure 35b) [81].

Complex 45, which has sulfur as the heteroatom (Figure 35c), is less active than the oxygen-containing counterpart 43 (Figure 35a) but is more selective for 1-butene [81].

Based on the analysis of the results obtained by Casagrande and co-workers [69,79], it was concluded that the soft donor atom in the tridentate pyrazolyl ligand stabilizes the active sites of ethylene dimerization. Therefore, complexes 46 with selenium-containing ligands were synthesized (Figure 35d) [82]. The introduction of Me at the positions 3 and 5 of the pyrazole ring causes an increase in activity from $4 \times 10^{3}$ to $24 \times 10^{3} \mathrm{~h}^{-1}$. This is due to an increase in the electron-donor ability of pyrazole fragment, which leads to greater stabilization of the active sites. The introduction of OMe or $\mathrm{Cl}$ at the para position of the Se-aryl ring does not affect the activity and selectivity for butenes. 
This phenomenon is due to a weak interaction of Ni with Se. Hemilability of the aryselenyl moiety facilitates the coordination of ethylene to the metal center [82].

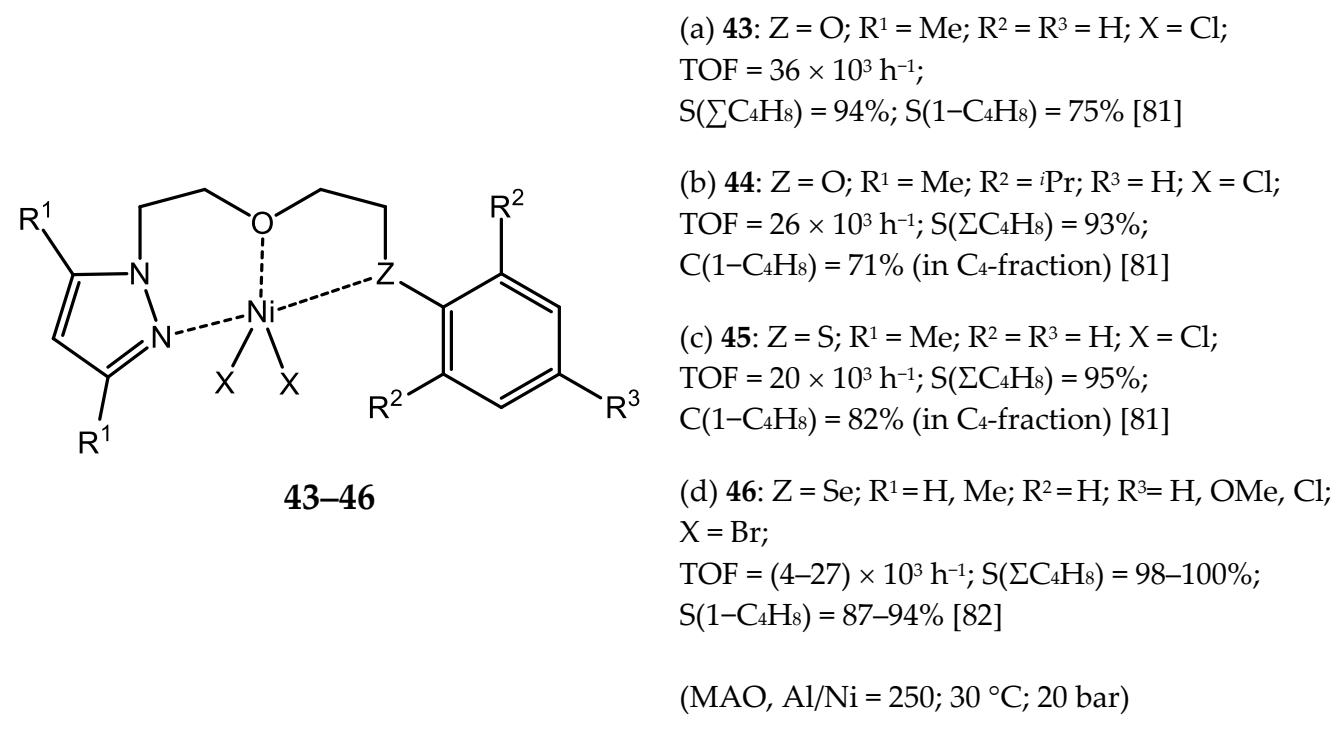

Figure 35. Nickel(II) complexes bearing ether-pyrazolyl ligands with pendant donor groups.

Ojwach et al. developed an analog of bis(pyrazolyl) complexes 40 (Figure 33) $-\mathrm{Ni}^{\mathrm{II}}$ complex bearing bis(pyrazolyl)pyridine ligand (47, Figure 36) [83].

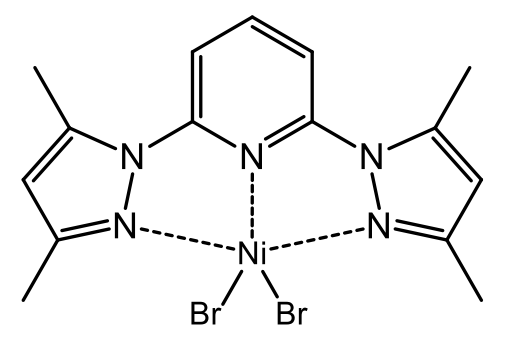

47

\author{
$\mathrm{TOF}=11 \times 10^{3} \mathrm{~h}^{-1} ;$ \\ $\mathrm{S}\left(\Sigma \mathrm{C}_{4} \mathrm{H}_{8}\right)=86 \%$; \\ $\mathrm{C}\left(1-\mathrm{C}_{4} \mathrm{H}_{8}\right)=87 \%$ (in $\mathrm{C}_{4}$-fraction) \\ (MAO, $\mathrm{Al} / \mathrm{Ni}=1000 ; 30^{\circ} \mathrm{C} ; 10$ bar; $60 \mathrm{~min}$ )
}

Figure 36. Nickel(II) complex bearing bis(pyrazolyl)pyridine ligand.

Complexes 48 with a bidentate ligand and one five-membered chelate ring (Figure 37) are more active than complex 47 , which may be due to the higher electrophilicity of the bidentate ligand caused by the presence of bromide at the pyridine ring. Also, in these complexes, the Ni center is less shielded by a ligand [83].<smiles></smiles>

48

$$
\begin{gathered}
\mathrm{TOF}=(29-36) \times 10^{3} \mathrm{~h}^{-1} ; \\
\mathrm{S}\left(\Sigma \mathrm{C}_{4} \mathrm{H}_{8}\right)=86-87 \% ; \\
\mathrm{S}\left(1-\mathrm{C}_{4} \mathrm{H}_{8}\right)=86-87 \% \text { (in } \mathrm{C}_{4} \text {-fraction) } \\
\left(\mathrm{MAO}, \mathrm{Al} / \mathrm{Me}=1000 ; 30{ }^{\circ} \mathrm{C} ; 10\right. \text { bar) }
\end{gathered}
$$

Figure 37. Nickel(II) complexes bearing pyrazolyl-pyridine ligand. 
The substitution of bromide at the position 6 of the pyridine ring by phosphinoyl is followed by the appearance of additional coordination of oxygen to nickel (49, Figure 38), which results in the activity reduction, and in the increased butenes and 1-butene selectivities [84].

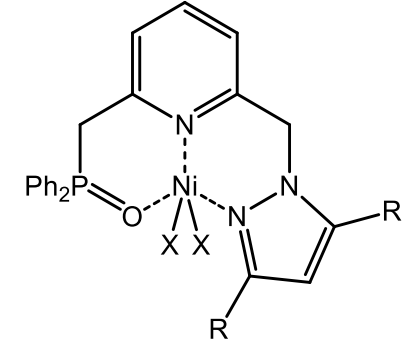

$\mathrm{X}=\mathrm{Cl}, \mathrm{Br} ; \mathrm{R}=\mathrm{Me}, \mathrm{Ph}$

\author{
$\mathrm{TOF}=13 \times 10^{3} \mathrm{~h}^{-1}$; \\ $\mathrm{S}\left(\Sigma \mathrm{C}_{4} \mathrm{H}_{8}\right)=94 \% ; \mathrm{S}\left(1-\mathrm{C}_{4} \mathrm{H}_{8}\right)=65 \%$ \\ $\left(\mathrm{EtAlCl}_{2}, \mathrm{Al} / \mathrm{Ni}=250 ; 30^{\circ} \mathrm{C} ; 10\right.$ bar)
}

49

Figure 38. Nickel(II) complexes bearing (pyrazolyl)-(phosphinoyl)pyridine ligands.

With an increase in the size of a substituent at pyrazole ring-upon transition from $\mathrm{Me}$ to $\mathrm{Ph}$ (Figure 38) - the activity decreases from $13 \times 10^{3}$ to $10 \times 10^{3} \mathrm{~h}^{-1}$ [84]. A similar pattern was observed in [79]; it may be due to the fact that a bulkier ligand prevents the coordination of ethylene to the metal center.

Casagrande and co-workers developed highly-selective for 1-butene catalytic systems based on pyrazolyl-phosphinoyl nickel(II) complexes (50, Figure 39) [85].

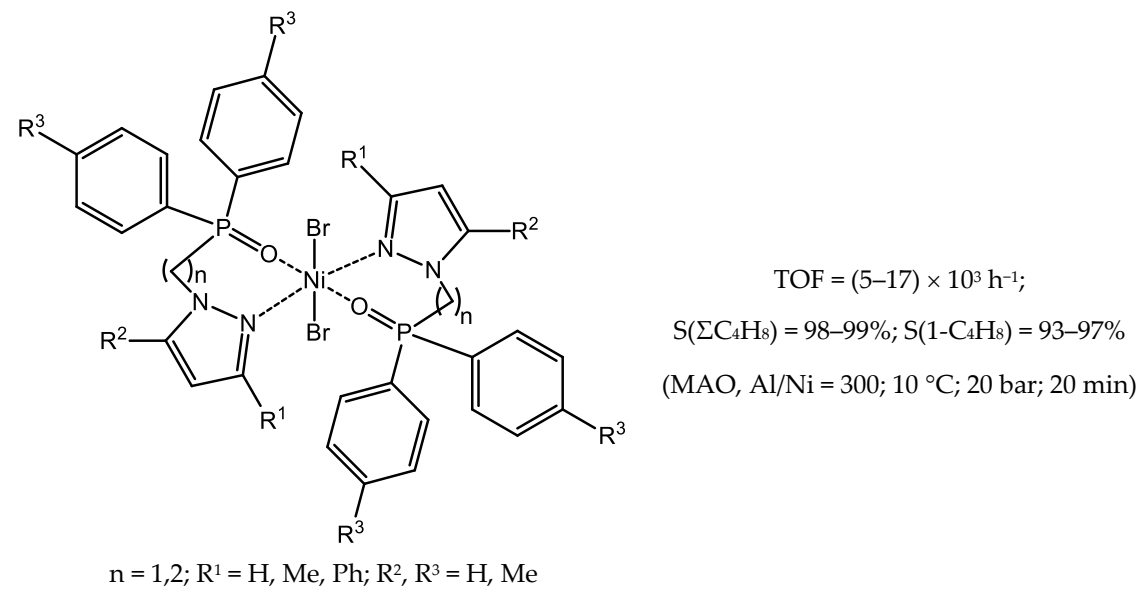

50

Figure 39. Nickel(II) complexes bearing pyrazolyl-phosphinoyl ligands.

In [86] bis(pyrazolyl)methane nickel(II) complex was studied as pre-catalysts for ethylene dimerization (51, Figure 40).<smiles></smiles>

51

$$
\begin{gathered}
\mathrm{TOF}=10 \times 10^{3} \mathrm{~h}^{-1} ; \\
\mathrm{S}\left(\Sigma \mathrm{C}_{4} \mathrm{H}_{8}\right)=97 \% ; \mathrm{S}\left(1-\mathrm{C}_{4} \mathrm{H}_{8}\right)=93 \% \\
\left(\mathrm{Et}_{3} \mathrm{Al}_{2} \mathrm{Cl}_{3}, \mathrm{Al} / \mathrm{Ni}=150 ; 30^{\circ} \mathrm{C} ; 3 \text { bar }\right)
\end{gathered}
$$

Figure 40. Nickel(II) complex bearing bis(pyrazolyl)methane ligand. 
Jiang and co-workers synthesized nickel(II) complexes with silicon- and phosphorus-bridged bis(pyrazolyl) ligands (52 and 53, Figure 41) [87].<smiles></smiles>

52

$$
\mathrm{TOF}=12 \times 10^{3} \mathrm{~h}^{-1} ;
$$

$\mathrm{S}\left(\Sigma \mathrm{C}_{4} \mathrm{H}_{8}\right)=93 \% ; \mathrm{S}\left(1-\mathrm{C}_{4} \mathrm{H}_{8}\right)=84 \%$

(a)<smiles></smiles>

53

$$
\mathrm{S}\left(\Sigma \mathrm{C}_{4} \mathrm{H}_{8}\right)=90 \% ; \mathrm{S}\left(1-\mathrm{C}_{4} \mathrm{H}_{8}\right)=84 \%
$$

(b)

(MAO, $\mathrm{Al} / \mathrm{Ni}=800 ; 30{ }^{\circ} \mathrm{C} ; 8$ bar)

Figure 41. Nickel(II) complexes with Si- (a) and P-bridged (b) bis(pyrazolyl) ligands.

Complex 52 with a dimethylsilane ligand is more active than complex 53 with a phenylphosphine ligand at close selectivities for butenes and 1-butene. Higher activity of complex $\mathbf{5 2}$ is due to the fact that two Me at the silicon atom, being stronger electron donors in comparison with Ph, stabilize catalytically active cationic particles or facilitate their formation. Another reason for the higher activity of $\mathbf{5 2}$ compared to $\mathbf{5 3}$ is the larger atomic radius of silicon and its lower electronegativity compared to phosphorus, as a result of which the "bite angle" of the dimethylsilane ligand promotes the formation of an optimal electronic and coordination state of the Ni-center [87].

Tuskaev et al. developed $\mathrm{Ni}^{\mathrm{II}}$ complexes bearing heteroscorpionate ligands (54, Figure 42) [88].

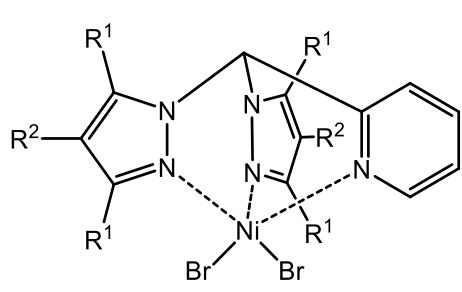

$\mathrm{R}^{1}=\mathrm{H}, \mathrm{Me} ; \mathrm{R}^{2}=\mathrm{H}, \mathrm{Bu}^{t}, \mathrm{Br}$

$54 a-d$

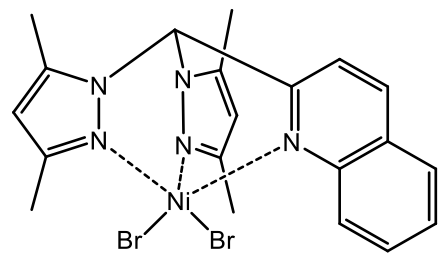

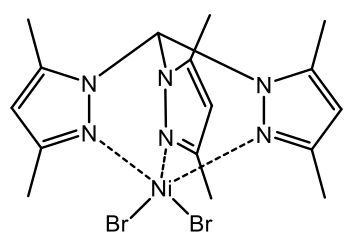

$\mathrm{TOF}=(2-12) \times 10^{3} \mathrm{~h}^{-1} ; \mathrm{S}\left(\Sigma \mathrm{C}_{4} \mathrm{H}_{8}\right)=90-99 \% ; \mathrm{C}\left(1-\mathrm{C}_{4} \mathrm{H}_{8}\right)=0-69 \%$ (in $\mathrm{C}_{4}$-fraction)

$\left(\mathrm{Et} 2 \mathrm{AlCl}, \mathrm{Al} / \mathrm{Ni}=75 ; 30^{\circ} \mathrm{C} ; 3\right.$ bar $)$

Figure 42. Nickel(II) complexes bearing heteroscorpionate ligands.

The introduction of ${ }^{t} \mathrm{Bu}$ at position 4 of pyrazole ring (54c) is accompanied by a decrease in activity from $12 \times 10^{3}$ to $10 \times 10^{3} \mathrm{~h}^{-1}$ due to an increase in the electron density at the metal center. The introduction of an electron-withdrawing Br-substituent (54d) at this position leads to an increase in selectivity for 1-butene from $16 \%$ to $60 \%$. Activity increases by $1.5-4.3$ times after addition to a catalytic system of 1 equivalent of $\mathrm{PPh}_{3}$. It is assumed that this is due to the reversible coordination of $\mathrm{PPh}_{3}$ to the Ni-center, which prevents the rearrangement of the complexes into thermodynamically more stable but catalytically inactive $\mathrm{L}_{2} \mathrm{Ni}^{\mathrm{II}}$ structures [88].

Casagrande et al. investigated zwitterionic complexes of the $\mathrm{NiCl}_{3} \mathrm{~L}$ type with pyrazolyl-ether -imidazolium ligands (55, Figure 43) [89]. 
<smiles></smiles>

$\mathrm{R}^{1}, \mathrm{R}^{2}, \mathrm{R}^{4}=\mathrm{H}, \mathrm{Me} ; \mathrm{R}^{3}=\mathrm{Me}, \mathrm{Bu}$

\author{
$\mathrm{TOF}=(2-8) \times 10^{3} \mathrm{~h}^{-1} ;$ \\ $\mathrm{S}\left(\Sigma \mathrm{C}_{4} \mathrm{H}_{8}\right)=94-98 \% ; \mathrm{S}\left(1-\mathrm{C}_{4} \mathrm{H}_{8}\right)=84-93 \%$ \\ (MAO, $\mathrm{Al} / \mathrm{Ni}=300 ; 30{ }^{\circ} \mathrm{C} ; 20$ bar $)$
}

55

Figure 43. Zwitterionic $\mathrm{Ni}^{\mathrm{II}}$ complexes with pyrazolyl-ether-imidazolium ligands.

The nickel center in these complexes is four-coordinated with distorted tetrahedral geometry. The positive charge of the imidazole fragment is neutralized by the negative charge of the third chloride ion bound to $\mathrm{Ni}^{\mathrm{II}}$. With the introduction of Me at position 2 of the imidazole fragment, the activity increases from $(2-3) \times 10^{3}$ to $(6-8) \times 10^{3} \mathrm{~h}^{-1}$. Lower activity in the case of unsubstituted imidazole fragment may be due to the reaction of hydrogen in position 2 with MAO. Variation of steric hindrance at the pyrazole ring has little influence on the distribution of products, in which 94-98\% are butenes [89].

In [90], it was proposed to use cationic methallyl nickel complexes bearing imidoyl-indazole ligands in ethylene dimerization (56, Figure 44).

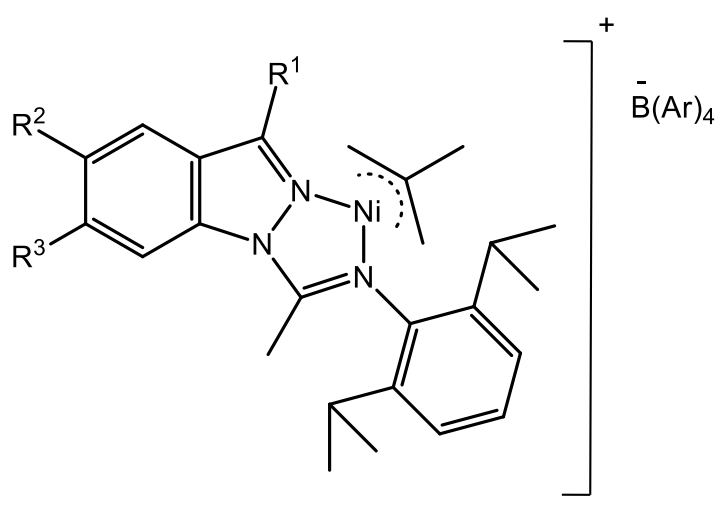

56a $\mathrm{R}^{1}=\mathrm{COOCH}_{3} ; \mathrm{R}^{2}=\mathrm{H} ; \mathrm{R}^{3}=\mathrm{H}$

$56 b \mathrm{R}^{1}=\mathrm{H} ; \mathrm{R}^{2}=\mathrm{H} ; \mathrm{R}^{3}=\mathrm{COOCH}_{3}$

Figure 44. Cationic methallyl nickel complexes bearing imidoyl-indazole ligands.

These complexes, after activation by $\mathrm{B}\left(\mathrm{C}_{6} \mathrm{~F}_{5}\right)_{3}$ (5 equivalents), have the activity of $0.02-0.04 \mathrm{~h}^{-1}$, and the selectivity for 1-butene/2-butene varies from $50 / 50 \%$ to $0 / 100 \%\left(20{ }^{\circ} \mathrm{C}, 1 \mathrm{bar}\right.$, solvent $\left.-\mathrm{CH}_{3} \mathrm{Cl}\right)$. The electron-withdrawing methoxycarbonyl group in the indazole ring (complex 56a) causes the formation of an electron-deficient metal center, which is active in ethylene oligomerization. The complexes are air-resistant: after $48 \mathrm{~h}$ of air exposure, they exhibit similar activity. In the case of a catalytic system based on $\mathbf{5 6} \mathbf{b}$ complex, with an increase in ethylene pressure to $12 \mathrm{bar}$, its activity increases to $14 \times 10^{3} \mathrm{~h}^{-1}$, the product is a low molecular weight polyethylene, in which $85 \%$ of the total branches are methyl [90].

\section{Nickel Complexes Bearing Hybrid Phosphorus and Nitrogen Containing Ligands}

Hybrid ligands, due to the combination of hard and soft electron-donors-nitrogen and phosphorus, respectively, have unique properties. Thus, due to the $\pi$-acceptor properties of the phosphorus atom, hybrid ligands can stabilize the metal in low oxidation states, and the $\sigma$-donor properties of the nitrogen atom cause greater susceptibility of the metal center to oxidative addition reactions. Therefore, these ligands can stabilize various oxidation states and the coordination geometry of the metal center during the 
catalytic cycle [91]. In addition, the weak interaction of the nitrogen atom with the metal center determines the hemilability of the hybrid ligand, which favors the stabilization of the active sites [92]. Varying the electronic and geometric configurations of nitrogen and phosphorus atoms in hybrid ligands provide great potential for fine tuning the catalytic properties of complexes based on them.

\subsection{Nickel(II) Complexes Bearing Phosphine and Phosphinite Ligands}

Group of C.J. Kamer investigated the dependence of the catalytic properties of pyridine-phosphine nickel complexes on the "bite angle" of the ligand, which is determined by the chemical nature of the fragment connecting pyridine and phosphine moieties (57, Figure 45) [93].<smiles></smiles>

57<smiles>c1ccc(Cc2ccccn2)cc1</smiles>

$57 \mathbf{a}$<smiles>c1ccc(CCc2ccccn2)cc1</smiles>

$57 \mathrm{~b}$<smiles>c1ccc(CCCc2ccccn2)cc1</smiles>

$57 \mathrm{c}$<smiles>c1ccc(-c2ccccc2-c2ccccc2)cc1</smiles>

$57 d$<smiles>CC12CC3C4C1C3(Pc1ccccc1)C42</smiles>

$57 e$

Bite angle for $\mathrm{LNiCl}_{2}$

$94.7^{\circ}$

$101.8^{\circ}$

$90.8^{\circ}$

$101.7^{\circ}$

(MAO, $\mathrm{Al} / \mathrm{Ni}=230 ; 30^{\circ} \mathrm{C} ; 10$ bar)

Figure 45. The "bite angles" of dichloride $\mathrm{Ni}^{\mathrm{II}}$ complexes with pyridine-phosphine ligands.

For these complexes, the "bite angle" is correlated with oligomerization activity-with an increase in this parameter from $87.2^{\circ}(57 \mathrm{a})$ to $101.8^{\circ}(57 \mathrm{c})$, the activity increases from $30 \times 10^{3}$ to $85 \times 10^{3} \mathrm{~h}^{-1}$. The 1-butene concentration decreases from $29 \%$ to $11 \%$, which indicates the increased isomerization activity of the complexes with expanding "bite angle". In [94,95] it was showed that a small "bite angle" prevents the migratory insertion of ethylene. However, for the complexes $57 \mathrm{~d}$ and $\mathbf{5 7 e}$, these patterns are not observed, which indicates the influence of additional factors-steric and electronic properties of the complex, flexibility of the ligand. For example, complex $57 \mathrm{~d}$ has a "bite angle" close to that for complex $\mathbf{5 7 b}$ (Figure 45 ), but its activity is 3 times higher. This is due to the structure of complex $\mathbf{5 7 d}$, which is flatter and more rigid [93].

The same group of authors also investigated the effect of the substituents at the phosphorus atom on the catalytic properties of pyridine-phosphine nickel(II) complexes (58, Figure 46) [96].

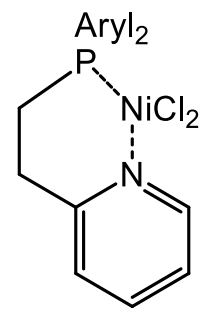
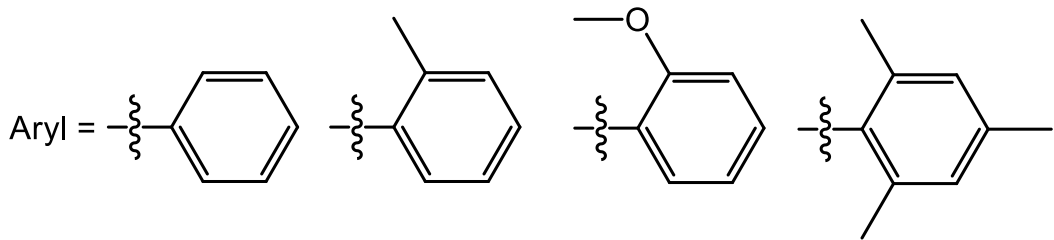

58

$$
\begin{gathered}
\text { TOF }=(14-70) \times 10^{3} \mathrm{~h}^{-1} ; \mathrm{S}\left(\Sigma \mathrm{C}_{4} \mathrm{H}_{8}\right)=78-95 \% ; \mathrm{C}\left(1-\mathrm{C}_{4} \mathrm{H}_{8}\right)=18-90 \% \text { (in } \mathrm{C}_{4} \text {-fraction) } \\
\left(\mathrm{MAO}, \mathrm{Al} / \mathrm{Ni}=230 ; 30{ }^{\circ} \mathrm{C} ; 10 \text { bar }\right)
\end{gathered}
$$

Figure 46. $\mathrm{Ni}^{\mathrm{II}}$ complexes bearing pyridine-phosphine ligands. 
In transition from Ph to 2-tolyl and Mes substituents at the phosphorus atom, the activity decreases from $70 \times 10^{3}$ to $(14-16) \times 10^{3} \mathrm{~h}^{-1}\left(\mathrm{MAO}, \mathrm{Al} / \mathrm{Ni}=200-230 ; 30^{\circ} \mathrm{C} ; 10 \mathrm{bar}\right)[96,97]$. However, the presence of bulkier substituents (2-tolyl, 2-anisyl, Mes) compared to Ph cause an increase in selectivity for 1-butene (from 18 to $46-90 \%$ ). At the same time, with the transition from 2-tolyl to bulkier 2-anisyl and Mes, selectivity for butenes increases from $78 \%$ to $93-95 \%$. This phenomenon can be explained by the fact that a branched alkyl chain, which formed after isomerization, requires more space around the metal center as compared to a linear chain. The presence of bulky substituents at phosphorus atom prevents the formation of bulky branched alkyl, but this also leads to lower activity of complexes with Mes. Higher activity $\left(65 \times 10^{3} \mathrm{~h}^{-1}\right)$ of the complex with a 2-anisyl substituent may be due to the coordination of the methoxy group to the nickel center [96].

The analogs of the above-considered pyridine-phosphine $\mathrm{Ni}^{\mathrm{II}}$ complexes, which have an aromatic substituent at the position 6 of pyridine ring, were synthesized and studied (59a-d, Figure 47) [98].

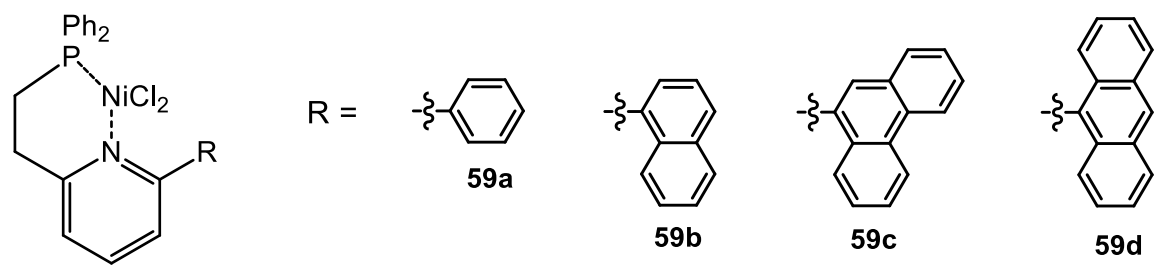

59

$\mathrm{TOF}=(3-11) \times 10^{3} \mathrm{~h}^{-1} ; \mathrm{S}\left(\Sigma \mathrm{C}_{4} \mathrm{H}_{8}\right)=93-97 \% ; \mathrm{C}\left(1-\mathrm{C}_{4} \mathrm{H}_{8}\right)=82-93 \%$ (in $\mathrm{C}_{4}$-fraction)

( $\mathrm{MAO}, \mathrm{Al} / \mathrm{Ni}=230 ; 30^{\circ} \mathrm{C} ; 10$ bar)

Figure 47. $\mathrm{Ni}^{\mathrm{II}}$ complexes bearing pyridine-phosphine ligands.

The introduction of the aromatic substituent into the position 6 of pyridine ring results in the activity reduction from $70 \times 10^{3}$ to $(3-11) \times 10^{3} \mathrm{~h}^{-1}$ and in the rise of butenes and 1-butene selectivities-from 86 to $93-97 \%$ and from $18 \%$ to $82-93 \%$, respectively $[93,98]$. In general, activity increases with the transition to a bulkier substituent-from $3 \times 10^{3}(\mathrm{Ph})$ to $11 \times 10^{3} \mathrm{~h}^{-1}$ (anthracyl). This may be due to a destabilization of the ground state as a result of the interaction of these substituents with nickel. The observed phenomenon indicates that the active species adopt a different conformation in the presence of an aromatic substituent at the position 6 of the pyridine ring. After the activation by MAO, a cationic complex is formed with a square-planar geometry around the nickel center. This leads to a greater influence of the substituents on the metal center [98].

The insertion of the oxygen atom into the $\mathrm{P}-\mathrm{CH}_{2}$ bond, which is accompanied by a change in the electronic and coordination state of the phosphorus atom, leads to slightly higher activity and selectivity for butenes of the resulting pyridine-phosphinite complex 61 (Figure 48) [97].<smiles></smiles>

60
$12 \times 10^{3}$

61

19

32<smiles>Cl[N+]1(c2ccccc2)OCc2cccc[n+]21</smiles>

61

$14 \times 10^{3}$

75

11

20<smiles></smiles>

62

$14 \times 10^{3}$

23

42

52

(MAO, $\mathrm{Al} / \mathrm{Ni}=100 ; 25-30^{\circ} \mathrm{C} ; 10 \mathrm{bar} ; 35 \mathrm{~min}$; solvent - mixture of $10 \mathrm{~mL}$ of $\mathrm{PhCl}$ and $4 \mathrm{ml}$ of $\mathrm{PhCH}_{3}$ )

Figure 48. $\mathrm{Ni}^{\mathrm{II}}$ complexes bearing pyridine-phosphine and pyridine-phosphinite ligands. 
Replacement of two $\mathrm{Ph}(\mathbf{6 1})$ at the phosphorus atom by more electron-donating substituent ${ }^{t} \mathrm{Bu}(\mathbf{6 2})$ does not lead to a change in activity, but at the same time selectivity for alpha-olefins increases, and the distribution of oligomers shifts from dimers to trimers. This is due to the predominance of 1-butene reinsertion over its isomerization. In the case of complex $\mathbf{6 2}$, the main isomer among the $\mathrm{C}_{6}$-oligomers is 2-ethyl-1-butene (75\% of $\left.\sum \mathrm{C}_{6} \mathrm{H}_{12}\right)$-the product of 1-butene reinsertion. In the case of complex 61, $68 \%$ of hexenes are the products of the reaction between ethylene and 2-butene (Figure 49) $[97,99]$.

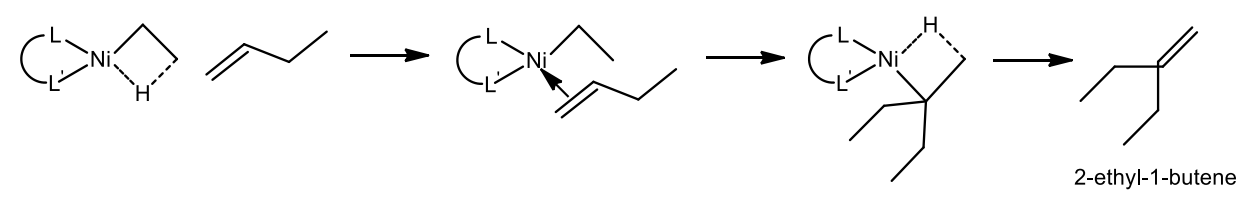

Figure 49. Reinsertion of 1-butene, accompanied by the formation of 2-ethyl-1-butene.

In the phosphine complex, replacement of pyridine by less basic oxazoline (63) or thiazoline (64) leads to an increase in activity at a close oligomer ratio, which follows the Schulz-Flory distribution (Figure 50) [100].<smiles>ClN1[N+]2CC=CC=C2C[PH]1(Cl)Cl</smiles>

60<smiles>[R7]C1=C2OCCN2C1(Cl)Cl</smiles>

63

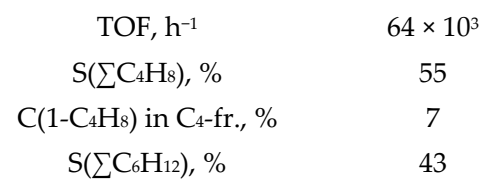<smiles>[R7]C1=NCCS1</smiles>

64

$72 \times 10^{3}$

58

4

39

(EtAlCl $2, \mathrm{Al} / \mathrm{Ni}=6 ; 25-30^{\circ} \mathrm{C} ; 10$ bar; $35 \mathrm{~min}$; solvent-mixture of $12 \mathrm{ml} \mathrm{PhCl}$ and $3 \mathrm{ml} \mathrm{PhCH}_{3}$ )

Figure 50. $\mathrm{Ni}^{\mathrm{II}}$ complexes bearing pyridine-phosphine, oxazoline-phosphine and thiazolinephosphine ligands.

Upon transition from N,P- to symmetric N,P,N-ligands, the activity decreases from $64 \times 10^{3}$ to $56 \times 10^{3} \mathrm{~h}^{-1}$ in the case of pyridine-phosphine complex 65 , and from $59 \times 10^{3}$ to $50 \times 10^{3} \mathrm{~h}^{-1}$ in the case of pyridine-phosphinite complex 66 (Figure 51) [97,101].<smiles></smiles>

65<smiles></smiles>

66

$$
\begin{gathered}
\mathrm{TOF}=56 \times 10^{3} \mathrm{~h}^{-1} ; \mathrm{S}\left(\Sigma \mathrm{C}_{4} \mathrm{H}_{8}\right)=53 \% ; \\
\mathrm{C}\left(1-\mathrm{C}_{4} \mathrm{H}_{8}\right)=8 \% \text { (in } \mathrm{C}_{4} \text {-fraction) }
\end{gathered}
$$

(a)

$$
\begin{gathered}
\mathrm{TOF}=50 \times 10^{3} \mathrm{~h}^{-1} ; \mathrm{S}\left(\Sigma \mathrm{C}_{4} \mathrm{H}_{8}\right)=53 \% ; \\
\mathrm{C}\left(1-\mathrm{C}_{4} \mathrm{H}_{8}\right)=13 \% \text { (in } \mathrm{C}_{4} \text {-fraction) }
\end{gathered}
$$

(b)

$\left(\mathrm{EtAlCl}_{2}, \mathrm{Al} / \mathrm{Ni}=6 ; 30^{\circ} \mathrm{C} ; 10\right.$ bar; $35 \mathrm{~min}$; solvent - mixture $12 \mathrm{~mL}$ of $\mathrm{PhCl}$ and $3 \mathrm{ml}$ of $\mathrm{PhCH}_{3}$ )

Figure 51. $\mathrm{Ni}^{\mathrm{II}}$ complexes bearing tridentate $\mathrm{N}, \mathrm{P}, \mathrm{N}$-ligands: pyridine-phosphine (a) and pyridinephosphinite (b). 
Dyer and co-workers tested in ethylene oligomerization the $\mathrm{Ni}^{\mathrm{II}}$ complexes with $\mathrm{N}$-phosphino guanidine ligands (67, Figure 52) [102].

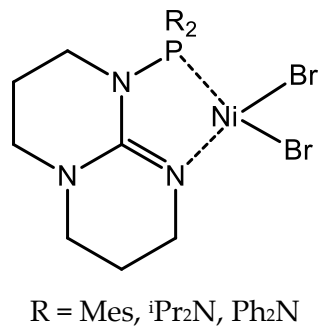

67

\author{
$\mathrm{TOF}=(2-5) \times 10^{3} \mathrm{~h}^{-1} ;$ \\ $\mathrm{S}\left(\Sigma \mathrm{C}_{4} \mathrm{H}_{8}\right)=55-85 \% ; \mathrm{S}\left(1-\mathrm{C}_{4} \mathrm{H}_{8}\right)=4-13 \%$ \\ $\left(\mathrm{EtAlCl}_{2}, \mathrm{Al} / \mathrm{Ni}=14 ; 25-30^{\circ} \mathrm{C} ; 1\right.$ bar $)$
}

Figure 52. $\mathrm{Ni}^{\mathrm{II}}$ complexes with $\mathrm{N}$-phosphino guanidine ligands.

The complex with a diphenylamino substituents having the lowest $\sigma$-donor ability of the phosphorus atom possesses the lowest activity $\left(2 \times 10^{3} \mathrm{~h}^{-1}\right)$ and selectivity for butenes (55\%). On the contrary, the complex with diisopropylamine substituents and phosphorus atom with greater Lewis basicity possesses both the highest activity $\left(5 \times 10^{3} \mathrm{~h}^{-1}\right)$ and selectivity for butenes $(85 \%)$ [102].

De Souza et al. developed $\mathrm{Ni}^{\mathrm{II}}$ complexes bearing 2-pyridylphosphole derivatives (68, Figure 53), and tested them in ethylene oligomerization [103].

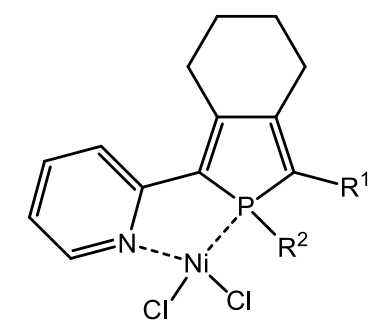

$\mathrm{R}^{1}=\mathrm{Ph}$, 2-thienyl; $\mathrm{R}^{2}=\mathrm{Ph}, \mathrm{Cy}$

\author{
$\mathrm{TOF}=(7-12) \times 10^{3} \mathrm{~h}^{-1} ;$ \\ $\mathrm{S}\left(\Sigma \mathrm{C}_{4} \mathrm{H}_{8}\right)=71-89 \% ; \mathrm{S}\left(1-\mathrm{C}_{4} \mathrm{H}_{8}\right)=1-2 \%$; \\ $\mathrm{S}\left(\Sigma \mathrm{C}_{6} \mathrm{H}_{12}\right)=11-24 \% ; \mathrm{C}\left(1-\mathrm{C}_{6} \mathrm{H}_{12}\right)=1-2 \%$; \\ $\left(\mathrm{Et}_{2} \mathrm{AlCl}, \mathrm{Al} / \mathrm{Ni}=70 ; 0{ }^{\circ} \mathrm{C} ; 1\right.$ bar; $\left.60 \mathrm{~min}\right)$
}

68

Figure 53. $\mathrm{Ni}^{\mathrm{II}}$ complexes bearing 2-pyridylphosphole ligands.

Changing of $\mathrm{Ph}$ at the phosphorus atom to bulkier $\mathrm{Cy}$ does not significantly affect the activity $\left(8 \times 10^{3}\right.$ and $7 \times 10^{3} \mathrm{~h}^{-1}$, respectively, for complexes with $\mathrm{R}^{1}=\mathrm{Ph}$; and $12 \times 10^{3} \mathrm{~h}^{-1}$ for both complexes, with $\mathrm{R}^{1}=2$-thienyl), but leads to an increase in the yield of $\mathrm{C}_{6+}$ oligomers (by 7-8\%). An increase in steric hindrances at the phosphorus atom, in combination with steric hindrances created by pyridyl fragment, causes a decrease in the rate of $\beta$-elimination of 1-butene, which is favorable for chain growth by insertion of ethylene molecules through the Ni-C bond [103]. A similar phenomenon of suppression of the elimination process was observed for ethylene polymerization on nickel diimine complexes with bulky substituents at nitrogen atoms [17].

The introduction of a substituent with a higher electron-donor ability (2-thienyl instead of $\mathrm{Ph}$ ) at the alpha-position of the phosphole fragment, causes an increase in the activity of complexes from $(7-8) \times 10^{3}$ to $12 \times 10^{3} \mathrm{~h}^{-1}$ and in the selectivity for butenes from $71-79 \%$ to $82-89 \%$.

For the complexes under consideration, an increase in the oligomerization pressure from 1 to 41 bar is accompanied by an increase in selectivity for 1-butene from 1\% to $73-80 \%$ with an almost constant selectivity for butenes (89-97\%). A probable reason is the predominance of the chain transfer to ethylene over the isomerization of nickel bonded butyl at increased ethylene pressure (Figure 54) [103]. 


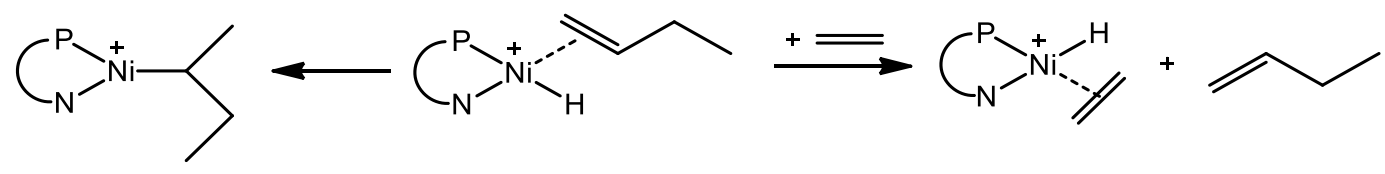

Figure 54. Chain transfer to ethylene and isomerization of nickel bonded alkyl chain.

\subsection{Nickel Complexes with Phosphinito-Imine Ligands}

Campora and co-workers synthesized and studied $\mathrm{Ni}^{\mathrm{II}}$ complexes with phosphinito-imine ligands (69, Figure 55) [104].<smiles>[R]C1=[N+](c2c([R7])cccc2[R])N(Br)[PH]([R1])([R1])O1</smiles>

$\mathrm{R}^{1}={ }^{i} \mathrm{Pr} ;{ }^{t} \mathrm{Bu} ; \mathrm{R}^{2}=\mathrm{Me} ;{ }^{t} \mathrm{Bu}$

\author{
$\mathrm{TOF}=(10-78) \times 10^{3} \mathrm{~h}^{-1} ;$ \\ $\mathrm{S}\left(\Sigma \mathrm{C}_{4} \mathrm{H}_{8}\right)=75-90 \%$; \\ $\mathrm{C}\left(1-\mathrm{C}_{4} \mathrm{H}_{8}\right)=17-48 \%$ (in $\mathrm{C}_{4}$-fraction); \\ $\mathrm{S}\left(\mathrm{C}_{6} \mathrm{H}_{12}\right)=10-23 \%$; \\ $\mathrm{S}\left(\Sigma \mathrm{C}_{8} \mathrm{H}_{16}\right)=1-2 \%$ \\ $\left(\mathrm{Et}_{2} \mathrm{AlCl}, \mathrm{Al} / \mathrm{Ni}=176-1192 ; 30^{\circ} \mathrm{C} ; 5\right.$ bar; $\left.60 \mathrm{~min}\right)$
}

69

Figure 55. $\mathrm{Ni}^{\mathrm{II}}$ complexes with phosphinito-imine ligands.

An oxygen atom was introduced between the nitrogen and phosphorus atoms to prevent the enolization process (Figure 56), which causes low stability of the complex [105].

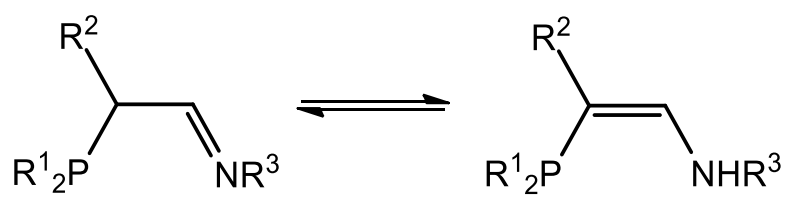

Figure 56. Enolization of imino-phosphine.

The activity and selectivity for butene of complex 69 are significantly affected by the substituents at the phosphorus atom and is almost independent of the substituent at the carbon atom of the imine moiety (Figure 55). Thus, in the transition from two ${ }^{i} \mathrm{Pr}$ to two ${ }^{t} \mathrm{Bu}$ at the phosphorus atom, the activity decreases from $78 \times 10^{3}$ to $10 \times 10^{3} \mathrm{~h}^{-1}$, and the selectivity for butenes increases from $80 \%$ to $90 \%$. The complex with Me at the carbon atom of the imine moiety has the activity close to that of the complex with ${ }^{t} \mathrm{Bu}-78 \times 10^{3}$ and $74 \times 10^{3} \mathrm{~h}^{-1}$, respectively [104].

\subsection{Nickel Complexes with Phosphinoiminophosphorane Ligands}

Le Floch and co-workers developed nickel(II) complexes with phosphinoiminophosphorane ligands (70-72, Figure 57) [106].

With the transition from five-membered to six-membered complexes, selectivity for 1-butene decreases from $77-86 \%$ to $55-68 \%$. A rigid six-membered chelate ring with phenylene between phosphorus atoms $(71)$ causes two times higher activity $\left(97 \times 10^{3}\right.$ vs. $\left.45 \times 10^{3} \mathrm{~h}^{-1}\right)$ compared to a flexible five-membered chelate ring with a methylene bridge between phosphorus atoms (70). However, the selectivity for 1-butene of complex $\mathbf{7 1}$ is less than that of complex $\mathbf{7 0}$ (68\% vs. 83\%). In the case of a flexible six-membered chelate ring (with a $-\mathrm{CH}_{2}-\mathrm{CH}_{2}-$ bridge between phosphorus atoms), lower activity is observed compared to a rigid chelate ring $-44 \times 10^{3} \mathrm{~h}^{-1}$. In the transition 
from ${ }^{i} \mathrm{Pr}$ to a bulkier ${ }^{t} \mathrm{Bu}$ at the nitrogen atom, the activity decreases significantly-from $107 \times 10^{3}$ to $21 \times 10^{3} \mathrm{~h}^{-1}[106]$.<smiles>[R]N1[N+](Br)(Br)[PH](c2ccccc2)(c2ccccc2)CP1(Br)(Br)c1ccccc1</smiles>

$\mathrm{R}=\mathrm{CH}_{2}-\mathrm{Bu}^{t}, \mathrm{p}-\mathrm{CH}_{2}-\mathrm{C}_{6} \mathrm{H}_{4} \mathrm{OMe}, \mathrm{Ph}$

70<smiles>[R]N1[N+](Br)(Br)C([R1])([R])c2ccccc2P1(=O)c1ccccc1</smiles>

71<smiles></smiles>

72

$\mathrm{TOF}=(21-107) \times 10^{3} \mathrm{~h}^{-1} ; \mathrm{S}\left(\Sigma \mathrm{C}_{4} \mathrm{H}_{8}\right)=90-98 \% ; \mathrm{C}\left(1-\mathrm{C}_{4} \mathrm{H}_{8}\right)=55-83 \%$ (in $\mathrm{C}_{4}$-fraction)

(MAO, $\mathrm{Al} / \mathrm{Ni}=300 ; 45^{\circ} \mathrm{C} ; 30$ bar)

Figure 57. $\mathrm{Ni}^{\mathrm{II}}$ complexes with phosphinoiminophosphorane ligands.

Mono- and bimetallic complexes with iminophosphorane-phenoxide ligands (73-76, Figure 58) were presented by Auffrant et al. [107].

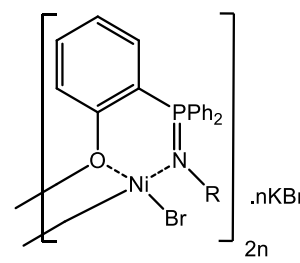

$73 a-c$

a $\mathrm{R}={ }^{\mathrm{t}} \mathrm{Bu}$

b $\mathrm{R}=\mathrm{CH}_{2} \mathrm{C}\left(\mathrm{CH}_{3}\right)_{3}$

$\mathrm{c} \mathrm{R}=\mathrm{Ph}$<smiles>BrC12Nc3ccccc3N1c1ccccc1O2</smiles>

$73 d$

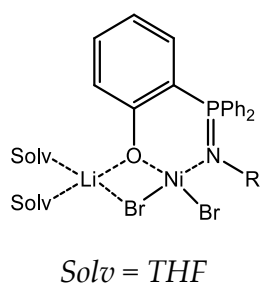

$74 a-c$

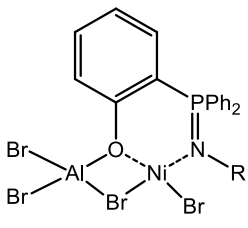

$75 a-c$

a $\mathrm{R}={ }^{t} \mathrm{Bu}$

b $\mathrm{R}=\mathrm{CH}_{2} \mathrm{C}\left(\mathrm{CH}_{3}\right)_{3}$

c $\mathrm{R}=\mathrm{Ph}$

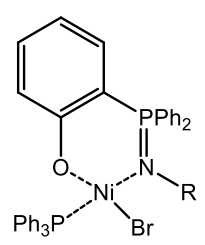

$76 a-c$

$\mathrm{TOF}=(7-68) \times 10^{3} \mathrm{~h}^{-1} ; \mathrm{S}\left(\Sigma \mathrm{C}_{4} \mathrm{H}_{8}\right)=97-100 \% ; \mathrm{C}\left(1-\mathrm{C}_{4} \mathrm{H}_{8}\right)=42-94 \%$ (in $\mathrm{C}_{4}$-fraction)

$\left(\mathrm{Et}_{2} \mathrm{AlCl}, \mathrm{Al} / \mathrm{Ni}=22.5 ; 25^{\circ} \mathrm{C} ; 30 \mathrm{bar} ; 60 \mathrm{~min}\right)$

Figure 58. Mono- and bimetallic complexes with iminophosphorane-phenoxide ligands.

The formation of oligomers with a carbon number of more than 6 was not observed during ethylene oligomerization. The highest selectivity for 1-butene has nickel-lithium and nickel-aluminum bimetallic systems-74a-c (73-83\%) and 75a-c (82-94\%), respectively, and the lowest-monometallic ones 76a-c (42-56\%) [107]. The presented systems are comparable in activity with activated phenyl ether-pyrazolyl complexes 37 (Figure 30) but have a longer lifetime-60 vs. $20 \mathrm{~min}[75,107]$.

In a series of nickel-potassium bimetallic complexes (73a-c, Figure 58), the system with $\mathrm{Ph}$ at the nitrogen atom is more active than with ${ }^{t} \mathrm{Bu}$, which is due to its lower electron-donor ability and, accordingly, lower electron density at nitrogen atom and a lower degree of ligand coordination to the nickel [107].

Heinicke and co-workers developed a number of phosphino-amino acids, which is used as ligands of SHOP-type catalytic systems [108-110]. For example, $\alpha$-diphenylphosphino-N-(pyrazin-2-yl)glycine (77, Figure 59) in composition with $\mathrm{Ni}(\mathrm{COD})_{2}$, where $\mathrm{COD}-1,5$-cyclooctadiene, oligomerizes ethylene mainly to 1-butene (24-46\%) and to 1-hexene (14-26\%) [111]. 
<smiles>O=C(O)C(Nc1cnccn1)Pc1ccccc1</smiles>

(a)<smiles>O=C1O[NH+]PC1Nc1cnccn1</smiles>

(b)

Figure 59. $\alpha$-Diphenylphosphino-N-(pyrazin-2-yl)glycine (a) and proposed Ni-H complex bearing this ligand (b).

\section{Diphosphine Nickel Complexes}

Recently, diphosphine ligands gained considerable attention due to the high ability of these compounds to coordinate with metal atoms. For example, in the case of bis(phosphanyl)amine ligands with PNP structure, varying the $\mathrm{P}-\mathrm{N}-\mathrm{P}$ angle and electron-donor properties of phosphorus atoms by introducing different substituents creates vast possibilities for fine tuning the complex characteristics to optimal for ethylene oligomerization [112]. This is confirmed by a large number of effective catalytic systems for ethylene trimerization based on chromium complexes with P,N,P-ligands developed over the past decade [113]. However, there is also a number of works describing the synthesis of nickel complexes with $\mathrm{P}, \mathrm{N}, \mathrm{P}$-ligands and their application as pre-catalyst for ethylene oligomerization.

\subsection{Nickel(II) Complexes with $\mathrm{N}$ - and Si-Bridged Diphosphine Ligands}

$\mathrm{Wu}$ and co-workers studied the effect of nitrogen functionalization in the symmetrical P,N,P-ligand by introducing different electron-donor groups (78, Figure 60) [114]. It was found out that the Lewis base group favors ethylene insertion as it can be concluded from increased activity of complexes with more basic N-functionalized ligands (from $10 \times 10^{3}$ to $13 \times 10^{3} \mathrm{~h}^{-1}$ in order of benzyl- < furfuryl- < thiophene-2-methyl- $<2$-picolyl-substituted ligands). The effect of the substituent at nitrogen atoms on the catalytic properties of complexes is caused by their coordination to the activated nickel center.

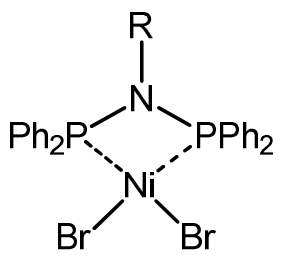

$$
\mathrm{R}=\left\{\begin{array}{l}
\mathrm{CH}_{2}\left(\mathrm{C}_{6} \mathrm{H}_{5}\right) \\
\mathrm{CH}_{2}\left(\mathrm{C}_{4} \mathrm{H}_{3} \mathrm{O}\right) \\
\mathrm{CH}_{2}\left(\mathrm{C}_{4} \mathrm{H}_{3} \mathrm{~S}\right) \\
\mathrm{CH}_{2}\left(\mathrm{C}_{5} \mathrm{H}_{4} \mathrm{~N}\right) \\
\mathrm{CH}_{2} \mathrm{CH}_{2}\left(\mathrm{C}_{4} \mathrm{H}_{3} \mathrm{~S}\right)
\end{array}\right.
$$

78

Figure 60. $\mathrm{Ni}^{\mathrm{II}}$ complexes with bis(phosphanyl)amine ligands.

Nickel(II) complexes bearing bis(diphenylphosphino)(N-thioether)amine ligands (79-82, Figure 61) were studied by Braunstein et al. [115]. Both complexes, with a four- and five-membered chelate ring, have square-planar geometry around the nickel center.

Using DFT calculations it was confirmed that the presence of sulfur bound to the phosphorus atom decreases thermodynamic stability of nickel complexes due to decreased electron-donor properties of $\mathrm{P}=\mathrm{S}$ moiety, despite the fact that five-membered chelates are usually more stable than four-membered ones. Nevertheless, the insertion of sulfur in the chelate ring significantly influences the catalytic properties of the $\mathrm{Ni}^{\mathrm{II}}$ complexes in the ethylene oligomerization process. Thus, the complex 82 displays $1.8-3.3$ times lower activity compared to 81 , but higher selectivity for butenes (82-87\% vs. $58-69 \%)$. The opposite result is obtained using $\mathrm{N}-\left(\mathrm{CH}_{2}\right)_{3} \mathrm{SMe}$ substituted ligands: in the transition from complex 79 to 80 , the activity increases $1.2-1.3$ times, and the selectivity for butenes decreases from $70-71 \%$ to $66-71 \%$ [115]. 

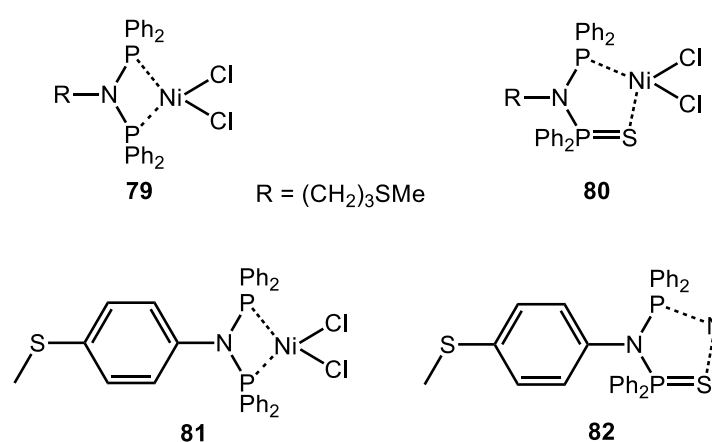

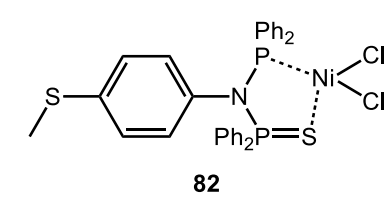

$$
\begin{gathered}
\mathrm{TOF}=(27-48) \times 10^{3} \mathrm{~h}^{-1} ; \\
\mathrm{S}\left(\Sigma \mathrm{C}_{4} \mathrm{H}_{8}\right)=69-82 \% ;
\end{gathered}
$$

$\mathrm{C}\left(1-\mathrm{C}_{4} \mathrm{H}_{8}\right)=4-17 \%$ (in $\mathrm{C}_{4}$-fraction)

(EtAlCl $2, \mathrm{Al} / \mathrm{Ni}=10 ; 28-30{ }^{\circ} \mathrm{C} ; 10$ bar;

solvent- $\mathrm{PhCl}$ )

Figure 61. Nickel(II) complexes with bis(diphenylphosphino)(N-thioether)amine ligands.

Jiang and co-workers studied $\mathrm{Ni}^{\mathrm{II}}$ complexes with Si-bridged diphosphine ligands (83-85, Figure 62) in ethylene oligomerization [116].<smiles>C[Si]1(C)[Si](Br)(c2ccccc2)[N+](Br)(c2ccccc2)P1(Br)(c1ccccc1)c1ccccc1</smiles>

83<smiles>C[Si]1(C)CP(c2ccccc2)(c2ccccc2)(c2ccccc2)P(Br)(Br)(c2ccccc2)[N+]1(Br)c1ccccc1</smiles>

84<smiles>C[Si]1(C)C[N+](Br)(c2ccccc2)P(c2ccccc2)(c2ccccc2)(c2ccccc2)C1</smiles>

85

$$
\begin{gathered}
\text { TOF }=10 \times 10^{3} \mathrm{~h}^{-1} ; \\
\mathrm{S}\left(\Sigma \mathrm{C}_{4} \mathrm{H}_{8}\right)=98 \% ; \mathrm{S}\left(1-\mathrm{C}_{4} \mathrm{H}_{8}\right)= \\
26 \%
\end{gathered}
$$

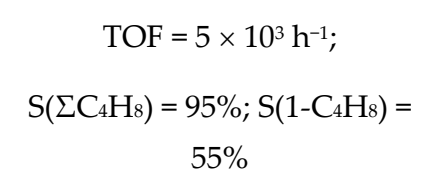

(MAO, $\mathrm{Al} / \mathrm{Ni}=700 ; 30{ }^{\circ} \mathrm{C} ; 10$ bar; $\left.30 \mathrm{~min}\right)$

Figure 62. $\mathrm{Ni}^{\mathrm{II}}$ complexes with Si-bridged diphosphine ligands.

Complex 83, being the analog of bis(phosphanyl)amine complex 78 (Figure 60), exhibits relatively close activity compared to the latter, but only under conditions of 20 times increased pressure (10 bar vs. $0.5 \mathrm{bar}$ ) and higher $\mathrm{Al} / \mathrm{Ni}$ ratio (700 and 400 equivalents, respectively). However, 83 is more selective for butenes ( $98 \%$ vs. $77 \%$ ), but less selective for 1-butene-26\% vs. $49 \%$. Complex 83 is more thermally stable: its activity increases from $10 \times 10^{3}$ to $45 \times 10^{3} \mathrm{~h}^{-1}$ with an elevation of the reaction temperature from $30{ }^{\circ} \mathrm{C}$ to $75{ }^{\circ} \mathrm{C}$ (however, the selectivity for butenes decreases from $98 \%$ to $85 \%$ ). In the case of the complex 78 , the elevation of the reaction temperature to $50^{\circ} \mathrm{C}$ leads to a shift from oligomerization towards toluene alkylation by ethylene and obtained oligomers. Chelate ring expansion from four-membered $\mathbf{8 3}$ to five-membered $\mathbf{8 4}$ increases the activity; however, the further increase in the ring size to a six-membered 85 decreases the activity [116].

In [117] nickel(II) complexes bearing silicon-bridged diphosphine amine ligands were presented (86, Figure 63).

The complex with the bulkiest substituent (DiPP) at the $\mathrm{N}$-atom possesses the highest selectivity for 1-butene $(88 \%)$ and the lowest activity $\left(73 \times 10^{3} \mathrm{~h}^{-1}\right)$ [117]. For this complex, the elevation of the reaction temperature from 30 to $75^{\circ} \mathrm{C}$ is accompanied by a reduction of the selectivity for 1-butene, its content in $\mathrm{C}_{4}$-fraction decreases from $88 \%$ to $63 \%$. A similar pattern of a decrease in alpha-olefin selectivity with an elevation of oligomerization temperature was observed in [118]. 
<smiles></smiles>

$\mathrm{R}=$ Pr, cyclopentyl, DiPP (2,6-diisopropylphenyl)

\author{
$\mathrm{TOF}=(73-814) \times 10^{3} \mathrm{~h}^{-1} ;$ \\ $\mathrm{S}\left(\Sigma \mathrm{C}_{4} \mathrm{H}_{8}\right)=77-96 \%$ \\ $\mathrm{C}\left(1-\mathrm{C}_{4} \mathrm{H}_{8}\right)=42-88 \%$ (in $\mathrm{C}_{4}$-fraction) \\ $\left(\mathrm{EtAlCl}_{2}, \mathrm{Al} / \mathrm{Ni}=500 ; 30^{\circ} \mathrm{C} ; 10\right.$ bar; \\ solvent - methylcyclohexane)
}

86

Figure 63. $\mathrm{Ni}^{\mathrm{II}}$ complexes with Si-bridged diphosphe amine ligands.

Until recently, the development of nickel complexes with asymmetric P,N,P-ligands has been limited by the lack of methods for their synthesis. Olivier-Bourbigou and co-workers proposed a new method for the synthesis of complexes with non-symmetrical diphosphinoamine ligands using sulfonamide moieties $\left[\mathrm{R}^{1} \mathrm{SO}_{2}-\mathrm{N}=\mathrm{P}\left(\mathrm{R}^{2}\right)_{2}-\mathrm{P}\left(\mathrm{R}^{3}\right)_{2}\right]$ (87, Figure 64) [119].<smiles>[R]P([R])P([R])([R])=NS([R])(=O)=O</smiles>

87

$$
\begin{gathered}
\mathrm{R}^{1}=(4-\mathrm{Br}) \mathrm{C}_{6} \mathrm{H}_{4},(4-\mathrm{Bu}) \mathrm{C}_{6} \mathrm{H}_{4} ; \mathrm{R}^{2}={ }^{i} \mathrm{Pr}, \mathrm{Ph} ; \mathrm{R}^{3}={ }^{i} \mathrm{Pr}, \mathrm{Cy}, \mathrm{Ph} \\
\mathrm{TOF}=(29-170) \times 10^{3} \mathrm{~h}^{-1} ; \mathrm{S}\left(\Sigma \mathrm{C}_{4} \mathrm{H}_{8}\right)=68-92 \% ; \mathrm{C}\left(1-\mathrm{C}_{4} \mathrm{H}_{8}\right)=21-58 \% \text { (in } \mathrm{C}_{4} \text {-fraction) } \\
\left(\mathrm{MAO}, \mathrm{Al} / \mathrm{Ni}=300 ; 45^{\circ} \mathrm{C} ; 30 \text { bar; } 60 \mathrm{~min}\right)
\end{gathered}
$$

Figure 64. Synthesis of non-symmetrical diphosphinoamine $\mathrm{Ni}^{\mathrm{II}}$ complexes.

The advantage of using a sulfonyl group appears in the stabilization of reagents, which allowed the synthesis of a variety of homo- and hetero-substituted nickel complexes including ones with basic phosphines. Nickel complexes have a square-planar geometry with a constrained cis-coordination of the ligand. P-alkyl substituted complexes displayed 5-6 times higher activity than the complex with a ligand containing two $\mathrm{P}(\mathrm{Ph})_{2}$ groups. Beside butenes, $7-19 \%$ of hexenes are formed in the process of ethylene oligomerization. In $\mathrm{C}_{6}$-fraction, methylpentenes are the predominant isomers, which are likely formed as a result of co-dimerisation reactions between ethylene and butenes. The analysis of products after $12 \mathrm{~min}$ and $60 \mathrm{~min}$ of the oligomerization process showed that the co-dimerization proceeds parallel to oligomerization from the start of the reaction. Compared to the analogs 79-82, complexes 87 showed close activity and selectivity for butenes, but higher selectivity for 1-butene [119].

Compared to 86, the complexes bearing ethylene-bridged diphosphine ligands 88 and 89 (Figure 65) possess much lower activity- $(4-11) \times 10^{3} \mathrm{~h}^{-1}$, and close selectivity for butenes (79-93\%) [119].<smiles>P[Pb]1CCP[N+]1(Cl)Cl</smiles>

88

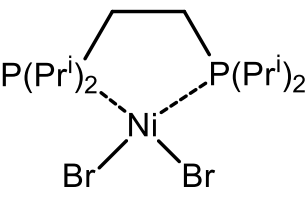

89

Figure 65. Diphosphine $\mathrm{Ni}^{\mathrm{II}}$ complexes. 


\subsection{Nickel(II) Complexes with Xantphos-Type Ligands}

Xanthene-based ligands gained great interest due to their rigid backbone and the exceptionally large bite angle which are the important parameters for the metal stabilization and preparation of highly active homogeneous catalysts [95,120].

Le Floch and co-workers synthesized $\mathrm{Ni}^{\mathrm{II}}$ complexes with phosphole- and phosphine-xanthene ligands (90 and 91, respectively, Figure 66) [121].

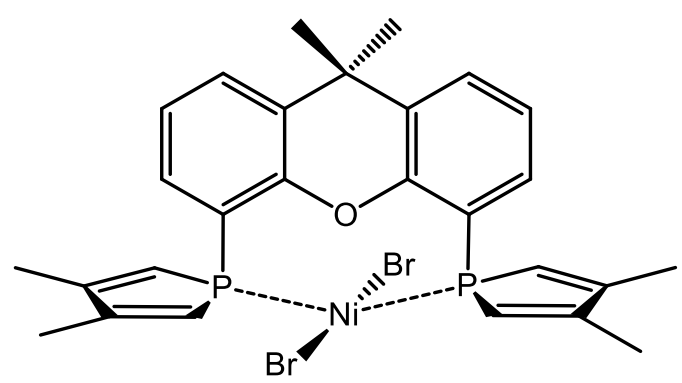

90

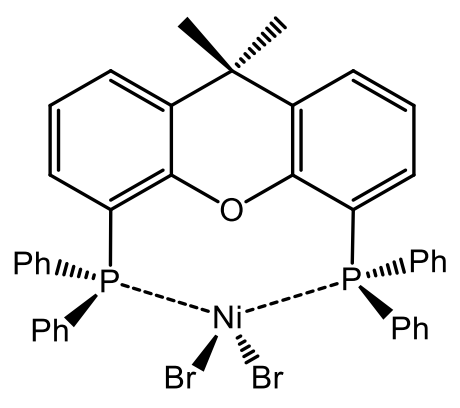

91

$$
\begin{array}{cc}
\text { TOF }=43 \times 10^{3} \mathrm{~h}^{-1} ; & \text { TOF }=14 \times 10^{3} \mathrm{~h}^{-1} ; \\
\mathrm{S}\left(\Sigma \mathrm{C}_{4} \mathrm{H}_{8}\right)=97 \% ; \mathrm{S}\left(1-\mathrm{C}_{4} \mathrm{H}_{8}\right)=90 \% & \mathrm{~S}\left(\Sigma \mathrm{C}_{4} \mathrm{H}_{8}\right)=96 \% ; \mathrm{S}\left(1-\mathrm{C}_{4} \mathrm{H}_{8}\right)=88 \%
\end{array}
$$

( $\mathrm{MAO}, \mathrm{Al} / \mathrm{Ni}=300 ; 20^{\circ} \mathrm{C} ; 30$ bar)

Figure 66. $\mathrm{Ni}^{\mathrm{II}}$ complexes with xanthphos-type ligands.

The complex 90 with bis(phosphole) ligand is more active than the bis(phosphine) complex 91, while the latter possesses catalytic properties very close to a dimethoxyethane (DME) $\mathrm{Ni}^{\mathrm{II}}$ complex $\left[\mathrm{NiBr}_{2}(\mathrm{DME})\right]$. This fact indicates that the ligand decoordination may occur during the oligomerization process [121].

\subsection{Nickel Complexes with Supramolecular Diphosphine Ligands}

Olivier-Bourbigou et al. synthesized self-assembled nickel complexes based on sulfonamidophosphorus and aminophosphine ligands (92, Figure 67) [122].<smiles>[R]P([R])([CH2+])=NS(C)(=O)=O</smiles>

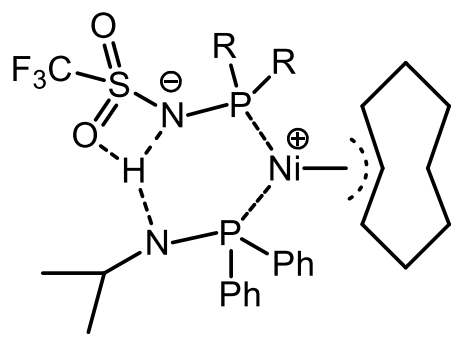

92

$$
\mathrm{R}=i \operatorname{Pr}, \mathrm{o}-\mathrm{tolyl}
$$

$\mathrm{TOF}=(25-50) \times 10^{3} \mathrm{~h}^{-1} ; \mathrm{S}\left(\Sigma \mathrm{C}_{4} \mathrm{H}_{8}\right)=35-85 \% ; \mathrm{C}\left(1-\mathrm{C}_{4} \mathrm{H}_{8}\right)=99-100 \%$ (in $\mathrm{C}_{4}$-fraction)

Figure 67. Preparation of self-assembled nickel complexes.

A hydrogen bond between the N,S,O-center of the sulfonamido-phosphorus ligand and the $\mathrm{NH}$-group of the aminophosphine ligand enhances the stability of complex 92 during ethylene dimerization reactions. Notably, these complexes catalyze ethylene dimerization even in the absence of any additional activator [122]. 
The same research group also proposed new self-assembled $\pi$-allylic nickel complexes bearing secondary phosphine oxide ligands (93, Figure 68) [123].

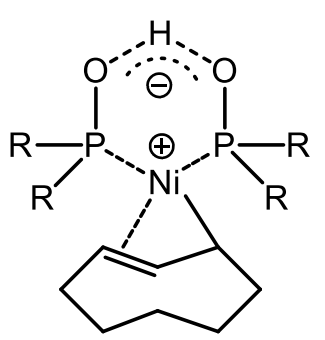

93

$$
R=\left\{\begin{array}{l}
\mathrm{Ph} \\
4-\mathrm{CF}_{3}\left(\mathrm{C}_{6} \mathrm{H}_{4}\right)^{-} \\
4-\mathrm{OMe}\left(\mathrm{C}_{6} \mathrm{H}_{4}\right)- \\
2-\mathrm{Me}\left(\mathrm{C}_{6} \mathrm{H}_{4}\right)^{-} \\
\left(\mathrm{C}_{6} \mathrm{H}_{5}\right) \mathrm{CH}_{2}- \\
\mathrm{CH}_{3}\left(\mathrm{CH}_{2}\right)_{5}
\end{array}\right.
$$

$90 \mathrm{~min})$

Figure 68. Supramolecular $\pi$-allylic nickel complexes with secondary phosphine oxide ligands.

Nickel has square-planar coordination in these complexes. The addition of Lewis acid $B\left(\mathrm{C}_{6} \mathrm{~F}_{5}\right)_{3}$ leads to a formation of the zwitterionic dissymmetric borate adduct (Figure 69), which is active in the ethylene oligomerization.

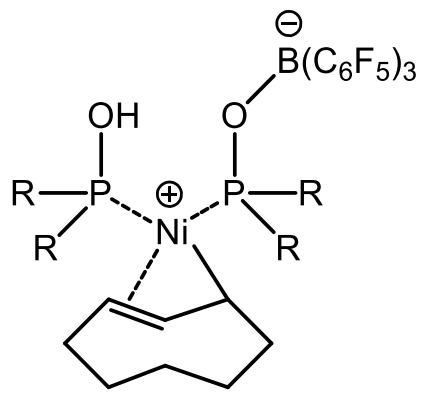

Figure 69. Activated nickel complex with secondary phosphine oxide ligands.

The determining effect of the electron-withdrawing substituents at phosphorus atoms on oligomerization activity of complex $\mathbf{9 3}$ is confirmed by the fact that complexes with benzyl, methoxyphenyl and hexyl substituents are much less active in ethylene oligomerization, compared to the more active complex with trifluoromethylphenyl substituents. An increase in steric hindrance at phosphorus atoms by the introduction of Me substituent at the ortho position of the phenyl ring leads to a drastic reduction of the butenes yield from $56 \%$ to $15 \%$ along with an increased $\mathrm{C}_{8+}$-oligomers content from $19 \%$ to $79 \%$ in the reaction products [123].

Lutz and co-workers proposed $\mathrm{Ni}^{\mathrm{iI}}$ complexes with distally diphosphinated calix[4]arenes as ethylene oligomerization pre-catalysts (94, Figure 70) [124].

Compared to $94 \mathrm{a}$, the complex $94 \mathrm{~b}$ exhibits higher activity in ethylene dimerization. Better catalytic performance of $\mathbf{9 4 \mathbf { b }}$ is explained by steric reasons: MAO possibly interacts with the calixarene-bonded bromides of 94a, forming very bulky substituents at calixarene which cause steric hindrances near the metal center, and thus reduces its activity. It was suggested that during the oligomerization process a permanent and fast fanning motion of $\mathrm{P}-\mathrm{Ni}-\mathrm{P}$ plane from one side of the complex to the other is observed. Such motion of the P-Ni-P plane results in a permanent variation of the ligand "bite angle". Expanding of the ligand "bite angle" possibly lowers the activation barrier of the reductive elimination step in the ethylene dimerization process [124]. 


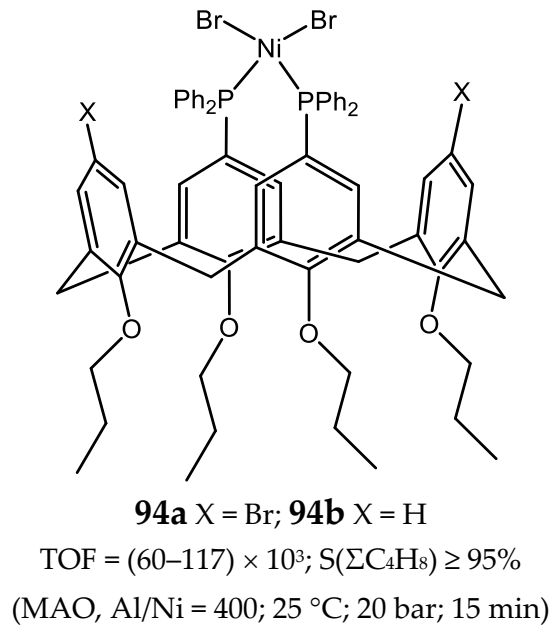

Figure 70. $\mathrm{Ni}^{\mathrm{II}}$ complexes ligated by diphosphinated calix[4]arenes.

\section{Nickel Complexes with N-Heterocyclic Carbene Ligands}

Owing to the strong binding to metals and, therefore, forming more stable complexes, compared to phosphine analogs, N-heterocyclic carbenes (NHC) (Figure 71) emerged as promising ligands for nickel-based olefin oligomerization/polymerization pre-catalysts [125-128].<smiles>[R]N1[C]=CN([R])C1</smiles>

Figure 71. N-heterocyclic carbene.

At the same time, NHC ligated nickel complexes with alkyl, aryl, and acyl substituents at the nitrogen atoms possess relatively low activity in ethylene oligomerization. For example, salicylaldiminato $\mathrm{Ni}$ (II) complex bearing N-heterocyclic carbene ligand (95, Figure 72) exhibits the activity of $8 \times 10^{3} \mathrm{~h}^{-1}$ in the ethylene dimerization process $\left(\mathrm{MMAO}, \mathrm{Al} / \mathrm{Ni}=500 ; 60{ }^{\circ} \mathrm{C} ; 7 \mathrm{bar} ; 60 \mathrm{~min}\right)$ [129].<smiles></smiles>

95

Figure 72. Salicylaldiminato Ni(II) complex with N-heterocyclic carbene.

It was assumed that such low activity is caused by the active site decomposition according to the reductive elimination mechanism (Figure 73) [126,130]. 


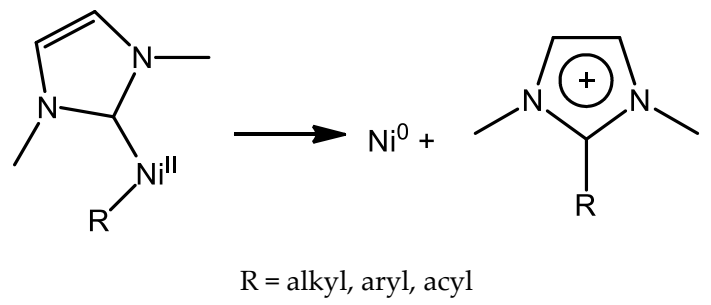

Figure 73. N-heterocyclic carbene (NHC) nickel complex decomposition by the reductive elimination.

In this respect, Braunstein and co-workers developed new NHC ligands N-substituted by ether or thioether groups (96, Figure 74), which could reversibly coordinate to nickel atoms and thus, increase the stability of active sites against decomposition [131].<smiles></smiles>

96

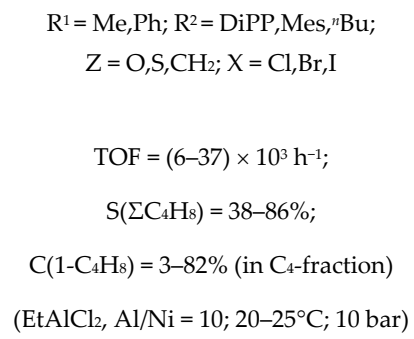

Figure 74. $\mathrm{Ni}^{\mathrm{II}}$ complexes with $\mathrm{NHC}$ ligands.

According to the catalytic tests, the introduction of the ether group to the nitrogen atom doesn't affect positively the oligomerization activity of complex $\mathbf{9 6}$. The activity of the complex containing ether-functionalized NHC ligand $\left(\mathrm{R}^{1}=\mathrm{DiPP}, \mathrm{R}^{2}=\mathrm{Me}, \mathrm{Z}=\mathrm{O}, \mathrm{X}=\mathrm{Br}\right)$ is close to that of alkyl functionalized NHC complex with the same length of alkyl chain $\left(\mathrm{R}^{1}=\mathrm{DiPP}, \mathrm{R}^{2}=\mathrm{Me}, \mathrm{Z}=\mathrm{CH}_{2}\right.$, $\mathrm{X}=\mathrm{Br}$ ) $-27 \times 10^{3}$ and $28 \times 10^{3} \mathrm{~h}^{-1}$, respectively. Moreover, it was observed that the decrease in steric hindrance on the N-substituent-in the transition from DiPP to ${ }^{n} \mathrm{Bu}$-leads to increased activity of the dichlorido- and dibromido-complexes. However, in the case of the diiodido-complexes, the opposite effect is observed. A decreased activity of the complex with the OPh substituent compared to that with the OMe moiety was also reported, which could be attributed to the increased steric bulk of OPh-functionalized ligand [131].

With an increase in the length of the alkyl bridge between nitrogen and oxygen atoms from two to three (97, Figure $75 \mathrm{a})$ the activity decreases from $10 \times 10^{3}$ to $7 \times 10^{3} \mathrm{~h}^{-1}$ [132].<smiles></smiles>

97

$\mathrm{n}=1: \mathrm{TOF}=10 \times 10^{3} \mathrm{~h}^{-1} ; \mathrm{S}\left(\Sigma \mathrm{C}_{4} \mathrm{H}_{8}\right)=64 \%$ $\mathrm{n}=2: \mathrm{TOF}=7 \times 10^{3} \mathrm{~h}^{-1} ; \mathrm{S}\left(\Sigma \mathrm{C}_{4} \mathrm{H}_{8}\right)=73 \%$

(a)<smiles>CN1CN(c2nccn2-c2ccccc2)C(Br)(Br)N1C</smiles>

98

$$
\begin{aligned}
& \mathrm{n}=2: \mathrm{TOF}=33 \times 10^{3} \mathrm{~h}^{-1} ; \mathrm{S}\left(\Sigma \mathrm{C}_{4} \mathrm{H}_{8}\right)=71 \% \\
& \mathrm{n}=3: \mathrm{TOF}=28 \times 10^{3} \mathrm{~h}^{-1} ; \mathrm{S}\left(\Sigma \mathrm{C}_{4} \mathrm{H}_{8}\right)=74 \%
\end{aligned}
$$

(b)

$\left(\mathrm{EtAlCl}_{2}, \mathrm{Al} / \mathrm{Ni}=10 ; 30-35^{\circ} \mathrm{C} ; 10\right.$ bar)

Figure 75. $\mathrm{Ni}^{\mathrm{II}}$ complexes bearing $\mathrm{O}-(\mathbf{a})$ and $\mathrm{N}$-functionalized (b) NHC-ligands. 
Replacement of the ether group by amine group (98, Figure 75b) leads to ca. 4-fold increase in oligomerization activity, which is due to the stabilization of the active sites by additional coordination of amine to Ni-center [132].

\section{Bi- and Multinuclear Nickel Complexes}

Braunstein and co-workers proposed binuclear nickel complexes with bidentate oxazoline alcohol and pyridine alcohol N,O-ligands as pre-catalysts for ethylene oligomerization (99-102, Figure 76) [133,134].

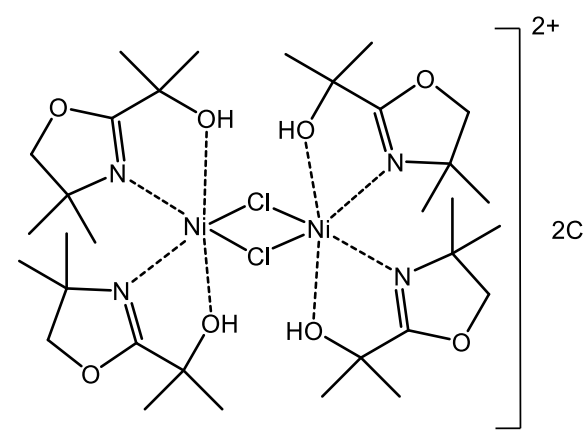

99

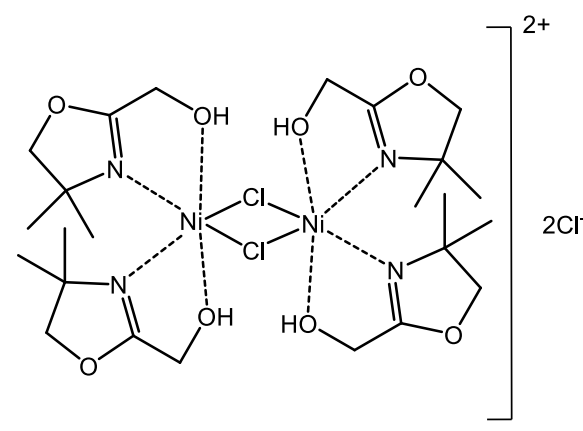

101

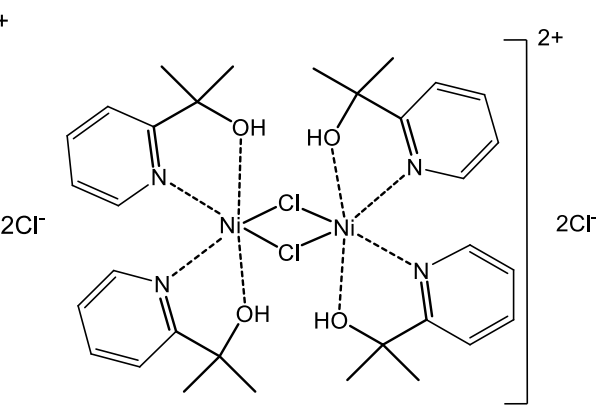

100

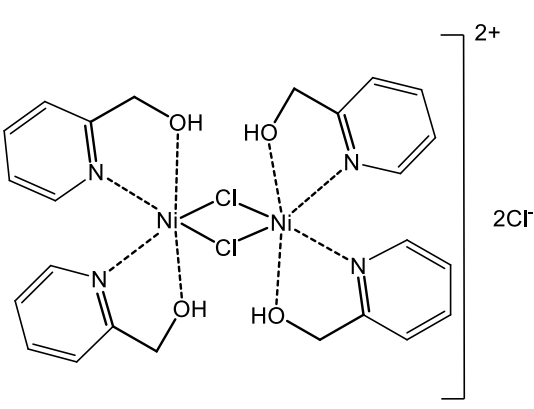

102

TOF $=(5-37) \times 10^{3} \mathrm{~h}^{-1} ; \mathrm{S}\left(\Sigma \mathrm{C}_{4} \mathrm{H}_{8}\right)=58-80 \% ; \mathrm{C}\left(1-\mathrm{C}_{4} \mathrm{H}_{8}\right)=34-88 \%$ (in $\mathrm{C}_{4}$-fraction)

(MAO, $\mathrm{Al} / \mathrm{Ni}=200 ; 25-30^{\circ} \mathrm{C} ; 10$ bar)

Figure 76. Binuclear $\mathrm{Ni}^{\mathrm{II}}$ complexes with oxazoline alcohol and pyridine alcohol N,O-ligands.

These complexes have octahedral coordination geometry around the nickel center. In the case of complexes with ligands bearing gem-dimethyl substituents at $\alpha$ position to OH-group, the oxazoline alcohol containing complex 99 exhibits higher activity compared to the pyridine alcohol complex 100 with a more basic nitrogen atom $\left(16 \times 10^{3}\right.$ vs. $5 \times 10^{3} \mathrm{~h}^{-1}$, oligomerization in toluene). Both compounds have close selectivity for butenes $-88 \%$ and $87 \%$, respectively. In the case of unsubstituted complexes 101 and 102, and when using a more polar solvent-a mixture of $10 \mathrm{~mL}$ of chlorobenzene and $2 \mathrm{~mL}$ of toluene-the same activity is observed for the oxazoline and pyridine systems- $(36-37) \times 10^{3} \mathrm{~h}^{-1}[134]$.

Swarts and Mapolie investigated binuclear chloro-bridged nickel(II) $\mathrm{N}$-alkyl dipyridylaldiminato complexes (103a-e, Figure 77) [135].

The authors report that the effect of the $\mathrm{N}$-alkyl substituents on catalytic activity is insignificant. At the same time, the introduction of Me groups at the ortho position of the pyridyl fragment (103e) leads to a decrease in activity from $21 \times 10^{3}$ to $18 \times 10^{3} \mathrm{~h}^{-1}$ due to increased steric hindrances. For complexes 103a-d the major butene isomer formed during oligomerization is 2-butene (64-78\%). In the case of complex 103e, the main product is 1-butene (98\%). The increased selectivity for 1-butene is attributed to the presence of $o$-Me groups which retard the 1-butene isomerization by increasing steric pressure within the nickel coordination sphere. As a result, the olefin orients in the plane of the metal center 
before the elimination, which leads to destabilization of active center and decrease in the propensity toward isomerization [135].

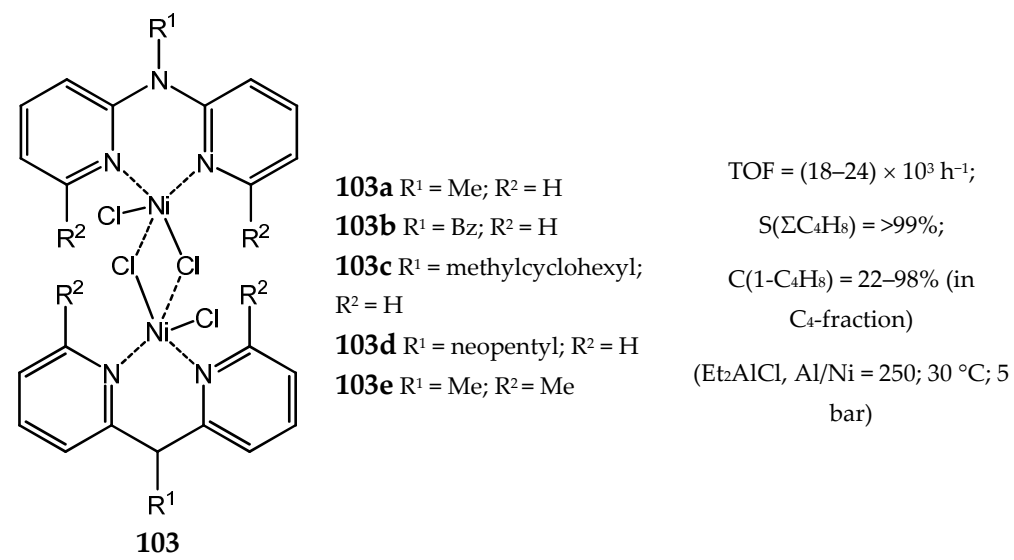

Figure 77. Binuclear nickel(II) N-alkyl dipyridylaldiminato complexes.

Hey-Hawkins et al. developed a method for the synthesis of novel nickel bisamido complex 104 (Figure 78) and investigated the catalytic activity of this compound in ethylene oligomerization [136].

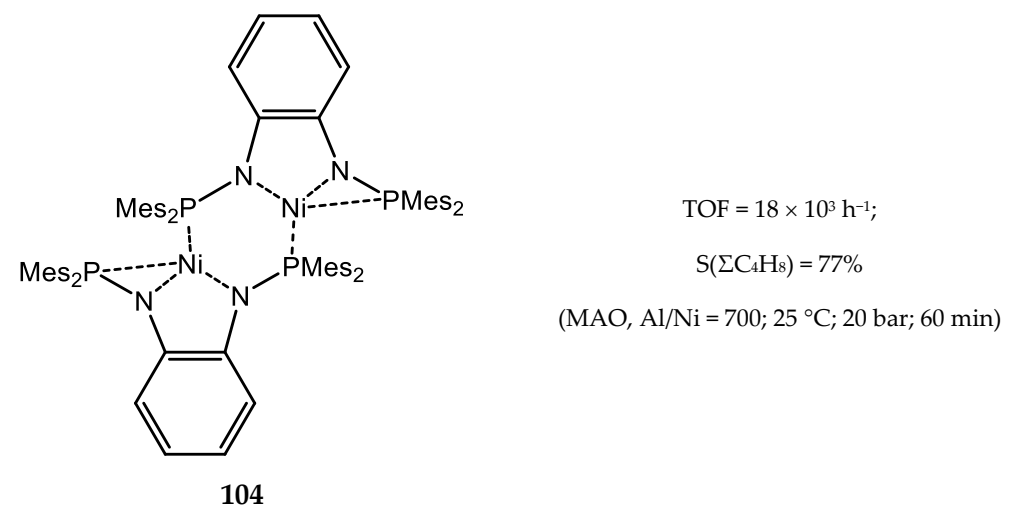

Figure 78. Nickel bisamido complex $\left[\mathrm{Ni}\left\{1-\mathrm{N}\left(\mathrm{PMes}_{2}\right)-2-\mathrm{N}\left(\mu-\mathrm{PMes}_{2}\right) \mathrm{C}_{6} \mathrm{H}_{4}-\mathrm{k}^{3} \mathrm{~N}, \mathrm{~N}^{\prime}, \mathrm{P}-\mathrm{k}^{1} \mathrm{P}^{\prime}\right\}\right]_{2}$.

The activated complex 104 exhibits the highest activity in dichloromethane (TOF $\left.=79 \times 10^{3} \mathrm{~h}^{-1}\right)$ and produces a mixture of ethylene dimers (54\%) and trimers (46\%) [136].

Sun and co-workers synthesized new bi- and tetranuclear $\mathrm{Ni}^{\mathrm{II}}$ complexes. In [137] the preparation of unsymmetric binuclear $\mathrm{Ni}^{\mathrm{II}}$ complexes ligated by 2-methyl-2,4-bis(6-iminopyridin-2-yl)- $1 \mathrm{H}-1,5-$ benzodiazepines was reported (105, Figure 79).

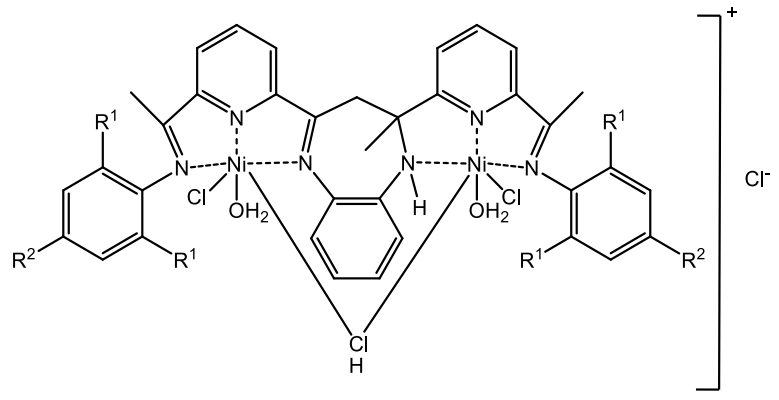

$\mathrm{R}^{1}=\mathrm{Me}, \mathrm{Et},{ }^{\mathrm{P} r} ; \mathrm{R}^{2}=\mathrm{H}, \mathrm{Me}$

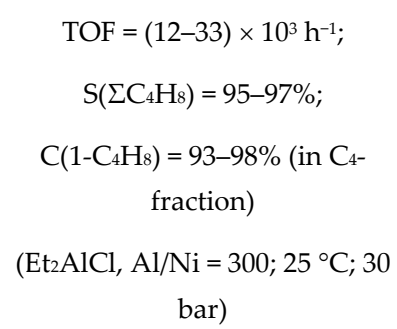

105

Figure 79. Binuclear $\mathrm{Ni}^{\mathrm{II}}$ complexes with 2-methyl-2,4-bis(6-iminopyridin-2-yl)-1H-1,5-benzodiazepines. 
According to X-ray diffraction data, complex $\mathbf{1 0 5}$ is not symmetrical due to the action of the diazepine ring and the binding chloride. Different substituents at the imino-N-aryl ring influence the catalytic properties of the obtained complexes. It was found that sterically bulkier 2,6-dialkyl substituents reduce the catalytic activity and selectivity for 1-butene. The highest activity (TOF $=33 \times 10^{3} \mathrm{~h}^{-1}$ ) was observed for the complex with Et substituents at ortho positions of the aryl ring [137].

The synthesis of tetranuclear $\mathrm{Ni}^{\mathrm{II}}$ complexes with $\mathrm{N}$-(pyridin-2-yl)picolinamide derivatives (106, Figure 80) was reported in [138]. The tetranickel cluster, in this case, can be described as a dimer of two binuclear complexes bridged via $\mu_{3}-\mathrm{OMe}$ and $\mu_{2}$ - $\mathrm{Br}$ fragments.

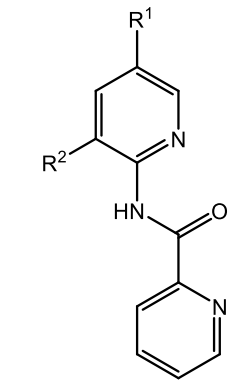

$\mathrm{R}^{1}=\mathrm{H}, \mathrm{Br}, \mathrm{CF}_{3} ; \mathrm{R}^{2}=\mathrm{H}, \mathrm{Br}$,

$\mathrm{Cl}$

(a)

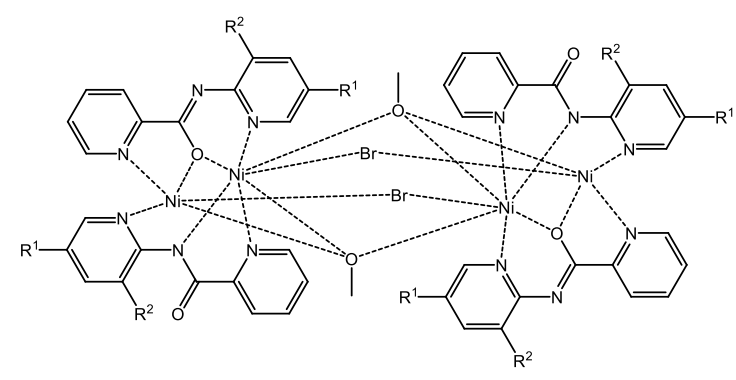

106

TOF $=(58-96) \times 10^{3} \mathrm{~h}^{-1} ;$

$\mathrm{S}\left(\Sigma \mathrm{C}_{4} \mathrm{H}_{8}\right)=96-97 \% ; \mathrm{S}\left(1-\mathrm{C}_{4} \mathrm{H}_{8}\right)=93-96 \%$

(MAO, $\mathrm{Al} / \mathrm{Ni}=1000 ; 20^{\circ} \mathrm{C} ; 30$ bar)

(b)

Figure 80. N-(Pyridin-2-yl)picolinamide ligands (a) and tetranuclear $\mathrm{Ni}^{\mathrm{II}}$ complexes (b).

The authors reported that the introduction of the electron-withdrawing substituents such as bromide, chloride and $\mathrm{CF}_{3}$ at the $\mathrm{N}$-imino pyridine ring lowers the oligomerization activity of complex 106 from $96 \times 10^{3}$ to $(58-70) \times 10^{3} \mathrm{~h}^{-1}$. Moreover, the elevation of oligomerization temperature from 20 to $60^{\circ} \mathrm{C}$ also decreases the activity of the catalytic system (from $96 \times 10^{3}$ to $27 \times 10^{3} \mathrm{~h}^{-1}$ ), due to the decomposition of the active species and the lower solubility of ethylene in toluene at higher temperatures [138].

In [139] nickel(II) complexes bearing hyperbranched iminopyridyl ligands were presented (107, Figure 81).

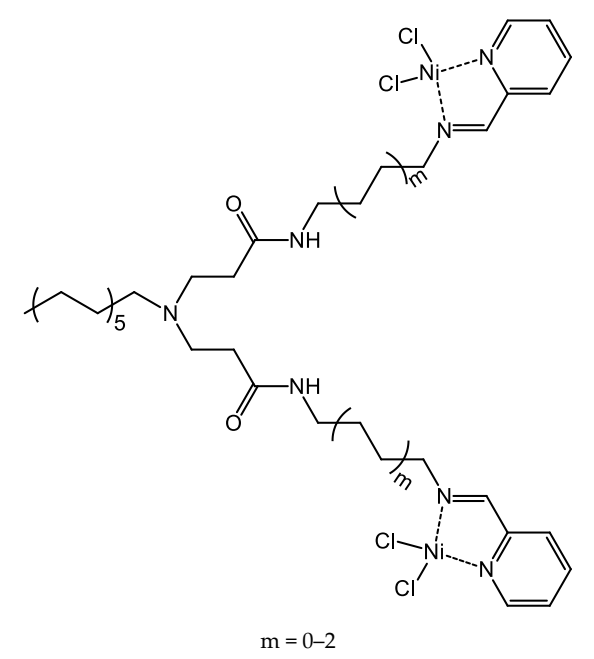

107

$\mathrm{TOF}=(10-22) \times 10^{3} \mathrm{~h}^{-1}, \mathrm{~S}\left(\Sigma \mathrm{C}_{4} \mathrm{H}_{8}\right)=47-55 \%$;

(MAO, $\mathrm{Al} / \mathrm{Ni}=500 ; 25^{\circ} \mathrm{C} ; 5$ bar)

Figure 81. Hyperbranched iminopyridyl $\mathrm{Ni}^{\mathrm{II}}$ complexes. 
An increase in the length of the alkyl chain by $2-4$ carbon atoms leads to a decrease in activity from $22 \times 10^{3}$ to $(10-17) \times 10^{3} \mathrm{~h}^{-1}$ [139].

Binuclear nickel(II) complexes bearing pyridine-imine ligands (108, Figure 82) were developed [140,141]. These complexes, activated by $\mathrm{Et}_{2} \mathrm{AlCl}$ or $\mathrm{Et}_{3} \mathrm{Al}_{2} \mathrm{Cl}_{3}$, oligomerize ethylene predominantly to 1-butene.

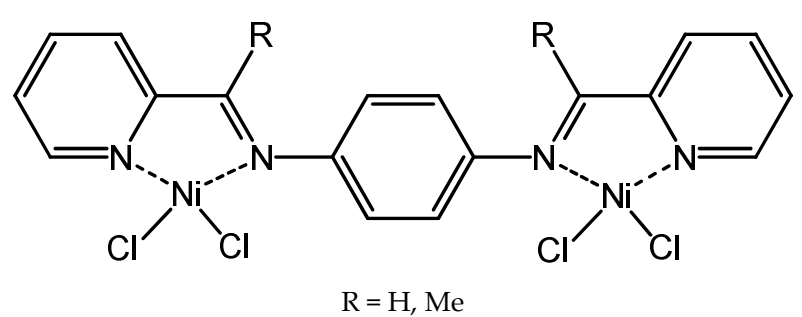

108
$\mathrm{TOF}=(6-85) \times 10^{3} \mathrm{~h}^{-1} ;$
$\mathrm{S}\left(1-\mathrm{C}_{4} \mathrm{H}_{8}\right)=>90 \%$
$\left(\mathrm{Et}_{2} \mathrm{AlCl}\right.$ or $\mathrm{Et}_{3} \mathrm{Al}_{2} \mathrm{Cl}_{3}, \mathrm{Al} / \mathrm{Ni}=500 ;$

$50{ }^{\circ} \mathrm{C} ; 20$ bar)

Figure 82. Binuclear nickel(II) complexes bearing para-phenylene-linked pyridine-imine ligand.

\section{Effect of the co-Catalyst on the Catalytic Properties}

Most of the presented catalytic systems are based on the cationic nickel complexes. Therefore, it is worth mentioning that the type of co-catalyst has determining influence on the catalytic properties. For example in the most cases considered (complexes 4, 5, 8-10, 13-15, 18-20, 24, 25, 30, 34, 35, 40, $43-45,47,52,53,55,59,65,66,69,73-76,78-82,99-103$ and 105) the change of methylaluminoxane to $\mathrm{Et}_{2} \mathrm{AlCl}, \mathrm{EtAlCl}_{2}$ or $\mathrm{Et}_{3} \mathrm{Al}_{2} \mathrm{Cl}_{3}$ of lower amount (2-20 times lower, in terms of $\mathrm{Al}$ ) leads to a significant (from 2- to 70-fold) increase in activity. This may be caused not only by an increase in the Lewis acidity, which favors halide abstraction, but also by the greater stabilization of the active sites and the transition states of the catalytic cycle. This was confirmed by the recent results of spectroscopic and DFT studies of the ethylene polymerization on methylaluminoxane activated zirconocenes [142-144]. According to the mechanism proposed, for the activation of complex the $\mathrm{AlMe}_{2}{ }^{+}$-species (from the terminal aluminum centers of methylaluminoxane) are responsible. These species replace halides with methyl groups and then stabilize the active sites (109, Figure 83).

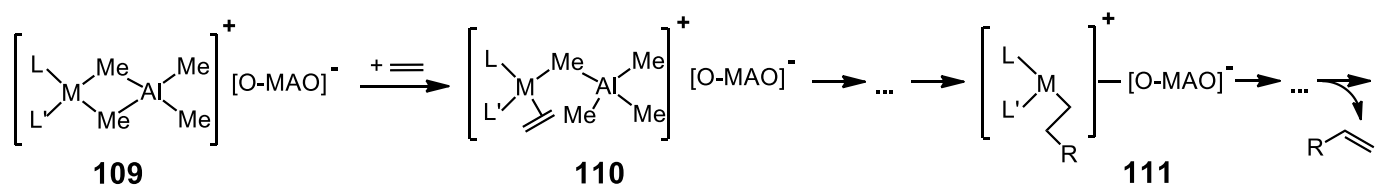

(a)

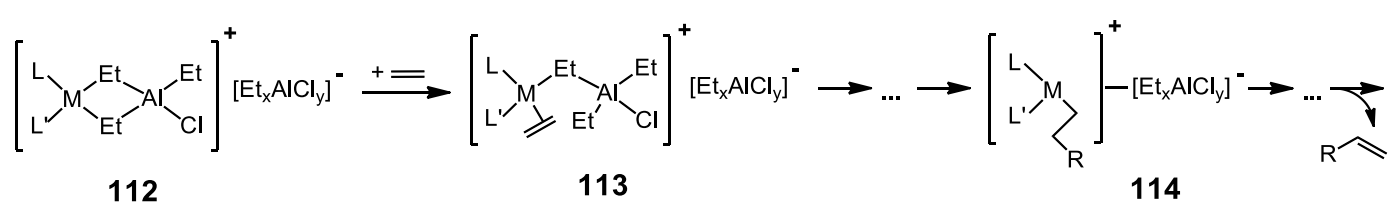

(b)

Figure 83. Selected steps of ethylene oligomerization/polymerization catalytic cycle with different co-catalysts-methylaluminoxane (a) and ethylaluminum chloride (b).

Taking into account this mechanism, higher oligomerization activity in the case of ethylaluminum chloride co-catalysts may be due to the few reasons. Firstly, presence of the electron-withdrawing chloride can increase the electrophilicity of the metal center, which is favorable for the ethylene coordination (112 vs. 109, Figure 83). Secondly, chloride ion can facilitate the metall-alkyl bond cleavage (113 vs. 110, Figure 83), which is required for ethylene coordination to the metal center. Thirdly, reversible interaction between metal center and the anion, which is required for further $\beta$-agostic interaction and elimination of alpha-olefin, will be greater in the case of ethylaluminum 
chlorides because of higher electronegativity of anion caused by the presence of chlorides compared to oxygen sites in methylaluminoxane (114 vs. 111, Figure 83). In the case of the latter co-catalyst the metal-anion interaction can be complicated due to the bulkiness of anion, which is the part of the methylaluminoxane three-dimensional macromolecule $[31,142,143]$.

However, for some complexes (6 [42], 36 [71], 37 [75]) methylaluminoxane provides higher oligomerization activity compared to ethylaluminum chlorides. In the case of complexes 6 and 49 the change of $\mathrm{MAO}$ to $\mathrm{Et}_{3} \mathrm{Al}_{2} \mathrm{Cl}_{3}$ and $\mathrm{EtAlCl}_{2}$, respectively, leads to the Friedel-Crafts toluene alkylation instead of ethylene oligomerization [42,84].

Thus, the type of co-catalyst has a decisive influence on the catalytic properties, and it must be selected individually for each system to provide optimal active site stabilization and cation-anion interaction.

\section{Conclusions}

The demand of the global polymer market for short-chain linear alpha-olefins in the last two decades has led to intensive research in the field of metal complexes used in the processes of selective homogeneous ethylene oligomerization. In this work, we reviewed modern Ni-based catalytic systems of ethylene oligomerization, predominantly dimerization. We mainly focused our attention on the influence of molecular structure, electronic and coordination states of the nickel complexes on their catalytic activity.

Catalytic systems based on nickel complexes are promising alternatives to the titanium alcoholate/triethylaluminum composition which is used in the only industrial process of ethylene dimerization to 1-butene-the "AlphaButol" (Axens-SABIC) $[5,7,145,146]$. Advantages of the majority of considered nickel-based systems over the latter are higher activity, the absence of polymers in products, as well as lower energy costs of dimerization process due to the use of lower temperature $\left(25-30{ }^{\circ} \mathrm{C}\right.$ vs. $\left.50-60^{\circ} \mathrm{C}\right)$ and ethylene pressure (10-20 bar vs. 30 bar) [146].

As follows from the review, the most elaborated nickel pre-catalysts for ethylene dimerization are single-center asymmetric complexes of $\mathrm{Ni}^{\mathrm{II}}$ with tridentate ligands containing two or three nitrogen atoms in the conjugated system. Among these systems, there are certain examples which combine outstanding activity and high selectivity towards butenes/1-butene (for example, dichloride $\mathrm{Ni}^{\mathrm{II}}$ complex bearing 2-(benzimidazol-2-yl)-1,10-phenanthroline ligand, with TOF $=453 \times 10^{3} \mathrm{~h}^{-1}$, $\left.\mathrm{S}\left(\Sigma \mathrm{C}_{4} \mathrm{H}_{8}\right)=90 \%, \mathrm{~S}\left(1-\mathrm{C}_{4} \mathrm{H}_{8}\right)=73 \%\right)[38]$.

Taking into account, that the most effective systems are based on cationic nickel complexes, the catalytic properties are largely determined by the co-catalyst used. At the same time, a significant amount of the expensive organoaluminum co-catalyst is used to activate the reviewed pre-catalysts. The typical $\mathrm{Al} / \mathrm{Ni}$ ratio is $200-1000$. Therefore, the reduction of the $\mathrm{Al} / \mathrm{Ni}$ ratio without negative impact on the catalytic activity and selectivity, as well as search and development of alternative activators and/or new methods of metal complexes activation, including methods of in situ generation of catalytically active species are important areas of the further research in the field of homogenous ethylene oligomerization/dimerization.

It was shown that the chemical nature of the solvent and the introduction of an auxiliary ligand have a significant effect on the catalytic properties and stability of the active species. Thus, the optimization of the oligomerization process conditions is crucial for the development of effective catalytic systems.

Author Contributions: Conceptualization and methodology of this review, collecting of the data and original draft preparation-G.E.B., A.M.K., A.V.S. and D.G.Y. Writing-review and editing-G.E.B., A.M.K. and D.G.Y. All authors have read and agreed to the published version of the manuscript.

Funding: This work was funded by the Russian Government Program of Competitive Growth of Kazan Federal University (Reg. Nr. AAAA-A19-119053190012-8) and the Government assignment for FRC Kazan Scientific Center of RAS (Reg. Nr. AAAA-A18-118041760011-2).

Acknowledgments: The authors are thankful to the Russian Government Program of Competitive Growth of Kazan Federal University for financial support of the collecting data for organic compounds and performing of the catalytic experiments in KFU. The Government assignment for FRC Kazan Scientific Center of RAS for supporting the research activity dealing with phosphorus containing ligands is also gratefully acknowledged.

Conflicts of Interest: The authors declare no conflict of interest. 


\section{Appendix A}

It is necessary to make notes regarding the presentation in the review of the conditions and results of catalytic tests:

(1) in most of the cases discussed above:

- ethylene oligomerization cycle was carried out for 20-35 min, otherwise it is indicated;

-in catalytic tests, toluene was used as a solvent, otherwise it is indicated;

- selectivities for butenes, 1-butene, and hexenes were rounded to the nearest integer.

(2) In the works, where the activity is expressed in $\left[\mathrm{g} \times \mathrm{mol}_{\mathrm{Ni}}{ }^{-1} \times \mathrm{h}^{-1}\right]$, to convert to the dimension of TOF $\left[\mathrm{mol}_{\mathrm{C} 2 \mathrm{H} 4} \times \mathrm{mol}_{\mathrm{Ni}}^{-1} \times \mathrm{h}^{-1}\right]=\left[\mathrm{h}^{-1}\right]$, the value was divided by the molar weight of ethylene $\left(28 \mathrm{~g} \times \mathrm{mol}^{-1}\right)$, using Equation (A1):

$$
[\mathrm{TOF}]=\frac{\text { Activity }\left[\mathrm{g} \times \mathrm{mol}_{\mathrm{Ni}}^{-1} \times \mathrm{h}^{-1}\right]}{\operatorname{Mr}_{\mathrm{C} 2 \mathrm{H} 4}\left[\mathrm{~g} \times \mathrm{mol}^{-1}\right]}=\left[\mathrm{h}^{-1}\right]
$$

(3) To convert activity, which expressed in $\left[\mathrm{g} \times \mathrm{mol}_{\mathrm{Ni}}{ }^{-1} \times \mathrm{h}^{-1} \times \mathrm{bar}^{-1}\right]$, to the dimension of TOF $\left[\mathrm{mol}_{\mathrm{C} 2 \mathrm{H} 4} \times \mathrm{mol}_{\mathrm{Ni}^{-1}}{ }^{-1} \mathrm{~h}^{-1}\right]=\left[\mathrm{h}^{-1}\right]$, the value was divided by the molar weight of ethylene $\left(28 \mathrm{~g} \times \mathrm{mol}^{-1}\right)$ and multiplied by the ethylene pressure of the catalytic test, using Equation (A2):

$$
[\mathrm{TOF}]=\frac{\text { Activity }\left[\mathrm{g} \times \mathrm{mol}_{\mathrm{Ni}}^{-1} \times \mathrm{bar}^{-1} \times \mathrm{h}^{-1}\right] \times \mathrm{P}[\mathrm{bar}]}{\mathrm{Mr}_{\mathrm{C} 2 \mathrm{H} 4}\left[\mathrm{~g} \times \mathrm{mol}^{-1}\right]}=\left[\mathrm{h}^{-1}\right]
$$

\section{References}

1. Camara Greiner, E.O.; Inoguchi, Y. Chemical Economics Handbook. Linear Alpha-Olefins (681.5030); SRI Consulting: Menlo Park, CA, USA, 2010; pp. 1-78.

2. Fischer, K.; Jonas, K.; Misbach, P.; Stabba, R.; Wilke, G. The “Nickel Effect”. Angew. Chem. Int. Ed. Engl. 1973, 12, 943-953. [CrossRef]

3. Keim, W. Nickel: An element with wide application in industrial homogeneous ctalysis. Angew. Chem. Int. Ed. Engl. 1990, 29, 235-244. [CrossRef]

4. Keim, W. Oligomerization of ethylene to $\alpha$-olefins: Discovery and development of the Shell Higher Olefin Process (SHOP). Angew Chem. Int. Ed. 2013, 52, 12492-12496. [CrossRef]

5. Breuil, P.-A.R.; Magna, L.; Olivier-Bourbigou, H. Role of homogeneous catalysis in oligomerization of olefins: Focus on selected examples based on group 4 to group 10 transition metal complexes. Catal. Lett. 2015, 145, 173-192. [CrossRef]

6. Belov, G.P.; Matkovsky, P.E. Processes for the production of higher linear $\alpha$-olefins. Pet. Chem. 2010, 50, 283-289. [CrossRef]

7. Forestière, A.; Olivier-Bourbigou, H.; Saussine, L. Oligomerization of monoolefins by homogeneous catalysts. Oil Gas. Sci. Technol. Rev. IFP 2009, 64, 649-667. [CrossRef]

8. Nomura, K.; Itagaki, M.; Ishino, M.; Yamamoto, M.; Suzukamo, G. Efficient dimerization of propylene affording 2,3-dimethylbutenes by fluorinated alcohol modified nickel-phosphine catalyst system containing strong sulfonic acid and/or dialkyl sulfates. Catal. Lett. 1997, 47, 47-49. [CrossRef]

9. Volkova, A.V. The Market for Large-tonnage Polymers. Part I. Polyethylene; HSE University: St. Petersburg, Russia, 2016.

10. Agapie, T. Selective ethylene oligomerization: Recent advances in chromium catalysis and mechanistic investigations. Coord. Chem. Rev. 2011, 255, 861-880. [CrossRef]

11. Bryliakov, K.P.; Antonov, A.A. Recent progress of transition metal based catalysts for the selective dimerization of ethylene. J. Organomet. Chem. 2018, 867, 55-61. [CrossRef]

12. Keim, W. Nickel Hydrides: Catalysis in oligomerization and polymerization reactions of olefins. Ann. N.Y. Acad. Sci. 1983, 415, 191-200. [CrossRef]

13. Cossee, P. Ziegler-Natta catalysis I. Mechanism of polymerization of $\alpha$-olefins with Ziegler-Natta catalysts. J. Catal. 1964, 3, 80-88. [CrossRef] 
14. Arlman, E.; Cossee, P. Ziegler-Natta catalysis III. Stereospecific polymerization of propene with the catalyst system $\mathrm{TiCl}_{3}-\mathrm{AlEt}_{3}$. J. Catal. 1964, 3, 99-104. [CrossRef]

15. Skupinska, J. Oligomerization of $\alpha$-olefins to higher oligomers. Chem. Rev. 1991, 91, 613-648. [CrossRef]

16. Forget, S.; Olivier-Bourbigou, H.; Delcroix, D. Homogeneous and heterogeneous nickel-catalyzed olefin oligomerization: Experimental investigation for a common mechanistic proposition and catalyst optimization. ChemCatChem 2017, 9, 2408-2417. [CrossRef]

17. Johnson, L.K.; Killian, C.M.; Brookhart, M. New Pd(II)- and Ni(II)-based catalysts for polymerization of ethylene and $\alpha$-olefins. J. Am. Chem. Soc. 1995, 117, 6414-6415. [CrossRef]

18. Britovsek, G.J.; Baugh, S.P.; Hoarau, O.; Gibson, V.C.; Wass, D.F.; White, A.J.; Williams, D.J. The role of bulky substituents in the polymerization of ethylene using late transition metal catalysts: A comparative study of nickel and iron catalyst systems. Inorg. Chim. Acta 2003, 345, 279-291. [CrossRef]

19. Wang, Z.; Solan, G.A.; Zhang, W.; Sun, W.-H. Carbocyclic-fused N,N,N-pincer ligands as ring-strain adjustable supports for iron and cobalt catalysts in ethylene oligo-/polymerization. Coord. Chem. Rev. 2018, 363, 92-108. [CrossRef]

20. Bryliakov, K.P.; Talsi, E.P. Frontiers of mechanistic studies of coordination polymerization and oligomerization of $\alpha$-olefins. Coord. Chem. Rev. 2012, 256, 2994-3007. [CrossRef]

21. Budagumpi, S.; Keri, R.S.; Biffis, A.; Patil, S.A. Olefin poly/oligomerizations by metal precatalysts bearingnon-heterocyclic N-donor ligands. Appl. Catal. A 2017, 535, 32-60. [CrossRef]

22. Bianchini, C.; Giambastiani, G.; Mantovani, G.; Meli, A.; Mimeau, D. Oligomerisation of ethylene to linear $\alpha$-olefins by tetrahedral cobalt(II) precursors stabilised by benzo[b]thiophen-2-yl-substituted (imino)pyridine ligands. J. Organomet. Chem. 2004, 689, 1356-1361. [CrossRef]

23. Bianchini, C.; Giambastiani, G.; Guerrero Rios, I.; Mantovani, G.; Meli, A.; Segarra, A.M. Ethylene oligomerization, homopolymerization and copolymerization by iron and cobalt catalysts with 2,6-(bis-organylimino)pyridyl ligands. Coord. Chem. Rev. 2006, 250, 1391-1418. [CrossRef]

24. Bianchini, C.; Gatteschi, D.; Giambastiani, G.; Guerrero Rios, I.; Ienco, A.; Laschi, F.; Mealli, C.; Meli, A.; Sorace, L.; Toti, A.; et al. Electronic influence of the thienyl sulfur atom on the oligomerization of ethylene by cobalt(II) 6-(thienyl)-2-(imino)pyridine catalysis. Organometallics 2007, 26, 726-739. [CrossRef]

25. Antonov, A.A.; Semikolenova, N.V.; Talsi, E.P.; Matsko, M.A.; Zakharov, V.A.; Bryliakov, K.P. 2-Iminopyridine nickel(II) complexes bearing electron-withdrawing groups in the ligand core: Synthesis, characterization, ethylene oligo- and polymerization behaviour. J. Organomet. Chem. 2016, 822, 241-249. [CrossRef]

26. Yakhvarov, D.G.; Tazeev, D.I.; Sinyashin, O.G.; Giambastiani, G.; Bianchini, C.; Segarra, A.M.; Lönnecke, P.; Hey-Hawkins, E. Electrochemical synthesis of the $\sigma$-aryl complex $[\mathrm{NiBr}(\mathrm{Mes})(\mathrm{bpy})]$ and its use as catalyst precursor for the oligomerization of ethylene (Mes =2,4,6-trimethylphenyl, bpy =2,20-bipyridine). Polyhedron 2006, 25, 1607-1612. [CrossRef]

27. Yakhvarov, D.G.; Trofimova, E.A.; Rizvanov, I.K.; Fomina, O.S.; Sinyashin, O.G. Electrochemical synthesis and catalytic activity of organonickel sigma-complexes. Russ. J. Electrochem. 2011, 47, 1100-1110. [CrossRef]

28. Yakhvarov, D.G.; Khusnuriyalova, A.F.; Sinyashin, O.G. Electrochemical synthesis and properties of organonickel $\sigma$-complexes. Organometallics. 2014, 33, 4574-4589. [CrossRef]

29. Wang, Z.; Liu, Q.; Solan, G.A.; Sun, W.-H. Recent advances in Ni-mediated ethylene chain growth: $\mathrm{N}_{\text {imine }}$-donor ligand effects on catalytic activity, thermal stability and oligo-/polymer structure. Coord. Chem. Rev. 2017, 350, 68-83. [CrossRef]

30. Wang, S.; Sun, W.-H.; Redshaw, C. Recent progress on nickel-based systems for ethylene oligo-/polymerization catalysis. J. Organomet. Chem. 2014, 751, 717-741. [CrossRef]

31. Bianchini, C.; Giambastiani, G.; Luconi, L.; Meli, A. Olefin oligomerization, homopolymerization and copolymerization by late transition metals supported by (imino)pyridine ligands. Coord. Chem. Rev. 2010, 254, 431-455. [CrossRef]

32. Killian, C.M.; Johnson, L.K.; Brookhart, M. Preparation of linear $\alpha$-olefins using cationic nickel(II) $\alpha$-diimine catalysts. Organometallics 1997, 16, 2005-2007. [CrossRef]

33. Song, S.; Xiao, T.; Liang, T.; Wang, F.; Redshaw, C.; Sun, W.H. Synthesis, characterization and ethylene oligomerization behaviour of 8-(1-aryliminoethylidene)quinaldinylnickel dihalides. Catal. Sci. Technol. 2011,1, 69-75. [CrossRef] 
34. Sun, W.-H.; Wang, K.; Wedeking, K.; Zhang, D.; Zhang, S.; Cai, J.; Li, Y. Synthesis, characterization, and ethylene oligomerization of nickel complexes bearing $N$-((pyridin-2-yl)methylene)quinolin-8-amine derivatives. Organometallics 2007, 26, 4781-4790. [CrossRef]

35. Song, Y.; Zhang, S.; Deng, Y.; Jie, S.; Li, L.; Lu, X.; Sun, W.-H. 2,9-disubstituted 1,10-phenanthroline nickel complexes: Syntheses, characterization, and their ethylene oligomerization. Kinet. Catal. 2007, 48, 664-668. [CrossRef]

36. Gao, R.; Xiao, L.; Hao, X.; Sun, W.-H.; Wang, F. Synthesis of benzoxazolylpyridine nickel complexes and their efficient dimerization of ethylene to $\alpha$-butene. Dalton Trans. 2008, 5645-5651. [CrossRef] [PubMed]

37. Hao, P.; Zhang, S.; Sun, W.-H.; Shi, Q.; Adewuyi, S.; Lu, X.; Li, P. Synthesis, characterization and ethylene oligomerization studies of nickel complexes bearing 2-benzimidazolylpyridine derivatives. Organometallics 2007, 26, 2439-2446. [CrossRef]

38. Zhang, M.; Zhang, S.; Hao, P.; Jie, S.; Sun, W.-H.; Li, P.; Lu, X. Nickel complexes bearing 2-(benzimidazol-2-yl) -1,10-phenanthrolines: Synthesis, characterization and their catalytic behavior toward ethylene oligomerization. Eur. J. Inorg. Chem. 2007, 2007, 3816-3826. [CrossRef]

39. Wei, X.; Jiang, Y.; Cui, X.; Li, Y.; Wang, H.; Qi, X. 2-Benzoimidazol-8-alkylquinolinylnickel(II) complexes as efficient catalysts for ethylene oligomerization and vinyl polymerization of norbornene. J. Coord. Chem. 2015, 68, 3825-3838. [CrossRef]

40. Song, S.; Li, Y.; Redshaw, C.; Wang, F.; Sun, W.-H. 2-(1-Aryliminoethylidene)quinolylnickel(II) dibromides: Synthesis, characterization and ethylene dimerization capability. J. Organomet. Chem. 2011, 696, 3772-3778. [CrossRef]

41. Chai, W.; Yu, J.; Wang, L.; Hu, X.; Redshaw, C.; Sun, W.-H. Synthesis, characterization and ethylene oligomerization behavior of N-(2-alkyl-5,6,7-trihydroquinolin-8-ylidene)arylaminonickel(II) dichlorides. Inorg. Chim. Acta. 2012, 385, 21-26. [CrossRef]

42. Antonov, A.A.; Semikolenova, N.V.; Soshnikov, I.E.; Talsi, E.P.; Bryliakov, K.P. Selective ethylene dimerization into 2-butenes using homogeneous and supported nickel(II) 2-iminopyridine catalysts. Top. Catal. 2020, 63, 222-228. [CrossRef]

43. Hao, P.; Song, S.; Xiao, T.; Li, Y.; Redshaw, C.; Sun, W.-H. Highly active 8-benzoxazolyl- or 8-benzothiazolyl-2-alkylquinolinylnickel(II) complexes for ethylene dimerization and vinyl polymerization of norbornene. Polyhedron 2013, 52, 1138-1144. [CrossRef]

44. Xiao, L.; Jie, S.; Song, Y.; Cao, X.; Sun, W.-H. Transformation of 2-alkoxyimidate-1,10-phenanthroline metal $\left(\mathrm{Mn}^{2+}, \mathrm{Co}^{2+}\right.$ and $\left.\mathrm{Ni}^{2+}\right)$ chlorides from bis(2-cyano-1,10-phenanthroline) metal chlorides: Syntheses, characterizations and their catalytic behavior toward ethylene oligomerization. J. Organomet. Chem. 2008, 693, 3858-3866. [CrossRef]

45. Milani, J.L.S.; Casagrande, A.C.A.; Livotto, P.R.; Casagrande, O.L. Synthesis and characterization of ether-imine-furfural [ONO] nickel(II) complexes and their application in oligomerization of ethylene. Appl. Catal. A 2016, 523, 247-254. [CrossRef]

46. Fernando de Souza, R. XAS study of the nickel( $\alpha$-diimine) catalyst for olefin polymerization. J. Catal. 2003, 214, 165-168. [CrossRef]

47. Corker, J.M.; Evans, J. EXAFS studies of the activation of homogeneous nickel catalysts for propene dimerisation by aluminium reagents. J. Chem. Soc. Chem. Commun. 1991, 1104-1106. [CrossRef]

48. Cornils, B.; Herrmann, W.A.; Beller, M.; Paciello, R. Oligomerization, cyclooligomerization, dimerization. In Applied Homogeneous Catalysis with Organometallic Compounds: A Comprehensive Handbook in Four Volumes; Wiley-VCH Verlag GmbH \& Co. KGaA: Weinheim, Germany, 2018; pp. 307-409.

49. Milani, J.L.S. Chromium (III) and Nickel (II) Catalysts Containing Pyrazolyl/ether and Iimine/thioether Ligands for the Selective Production of Linear $\alpha$-olefins. Ph.D. Thesis, Federal University of Rio Grande do Sul, Rio Grande do Sul, Brazil, 2016.

50. Jie, S.; Zhang, S.; Sun, W.-H. 2-Arylimino-9-phenyl-1,10-phenanthrolinyl-iron, -cobalt and -nickel complexes: Synthesis, characterization and ethylene oligomerization behavior. Eur. J. Inorg. Chem. 2007, 2007, 5584-5598. [CrossRef]

51. Zhang, M.; Gao, R.; Hao, X.; Sun, W.-H. 2-Oxazoline/benzoxazole-1,10-phenanthrolinylmetal (iron, cobalt or nickel) dichloride: Synthesis, characterization and their catalytic reactivity for the ethylene oligomerization. J. Organomet. Chem. 2008, 693, 3867-3877. [CrossRef] 
52. Yang, Y.; Yang, P.; Zhang, C.; Li, G.; Yang, X.-J.; Wu, B.; Janiak, C. Synthesis, structure, and catalytic ethylene oligomerization of nickel complexes bearing 2-pyrazolyl substituted 1,10-phenanthroline ligands. J. Mol. Catal. A Chem. 2008, 296, 9-17. [CrossRef]

53. Xiao, L.; Zhang, M.; Gao, R.; Cao, X.; Sun, W.-H. 2-(1H-2-Benzimidazolyl)-6-(1-(arylimino)ethyl)pyridylnickel complexes: Synthesis, characterization, and ethylene oligomerization. Aust. J. Chem. 2010, 63, 109-115. [CrossRef]

54. Chen, X.; Zhang, L.; Liang, T.; Hao, X.; Sun, W.-H. 2-(7-methyl-1H-benzoimidazol-2-yl)-6-(1aryliminoethyl)pyridinylnickel complexes: Synthesis, characterization and their ethylene oligomerization. Comptes Rendus Chim. 2010, 13, 1450-1459. [CrossRef]

55. Chen, Y.; Hao, P.; Zuo, W.; Gao, K.; Sun, W.-H. 2-(1-Isopropyl-2-benzimidazolyl)-6-(1-aryliminoethyl)pyridyl transition metal $(\mathrm{Fe}, \mathrm{Co}$, and $\mathrm{Ni}$ ) dichlorides: Syntheses, characterizations and their catalytic behaviors toward ethylene reactivity. J. Organomet. Chem. 2008, 693, 1829-1840. [CrossRef]

56. Gao, R.; Zhang, M.; Liang, T.; Wang, F.; Sun, W.-H. Nickel(II) complexes chelated by 2-arylimino-6 -benzoxazolylpyridine: Syntheses, characterization, and ethylene oligomerization. Organometallics 2008, 27, 5641-5648. [CrossRef]

57. Adewuyi, S.; Li, G.; Zhang, S.; Wang, W.; Hao, P.; Sun, W.-H.; Tang, N.; Yi, J. Nickel(II) complexes chelated by 2-quinoxalinyl-6-iminopyridines: Synthesis, crystal structures and ethylene oligomerization. J. Organomet. Chem. 2007, 692, 3532-3541. [CrossRef]

58. Shen, M.; Hao, P.; Sun, W.-H. Synthesis, Synthesis, characterization and catalytic behaviors of neutral nickel complexes: Arylnickel N-alkyl-6-(1-(arylimino)ethyl)picolinamide. J. Organomet. Chem. 2008, 693, 1683-1695. [CrossRef]

59. Lai, J.; Hou, X.; Liu, Y.; Redshaw, C.; Sun, W.-H. 2-[1-(2,6-Dibenzhydryl-4-methylphenylimino)ethyl]-6-[1(arylimino)ethyl]pyridylnickel(II) halides: Synthesis, characterization and ethylene oligomerization behavior. J. Organomet. Chem. 2012, 702, 52-58. [CrossRef]

60. Zhang, W.; Wang, Y.; Yu, J.; Redshaw, C.; Hao, X.; Sun, W.-H. 2-(N-Alkylcarboxamide)-6-iminopyridyl palladium and nickel complexes: Coordination chemistry and catalysis. Dalton Trans. 2011, 40, 12856-12865. [CrossRef]

61. Zhang, J.; Liu, S.; Li, A.; Ye, H.; Li, Z. Nickel(II) complexes chelated by 2,6-pyridinedicarboxamide: Syntheses, characterization, and ethylene oligomerization. New J. Chem. 2016, 40, 7027-7033. [CrossRef]

62. Tayade, K.N.; Mane, M.V.; Sen, S.; Murthy, C.N.; Tembe, G.L.; Pillai, S.M.; Vanka, K.; Mukherjee, S. A catalytic and DFT study of selective ethylene oligomerization by nickel(II) oxime-based complexes. J. Mol. Catal. A Chem. 2013, 366, 238-246. [CrossRef]

63. Mukherjee, S.; Patel, B.A.; Bhaduri, S. Selective ethylene oligomerization with nickel oxime complexes. Organometallics 2009, 28, 3074-3078. [CrossRef]

64. Nyamato, G.S.; Ojwach, S.O.; Akerman, M.P. Ethylene oligomerization studies by nickel(II) complexes chelated by (amino)pyridine ligands: Experimental and density functional theory studies. Dalton Trans. 2016, 45, 3407-3416. [CrossRef]

65. Wang, K.; Shen, M.; Sun, W.-H. Synthesis, characterization and ethylene oligomerization of nickel complexes bearing N-(2-(1H-benzo[d]imidazol-2-yl)quinolin-8-yl)benzamide derivatives. Dalton Trans. 2009, 4085-4095. [CrossRef] [PubMed]

66. Wang, K.; Gao, R.; Hao, X.; Sun, W.-H. Nickel complexes bearing 2-(1H-benzo[d]imidazol-2-yl)-Nbenzylidenequinolin-8-amines: Synthesis, structure and catalytic ethylene oligomerization. Catal. Commun. 2009, 10, 1730-1733. [CrossRef]

67. Liu, H.; Zhang, L.; Chen, L.; Redshaw, C.; Li, Y.; Sun, W.-H. Synthesis, characterization and ethylene oligomerization behavior of 2-benzoimidazol-8-ethoxyquinolylnickel dihalides. Dalton Trans. 2011, 40, 2614-2621. [CrossRef] [PubMed]

68. Shi, Q.; Hao, X.; Redshaw, C.; Sun, W. Halonickel 2,4-di-t-butyl-6-(quinolin-8-yliminomethyl)phenolates: Synthesis, characterization and ethylene reactivity. Chin. J. Polym. Sci. 2013, 31, 769-777. [CrossRef]

69. Pinheiro, A.C.; Virgili, A.H.; Roisnel, T.; Kirillov, E.; Carpentier, J.F.; Casagrande, O.L. Ni(II) complexes bearing pyrrolide-imine ligands with pendant $\mathrm{N}-, \mathrm{O}$ - and S-donor groups: Synthesis, structural characterization and use in ethylene oligomerization. RSC Adv. 2015, 5, 91524-91531. [CrossRef] 
70. Boudier, A.; Breuil, P.-A.R.; Magna, L.; Olivier-Bourbigou, H.; Braunstein, P. Nickel(II) complexes with imino-imidazole chelating ligands bearing pendant donor groups ( $\mathrm{SR}, \mathrm{OR}, \mathrm{NR}_{2}, \mathrm{PR}_{2}$ ) as precatalysts in ethylene oligomerization. J. Organomet. Chem. 2012, 718, 31-37. [CrossRef]

71. Xu, C.; Shen, Q.; Sun, X.; Tang, Y. Synthesis, characterization, and highly selective ethylene dimerization to 1-butene of [O-NX]Ni(II) complexes. Chin. J. Chem. 2012, 30, 1105-1113. [CrossRef]

72. Ojwach, S.O.; Darkwa, J. Pyrazole and (pyrazol-1-yl)metal complexes as carbon-carbon coupling catalysts. Inorg. Chim. Acta 2010, 363, 1947-1964. [CrossRef]

73. Gafurov, Z.N.; Bekmukhamedov, G.E.; Kagilev, A.A.; Kantyukov, A.O.; Sakhapov, I.F.; Mikhailov, I.K.; Khayarov, K.R.; Zaripov, R.B.; Islamov, D.R.; Usachev, K.S.; et al. Unsymmetrical pyrazole-based PCN pincer $\mathrm{Ni}^{\mathrm{II}}$ halides: Reactivity and catalytic activity in ethylene oligomerization. J. Organomet. Chem. 2020, 912, 121163. [CrossRef]

74. Ainooson, M.K.; Guzei, I.A.; Spencer, L.C.; Darkwa, J. Pyrazolylimine iron and cobalt, and pyrazolylamine nickel complexes: Synthesis and evaluation of nickel complexes as ethylene oligomerization catalysts. Polyhedron. 2013, 53, 295-303. [CrossRef]

75. Ulbrich, A.H.D.P.S.; Campedelli, R.R.; Milani, J.L.S.; dos Santos, J.H.Z.; Casagrande, O.D.L. Nickel catalysts based on phenyl ether-pyrazol ligands: Synthesis, XPS study, and use in ethylene oligomerization. Appl. Catal. A 2013, 453, 280-286. [CrossRef]

76. Dresch, L.C.; de Araújo, B.B.; Casagrande, O.D.L.; Stieler, R. A novel class of nickel(II) complexes containing selenium-based bidentate ligands applied in ethylene oligomerization. RSC Adv. 2016, 6, 104338-104344. [CrossRef]

77. Ajellal, N.; Kuhn, M.C.A.; Boff, A.D.G.; Hörner, M.; Thomas, C.M.; Carpentier, J.-F.; Casagrande, O.L. Nickel complexes based on tridentate pyrazolyl ligands for highly efficient dimerization of ethylene to 1-butene. Organometallics 2006, 25, 1213-1216. [CrossRef]

78. de Oliveira, L.; Campedelli, R.; Bergamo, A.; Santos, A.; Casagrande, O. Substituted tridentate pyrazolyl ligands for chromium and nickel-catalyzed ethylene oligomerization reactions. Effect of auxiliary ligand on activity and selectivity. J. Braz. Chem. Soc. 2010, 21, 1318-1328. [CrossRef]

79. de Oliveira, L.L.; Campedelli, R.R.; Kuhn, M.C.A.; Carpentier, J.-F.; Casagrande, O.L. Highly selective nickel catalysts for ethylene oligomerization based on tridentate pyrazolyl ligands. J. Mol. Catal. A Chem. 2008, 288, 58-62. [CrossRef]

80. Tuskaev, V.A.; Zubkevic, S.V.; Saracheno, D.; Gagieva, S.C.; Dorovatovskii, P.V.; Kononova, E.G.; Khrustalev, V.N.; Zarubin, D.N.; Bulychev, B.M.; Kissin, Y.V. Nickel(II) complexes with tripodal NNN ligands as homogenous and supported catalysts for ethylene oligomerization. Mol. Catal. 2019, 464, $29-38$. [CrossRef]

81. Ulbrich, A.H.D.P.S.; Bergamo, A.L.; Casagrande, O.D.L. Oligomerization of ethylene using tridentate nickel catalysts bearing ether-pyrazol ligands with pendant O- and S-donor groups. Catal. Commun. 2011, 16, 245-249. [CrossRef]

82. Dresch, L.C.; Junges, C.H.; Casagrande, O.D.L.; Stieler, R. Nickel complexes supported by selenium-based tridentate ligands and their use as effective catalyst systems for ethylene dimerisation. J. Organomet. Chem. 2018, 856, 34-40. [CrossRef]

83. Nyamato, G.S.; Alam, M.G.; Ojwach, S.O.; Akerman, M.P. Nickel(II) complexes bearing pyrazolylpyridines: Synthesis, structures and ethylene oligomerization reactions. Appl. Organomet. Chem. 2016, 30, 89-94. [CrossRef]

84. Nyamato, G.S.; Alam, M.G.; Ojwach, S.O.; Akerman, M.P. (Pyrazolyl)-(phosphinoyl)pyridine iron(II), cobalt(II) and nickel(II) complexes: Synthesis, characterization and ethylene oligomerization studies. J. Organomet. Chem. 2015, 783, 64-72. [CrossRef]

85. Junges, C.H.; Dresch, L.C.; da Costa, M.T.; Tirloni, B.; Casagrande, O.L., Jr.; Stieler, R. Pyrazolyl-phosphinoyl nickel (II) complexes: Synthesis, characterization and ethylene dimerization studies. Appl. Organomet. Chem. 2019, 33, e4887. [CrossRef]

86. Zubkevich, S.V.; Tuskaev, V.A.; Gagieva, S.C.; Pavlov, A.A.; Khrustalev, V.N.; Zarubin, D.N.; Kurmaev, D.A.; Kolosov, N.A.; Bulychev, B.M. Molecular structure, magnetic properties and catalytic activity in selective ethylene dimerization of nickel (II) complexes with bis(3,5-dimethylpyrazol-1-yl)methane. J. Mol. Struct. 2020, 1206, 127692. [CrossRef] 
87. Wang, T.; Dong, B.; Chen, Y.-H.; Mao, G.-L.; Jiang, T. Nickel complexes incorporating pyrazole-based ligands for ethylene dimerization to 1-butylene. J. Organomet. Chem. 2015, 798, 388-392. [CrossRef]

88. Zubkevich, S.V.; Gagieva, S.C.; Tuskaev, V.A.; Dorovatovskii, P.V.; Khrustalev, V.N.; Sizov, A.I.; Bulychev, B.M. Synthesis and reactivity in ethylene oligomerization by heteroscorpionate dibromonickel(II) complexes. Inorg. Chim. Acta 2017, 458, 58-67. [CrossRef]

89. Ulbrich, A.H.D.P.S.; Milani, J.L.S.; Roisnel, T.; Carpentier, J.-F.; Casagrande, O.L. Zwitterionic Ni(II) complexes bearing pyrazolyl-ether-imidazolium ligands: Synthesis, structural characterization and use in ethylene oligomerization. New J. Chem. 2015, 39, 7234-7242. [CrossRef]

90. Cabrera, A.R.; Martinez, I.; Daniliuc, C.G.; Galland, G.B.; Salas, C.O.; Rojas, R.S. New air stable cationic methallyl Ni complexes bearing imidoyl-indazole carboxylate ligand: Synthesis, characterization and their reactivity towards ethylene. J. Mol. Catal. A Chem. 2016, 414, 19-26. [CrossRef]

91. Espinet, P.; Soulantica, K. Phosphine-pyridyl and related ligands in synthesis and catalysis. Coord. Chem. Rev. 1999, 193-195, 499-556. [CrossRef]

92. Braunstein, P.; Naud, F. Hemilability of hybrid ligands and the coordination chemistry of oxazoline-based systems. Angew Chem. Int. Ed. 2001, 40, 680-699. [CrossRef]

93. Flapper, J.; Kooijman, H.; Lutz, M.; Spek, A.L.; van Leeuwen, P.W.N.M.; Elsevier, C.J.; Kamer, P.C.J. Nickel and palladium complexes of pyridine-phosphine ligands as ethene oligomerization catalysts. Organometallics 2009, 28, 1180-1192. [CrossRef]

94. Freixa, Z.; van Leeuwen, P.W.N.M. Bite angle effects in diphosphine metal catalysts: Steric or electronic? Dalton Trans. 2003, 10, 1890-1901. [CrossRef]

95. van Leeuwen, P.W.N.M.; Kamer, P.C.J.; Reek, J.N.H.; Dierkes, P. Ligand bite angle effects in metal-catalyzed C-C bond formation. Chem. Rev. 2000, 100, 2741-2770. [CrossRef] [PubMed]

96. Flapper, J.; Kooijman, H.; Lutz, M.; Spek, A.L.; van Leeuwen, P.W.N.M.; Elsevier, C.J.; Kamer, P.C.J. Nickel and palladium complexes of new pyridine-phosphine ligands and their use in ethene oligomerization. Organometallics 2009, 28, 3272-3281. [CrossRef]

97. Kermagoret, A.; Braunstein, P. Mono- and dinuclear nickel complexes with phosphino-, phosphinito-, and phosphonitopyridine ligands: Synthesis, structures, and catalytic oligomerization of ethylene. Organometallics 2008, 27, 88-99. [CrossRef]

98. Flapper, J.; van Leeuwen, P.W.N.M.; Elsevier, C.J.; Kamer, P.C.J. Nickel and palladium complexes of pyridine-phosphine ligands bearing aromatic substituents and their behavior as catalysts in ethene oligomerization. Organometallics 2009, 28, 3264-3271. [CrossRef]

99. Yang, Q.-Z.; Kermagoret, A.; Agostinho, M.; Siri, O.; Braunstein, P. Nickel complexes with functional zwitterionic N,O-benzoquinonemonoimine-type ligands: Syntheses, structures, and catalytic oligomerization of ethylene. Organometallics 2006, 25, 5518-5527. [CrossRef]

100. Chavez, P.; Rios, I.G.; Kermagoret, A.; Pattacini, R.; Meli, A.; Bianchini, C.; Giambastiani, G.; Braunstein, P. Nickel complexes with phosphinito-oxazoline ligands: Temperature-controlled formation of mono- or dinuclear complexes and catalytic oligomerization of ethylene and propylene. Organometallics 2009, 28, 1776-1784. [CrossRef]

101. Kermagoret, A.; Tomicki, F.; Braunstein, P. Nickel and iron complexes with N,P,N-type ligands: Synthesis, structure and catalytic oligomerization of ethylene. Dalton Trans. 2008, 2945-2955. [CrossRef]

102. Dyer, P.W.; Fawcett, J.; Hanton, M.J. Rigid N-phosphino guanidine P,N ligands and their use in nickel-catalyzed ethylene oligomerization. Organometallics 2008, 27, 5082-5087. [CrossRef]

103. de Souza, R.; Bernardo-Gusmão, K.; Cunha, G.A.; Loup, C.; Leca, F.; Réau, R. Ethylene dimerization into 1-butene using 2-pyridylphosphole nickel catalysts. J. Catal. 2004, 226, 235-239. [CrossRef]

104. de la Tabla, L.O.; Matas, I.; Palma, P.; Álvarez, E.; Cámpora, J. Nickel and palladium complexes with new phosphinito-imine ligands and their application as ethylene oligomerization catalysts. Organometallics 2012, 31, 1006-1016. [CrossRef] 
105. Daugulis, O.; Brookhart, M. Polymerization of ethylene with cationic palladium and nickel catalysts containing bulky nonenolizable imine-phosphine ligands. Organometallics 2002, 21, 5926-5934. [CrossRef]

106. Buchard, A.; Auffrant, A.; Klemps, C.; Vu-Do, L.; Boubekeur, L.; Goff, X.F.L.; Floch, P.L. Highly efficient P-N nickel(II) complexes for the dimerisation of ethylene. Chem. Commun. 2007, 1502-1504. [CrossRef] [PubMed]

107. Cheisson, T.; Cao, T.-P.-A.; Le Goff, X.F.; Auffrant, A. Nickel complexes featuring iminophosphorane-phenoxide ligands for catalytic ethylene dimerization. Organometallics. 2014, 33, 6193-6199. [CrossRef]

108. Peulecke, N.; Yakhvarov, D.G.; Heinicke, J.W. Chemistry of $\alpha$-phosphanyl $\alpha$-amino acids. Eur. J. Inorg. Chem. 2019, 1507-1518. [CrossRef]

109. Ghalib, M.; Lach, J.; Fomina, O.S.; Yakhvarov, D.G.; Jones, P.G.; Heinicke, J. Benzazaphospholine-2-carboxylic acids: Synthesis, structure and properties of heterocyclic phosphanyl amino acids. Polyhedron 2014, 77, 10-16. [CrossRef]

110. Basvani, K.R.; Fomina, O.S.; Yakhvarov, D.G.; Heinicke, J. Synthesis and properties of zwitterionic phosphonioglycolates. Polyhedron 2014, 67, 306-313. [CrossRef]

111. Soficheva, O.S.; Bekmukhamedov, G.E.; Dobrynin, A.B.; Heinicke, J.W.; Sinyashin, O.G.; Yakhvarov, D.G. $\alpha$-Diphenylphosphino-N-(pyrazin-2-yl)glycine as a ligand in Ni-catalyzed ethylene oligomerization. Mendeleev Commun. 2019, 29, 575-577. [CrossRef]

112. Appleby, T.; Woollins, J.D. Inorganic backbone phosphines. Coord. Chem. Rev. 2002, 235, 121-140. [CrossRef]

113. Alferov, K.A.; Belov, G.P.; Meng, Y. Chromium catalysts for selective ethylene oligomerization to 1-hexene and 1-octene: Recent results. Appl. Catal. A 2017, 542, 71-124. [CrossRef]

114. Song, K.; Gao, H.; Liu, F.; Pan, J.; Guo, L.; Zai, S.; Wu, Q. Syntheses, structures, and catalytic ethylene oligomerization behaviors of bis(phosphanyl)aminenickel(II) complexes containing $\mathrm{N}$-functionalized pendant groups. Eur. J. Inorg. Chem. 2009, 2009, 3016-3024. [CrossRef]

115. Ghisolfi, A.; Fliedel, C.; Rosa, V.; Monakhov, K.Y.; Braunstein, P. Combined experimental and theoretical study of bis(diphenylphosphino)(N-thioether)amine-type ligands in nickel(II) complexes for catalytic ethylene oligomerization. Organometallics 2014, 33, 2523-2534. [CrossRef]

116. Meng, X.; Zhang, L.; Chen, Y.; Jiang, T. Silane-bridged diphosphine ligands for nickel-catalyzed ethylene oligomerization. React. Kinet. Mech. Catal. 2016, 119, 481-490. [CrossRef]

117. Wei, W.; Yu, B.; Alam, F.; Huang, Y.; Cheng, S.; Jiang, T. Ethylene oligomerization promoted by nickel-based catalysts with silicon-bridged diphosphine amine ligands. Transition Met. Chem. 2019, 44, 125-133. [CrossRef]

118. Bekmukhamedov, G.E.; Sukhov, A.V.; Kuchkaev, A.M.; Khayarov, K.R.; Gerasimov, A.V.; Vasilenko, I.V.; Kostjuk, S.V.; Yakhvarov, D.G. Electrochemical synthesis of zirconium pre-catalysts for homogeneous ethylene oligomerization. Catalysts 2019, 9, 1059. [CrossRef]

119. Boulens, P.; Lutz, M.; Jeanneau, E.; Olivier-Bourbigou, H.; Reek, J.N.H.; Breuil, P.-A.R. Iminobisphosphines to (non-)symmetrical diphosphinoamine ligands: Metal-induced synthesis of diphosphorus nickel complexes and application in ethylene oligomerisation reactions. Eur. J. Inorg. Chem. 2014, 2014, 3754-3762. [CrossRef]

120. Dierkes, P.; van Leeuwen, P.W.N.M. The bite angle makes the difference: A practical ligand parameter for diphosphine ligands. J. Chem. Soc. Dalton Trans. 1999, 1519-1530. [CrossRef]

121. Mora, G.; van Zutphen, S.; Klemps, C.; Ricard, L.; Jean, Y.; Le Floch, P. Synthesis, X-ray, and electronic structures of a new nickel dibromide complex. Activity in the regioselective catalyzed dimerization of ethylene into 1-butene. Inorg. Chem. 2007, 46, 10365-10371. [CrossRef]

122. Boulens, P.; Pellier, E.; Jeanneau, E.; Reek, J.N.H.; Olivier-Bourbigou, H.; Breuil, P.-A.R. Self-assembled organometallic nickel complexes as catalysts for selective dimerization of ethylene into 1-butene. Organometallics 2015, 34, 1139-1142. [CrossRef]

123. Lhermet, R.; Moser, E.; Jeanneau, E.; Olivier-Bourbigou, H.; Breuil, P.-A.R. Outer-sphere reactivity shift of secondary phosphine oxide-based nickel complexes: From ethylene hydrophosphinylation to oligomerization. Chem. Eur. J. 2017, 23, 7433-7437. [CrossRef]

124. Lejeune, M.; Sémeril, D.; Jeunesse, C.; Matt, D.; Peruch, F.; Lutz, P.J.; Ricard, L. Diphosphines with expandable bite angles: Highly active ethylene dimerisation catalysts based on upper rim, distally diphosphinated calix[4]arenes. Chem. Eur. J. 2004, 10, 5354-5360. [CrossRef]

125. Liddle, S.T.; Edworthy, I.S.; Arnold, P.L. Anionic tethered N-heterocyclic carbene chemistry. Chem. Soc. Rev. 2007, 36, 1732-1744. [CrossRef] [PubMed] 
126. Cavell, K.J.; McGuinness, D.S. Redox processes involving hydrocarbylmetal (N-heterocyclic carbene) complexes and associated imidazolium salts: Ramifications for catalysis. Coord. Chem. Rev. 2004, 248, 671-681. [CrossRef]

127. McGuinness, D.S.; Mueller, W.; Wasserscheid, P.; Cavell, K.J.; Skelton, B.W.; White, A.H.; Englert, U. Nickel(II) heterocyclic carbene complexes as catalysts for olefin dimerization in an imidazolium chloroaluminate ionic liquid. Organometallics 2002, 21, 175-181. [CrossRef]

128. Prakasham, A.P.; Ghosh, P. Nickel N-heterocyclic carbene complexes and their utility in homogeneous catalysis. Inorg. Chim. Acta 2014, 431, 61-100. [CrossRef]

129. Li, W.-F.; Sun, H.-M.; Chen, M.-Z.; Shen, Q.; Zhang, Y. Synthesis and catalytic activity of neutral salicylaldiminato nickel(II) complexes bearing a single N-heterocyclic carbene ligand. J. Organomet. Chem. 2008, 693, 2047-2051. [CrossRef]

130. McGuinness, D.S.; Cavell, K.J.; Skelton, B.W.; White, A.H. Zerovalent palladium and nickel complexes of heterocyclic carbenes: Oxidative addition of organic halides, carbon-carbon coupling processes, and the Heck reaction. Organometallics 1999, 18, 1596-1605. [CrossRef]

131. Hameury, S.; de Frémont, P.; Breuil, P.-A.R.; Olivier-Bourbigou, H.; Braunstein, P. Bis(ether-functionalized $\mathrm{NHC}$ ) nickel(II) complexes, trans to cis isomerization triggered by water coordination, and catalytic ethylene oligomerization. Organometallics 2014, 34, 2183-2201. [CrossRef]

132. Ren, X.; Wesolek, M.; Bailly, C.; Karmazin, L.; Braunstein, P. Silver(I) and nickel(II) complexes with oxygenor nitrogen functionalized NHC ditopic ligands and catalytic ethylene oligomerization. Eur. J. Inorg. Chem. 2020, 1073-1087. [CrossRef]

133. Kermagoret, A.; Braunstein, P. Synthesis of nickel complexes with bidentate N,O-type ligands and application in the catalytic oligomerization of ethylene. Dalton Trans. 2008, 1564-1573. [CrossRef]

134. Speiser, F.; Braunstein, P.; Saussine, L. Dinuclear nickel complexes with bidentate N,O ligands: Synthesis, structure, and catalytic oligomerization of ethylene. Inorg. Chem. 2004, 43, 4234-4240. [CrossRef]

135. Swarts, A.J.; Mapolie, S.F. The synthesis and application of novel Ni(II) N-alkyl dipyridylaldiminato complexes as selective ethylene oligomerisation catalysts. Dalton Trans. 2014, 43, 9892-9900. [CrossRef] [PubMed]

136. Majoumo-Mbe, F.; Lönnecke, P.; Volkis, V.; Sharma, M.; Eisen, M.S.; Hey-Hawkins, E. Oligomerization of $\alpha$-olefins by the dimeric nickel bisamido complex $\left[\mathrm{Ni}\left\{1-\mathrm{N}\left(\mathrm{PMes}_{2}\right)-2-\mathrm{N}\left(\mu-\mathrm{PMes}_{2}\right) \mathrm{C}_{6} \mathrm{H}_{4}-\mathrm{k}^{3} \mathrm{~N}, \mathrm{~N}^{\prime}, \mathrm{P}-\mathrm{k}^{1} \mathrm{P}^{\prime}\right\}\right]_{2}$ activated by methylalumoxane (MAO). J. Organomet. Chem. 2008, 693, 2603-2609. [CrossRef]

137. Zhang, S.; Sun, W.-H.; Kuang, X.; Vystorop, I.; Yi, J. Unsymmetric bimetal(II) complexes: Synthesis, structures and catalytic behaviors toward ethylene. J. Organomet. Chem. 2007, 692, 5307-5316. [CrossRef]

138. Wang, K.; Shen, M.; Sun, W.-H. N-(Pyridin-2-yl)picolinamide tetranickel clusters: Synthesis, structure and ethylene oligomerization. Polyhedron 2010, 29, 564-568. [CrossRef]

139. Zhang, N.; Wang, J.; Huo, H.; Chen, L.; Shi, W.; Li, C.; Wang, J. Iron, cobalt and nickel complexes bearing hyperbranched iminopyridyl ligands: Synthesis, characterization and evaluation as ethylene oligomerization catalysts. Inorg. Chim. Acta. 2018, 469, 209-216. [CrossRef]

140. Chen, L.; Huo, H.; Wang, L.; Kuang, Q.; Shi, W.; Zhang, N.; Li, Z.; Wang, J. Ethylene oligomerization studies utilizing nickel complexes bearing pyridine-imine ligands. Inorg. Chim. Acta 2019, 491, 67-75. [CrossRef]

141. Chen, L.; Ma, L.; Jiang, Y.; Liu, J.; Li, C.; Zhang, N.; Wang, J. Synthesis and characterization of iron, cobalt and nickel complexes bearing para-phenylene-linked pyridine imine ligand and their catalytic properties for ethyleneoligomerization. Polym. Bull. 2020. [CrossRef]

142. Velthoen, M.E.Z.; Boereboom, J.M.; Bulo, R.E.; Weckhuysen, B.M. Insights into the activation of silica-supported metallocene olefin polymerization catalysts by methylaluminoxane. Catal. Today. 2019, 334, 223-230. [CrossRef]

143. Velthoen, M.E.Z.; Muñoz-Murillo, A.; Bouhmadi, A.; Cecius, M.; Diefenbach, S.; Weckhuysen, B.M. The multifaceted role of methylaluminoxane in metallocene-based olefin polymerization catalysis. Macromolecules 2018, 51, 343-355. [CrossRef]

144. Hirvi, J.T.; Bochmann, M.; Severn, J.R.; Linnolahti, M. Formation of octameric methylaluminoxanes by hydrolysis of trimethylaluminum and the mechanisms of catalyst activation in single-site $\alpha$-olefin polymerization catalysis. ChemPhysChem 2014, 15, 2732-2742. [CrossRef] 
145. McGuinness, D.S. Olefin oligomerization via metallacycles: Dimerization, trimerization, tetramerization, and beyond. Chem. Rev. 2011, 111, 2321-2341. [CrossRef] [PubMed]

146. Shmidt, R. Catalytic Compositions for Dimerization of Ethylene. Russian Patent 2,647,726, 3 December 2014.

(C) 2020 by the authors. Licensee MDPI, Basel, Switzerland. This article is an open access article distributed under the terms and conditions of the Creative Commons Attribution (CC BY) license (http://creativecommons.org/licenses/by/4.0/). 